BNL- 65339

Informal Report

\title{
Risk Assessment and Optimization (ALARA) Analysis for the Environmental Remediation of Brookhaven National Laboratory's Hazardous Waste Management Facility
}

March 1998

Prepared by

Bruce J. Dionne, Samuel C. Morris III, John W. Baum, and Paul D. Moskowitz

Brookhaven National Laboratory

Upton, New York 11973-5000

Steven Masciulli

ABB Combustion Engineering, Inc.

Site Remediation Services Department

2000 Day Hill Road

Windsor, CT 06095

and

Charley Yu

Argonne National Laboratory

Environmental Assessment Division

9700 South Cass Avenue

Argonne, IL 60439

${ }^{\text {aW }}$ ork performed under Contract No. DE-AC-02-98CH10886 with the U.S. Department of Energy. 


\section{DISCLAIMER}

This report was prepared as an account of work sponsored by an agency of the United States Government. Neither the United States Government nor any agency thereof, nor any of their employees, makes any warranty, express or implied, or assumes any legal liability or responsibility for the accuracy, completeness, or usefulness of any information, apparatus, product, or process disclosed, or represents that its use would not infringe privately owned rights. Reference herein to any specific commercial product, process, or service by trade name, trademark, manufacturer, or otherwise does not necessarily constitute or imply its endorsement, recommendation, or favoring by the United States Government or any agency thereof. The views and opinions of authors expressed herein do not necessarily state or reflect those of the United States Government or any agency thereof. 


\section{DISCLAIMER}

Portions of this document may be illegible electronic image products. Images are produced from the best available original document. 


\begin{abstract}
The Department of Energy's (DOE) Office of Environment, Safety, and Health (EH) sought examples of risk-based approaches to environmental restoration to include in their guidance for DOE nuclear facilities. Extensive measurements of radiological contamination in soil and groundwater have been made at Brookhaven National Laboratory's Hazardous Waste Management Facility (HWMF) as part of a Comprehensive Environmental Response, Compensation and Liability Act (CERCLA) remediation process. This provided an ideal opportunity for a case study. This report provides a risk assessment and an "As Low as Reasonably Achievable" (ALARA) analysis for use at other DOE nuclear facilities as an example of a risk-based decision technique.

Although this analysis uses data obtained through the CERCLA process, it was conducted separately from that process. CERCLA requires that many factors in addition to risk be considered in determining remediation goals and the remedial action. At the time of this writing a final decision had not yet been made on the remediation goals or remedial action for the HWMF. It seemed clear, however, that, although open space would be the most probable future land use for the HWMF, remediation goals would be based upon a more stringent land use scenario, namely commercial-industrial. This was selected to provide additional protection to the public and environment.
\end{abstract}

The objective of deriving the optimal soil remediation goal was to protect human health and the environment from the radiological risks, minimize the impact on workers, the public, and the ecosystem from the remediation, and keep its costs at a reasonable level. This report describes (1) the assessment of the radiological risks to be averted to both workers and the public, (2) the assessment of radiological risks to a suburban resident, assuming the failure of active controls, i.e., zoning restrictions, (3) the assessment of radiological risks to a suburban resident from drinking groundwater that could become contaminated from infiltration of residual radioactive material in the soil, (4) the estimation of the value of radiological and non-radiological risks, as well as other damages, to be avoided by the remedial actions, and (5) the comparison of the monetary values of these reduced risks/damages with the costs of the remedial actions at several risk levels below the legal limit.

The selection of the optimal remediation goal was accomplished by first establishing risk-based levels below those needed to comply with the applicable or relevant and appropriate federal, state, and local requirements. This assessment/analysis complied with the applicable requirements and associated guidance of DOE 5400.5 and 40 CFR Part 300 . Next, the selection was made by balancing the value of the estimated radiogenic effects and other impacts to be averted against the cost for excavating and disposing of the contaminated soil off-site. 
Above the $100 \mathrm{mrem} / \mathrm{yr}$ public dose limit, DOE must expend whatever is needed to comply with these Federal regulations. The results of the ALARA analysis showed that below the $100 \mathrm{mrem} / \mathrm{yr}$ limit, there was no positive net benefit derived from the excavation and offsite disposal of soil contaminated with radioactive material. The ALARA level selected for this analysis was the level at which the costs to remediate and the net fatalities begin to increase dramatically.

This occurred at the $15 \mathrm{mrem} / \mathrm{yr}$ level for the soil concentration distribution at BNL's Hazardous Waste Management Facility; it corresponded to $230 \mathrm{pCi} / \mathrm{g}$ for cesium137 assuming an open-space land use and the 50 years of Federal control at BNL. The preliminary remediation guideline that was proposed by DOE to the State and Federal regulators was $67 \mathrm{pCi} / \mathrm{g}$ (cesium-137). This guideline was based on a commercial industrial land use and 50 years of control. Therefore, the $67 \mathrm{pCi} / \mathrm{g}$ preliminary remediation guideline being proposed for the HWMF was more protective for the hypothetical future user than the level derived in this report using risk-based decision techniques.

The corresponding derived concentration guideline for strontium-90 was 5,800 $\mathrm{pCi} / \mathrm{g}$ using risk-based decision techniques. An alternate analysis was performed to derive a soil to water cleanup guideline for strontium-90 that would assure protection of groundwater. This was needed since strontium-90 leaches more quickly through the soil than cesium-137 and thus must also be controlled to protect the sole-source aquifer. The value of the alternate derived concentration guideline to demonstrate compliance with the maximum concentration level in the EPA's Primary Drinking-Water Regulation was 45 $\mathrm{pCi} / \mathrm{g}$ for strontium-90. As was the case with cesium-137, the preliminary remediation guideline that was proposed by $\mathrm{DOE}$ to the State and Federal regulators for strontium-90 was lower, in this case $15 \mathrm{pCi} / \mathrm{g}$. Therefore, the $15 \mathrm{pCi} / \mathrm{g}$ preliminary remediation guideline for the HWMF was more protective for the hypothetical future user than the level derived in this report using risk-based decision techniques.

These lower remediation guidelines will result in an additional $\$ 10$ million being expended to remediate to the level that is expected to be selected by the State and Federal regulators. The benefits from these lower guidelines include reduction in risk to future visitors, in risk to potential residents if active controls fail, in residual radioactive material in soil, and in radioactive leachate that could contaminate the sole-source aquifer. 


\section{EXECUTIVE SUMMARY}

The Department of Energy's (DOE) Office of Environment, Safety, and Health (EH412) sought examples of risk-based approaches to environmental restoration to include in their guidance for DOE nuclear facilities. Extensive measurements of radiological contamination in soil and groundwater have been made at Brookhaven National Laboratory's Hazardous Waste Management Facility (HWMF) as part of a Comprehensive Environmental Response, Compensation and Liability Act (CERCLA) remediation process. This provided an ideal opportunity for a case study. This report provides a risk assessment and an "As Low as Reasonably Achievable" (ALARA) analysis for use at other DOE nuclear facilities as an example of a risk-based decision technique.

This ALARA or risk optimization analysis was undertaken in accordance with the applicable requirements (USDOE 1991b \& USEPA 1988b) and DOE guidance (USDOE 1991a \& 1997). It also was consistent, to the extent possible, with the relevant and appropriate requirements in 10 CFR Part 20, Subpart E, as well as the potential requirements in the available versions of proposed 10 CFR Part 834 (USDOE 1993), and draft 40 CFR Part 196 (withdrawn by EPA on December 19, 1996)

The results from the risk assessments and the optimization (ALARA) analysis can be used by decision-makers as input to the selection of the optimum risk-based remediation level. It also can be used to make an informed risk-management decision as to the most appropriate remedial alternative. These methods may also be of value for risk assessors and decisionmakers at the 5,000 estimated sites in the United States that are contaminated with radioactive materials; 250 of these sites belong to Federal agencies, primarily DOE and the Department of Defense (DOD) (Wolbarst 1996).

For more than 20 years, BNL's HWMF has been the facility for processing, limited treatment, and storage of radioactive and hazardous waste. Operations are now being terminated and the work plan for facility remediation is being developed. A Feasibility Study was conducted in 1996 (CDM 1996b). The remedy selected in this draft report was largescale excavation with off-site disposal. This involved excavating $30,800 \mathrm{yd}^{3}\left(24,000 \mathrm{~m}^{3}\right)$ in order to achieve the preliminary remediation goal of $67 \mathrm{pCi} / \mathrm{g}$ for cesium-137. This cleanup goal was based on a $15 \mathrm{mrem} / \mathrm{yr}$ dose goal using a commercial industrial scenario and 50 years of Federal control.

In this risk assessment/optimization analysis, the derived concentration guideline limits (DCGLs) were based on a range of cleanup goals from $1 \mathrm{mrem} / \mathrm{yr}$ to $100 \mathrm{mrem} / \mathrm{yr}$ using an open-space scenario and 50 years of Federal control. Approximately, 8,000 $\mathrm{yd}^{3}$ to $78,000 \mathrm{yd}^{3}$ $\left(6,000\right.$ to $\left.60,000 \mathrm{~m}^{3}\right)$ of contaminated soil would require excavation in order to achieve the corresponding DCGLs of $15 \mathrm{pCi} / \mathrm{g}$ to $1,500 \mathrm{pCi} / \mathrm{g}$. The remedy in the attached report assumed packaging it into B-25 steel containers, storing them temporally at the new HWMF, 
and transporting and disposing of the low-level waste at the Envirocare disposal site in Clive, Utah, and the stabilized waste at the Fluor Daniels disposal site in Richland, Washington. This report estimated the risks averted to the workers and members of the public from the assumed remedy.

Results of Risk Assessment

Dose assessments were made for workers and the public to determine the risk to be averted from this proposed remedial action using the risk-based remediation goals of 1,15 , 25,75 , and the $100 \mathrm{mrem} / \mathrm{yr}$ limit. These goals and limit translated into the DCGLs listed in Table E-1. These DCGLs were based on an undeveloped open-space scenario and 50 years of federal control. The clean-up of soil to these DCGL levels required that the following soil volumes be excavated $78,000 \mathrm{yd}^{3}\left(60,000 \mathrm{~m}^{3}\right) ; 26,000 \mathrm{yd}^{3}\left(20,000 \mathrm{~m}^{3}\right) ; 20,000 \mathrm{yd}^{3}\left(15,000 \mathrm{~m}^{3}\right)$; $9,000 \mathrm{yd}^{3}\left(7,000 \mathrm{~m}^{3}\right)$; and $8,000\left(6,100 \mathrm{~m}^{3}\right) \mathrm{yd}^{3}$, respectively.

Table E-1. Derived Concentration Guideline Limits (DCGL) for the Undeveloped Open-Space Scenario after 50 Years of Federal Control

\begin{tabular}{|c|c|c|}
\hline $\begin{array}{c}\text { Risk-Based Remediation } \\
\text { Goals/Limit } \\
\text { (mrem/yr) }\end{array}$ & $\begin{array}{c}\text { DCGL } \\
\text { Cesium-137 } \\
\text { (pCi/g) }\end{array}$ & $\begin{array}{c}\text { DCGL } \\
\text { Strontium-90 } \\
\text { (pCi/g) }\end{array}$ \\
\hline \hline 1 & 15 & 390 \\
\hline 15 & 230 & 5,800 \\
\hline 25 & 380 & 10,000 \\
\hline 75 & 1,140 & 29,000 \\
\hline 100 & 1,500 & 39,000 \\
\hline
\end{tabular}

Radiological risk assessments were performed for the following: present workers, future members of the public, a basement resident assuming the failure of active controls, and a resident from drinking groundwater. The estimated range of collective doses for present workers, over the remediation goal/limit range of 1 to $100 \mathrm{mrem} / \mathrm{yr}$, are summarized below. The potential radiation doses to workers resulting from excavation and off-site disposal (collective dose impacts) would be extremely large in comparison to the potential radiation dose that would be saved by present workers as a result of remediation(collective dose savings).

- Worker collective dose savings from remediation: 4.1 to 3.8 person-rem

- Worker collective dose impacts from remediation: -223 to -212 person-rem

- Net collective dose to workers: -219 to -208 person-rem

The estimated range of collective doses for the future public, over the remediation goal/limit range of 1 to $100 \mathrm{mrem} / \mathrm{yr}$, are summarized below. The potential radiation doses to 
the public resulting from excavation and off-site disposal (collective dose impacts) would be about three times greater than the potential radiation dose that would be avoided by remediation (net collective dose). The radiological impacts to the public from the remediation (dose impacts from remediation) would be comparable to the dose that would be saved (dose savings from remediation). Workers would receive about 100 times more collective dose than what would be averted to the public.

- Public collective dose savings from remediation: 8.5 to 8.1 person-rem

- Public collective dose impacts from remediation: -6.7 to -6.3 person-rem

- Net collective dose to public: 1.8 to 1.8 person-rem

The Nuclear Regulatory Commission's (NRC) 10 CFR Part 20 (USNRC 1997) contains requirements to assess potential doses under restricted-use scenarios assuming that the restrictions fail. An analysis was conducted to estimate the dose to a resident, assuming the failure of active controls and to establish alternate derived concentration guidelines. The alternate derived concentration guideline for strontium-90 that was equivalent to the 75 mrem/yr criterion was more restrictive than that based on the $15 \mathrm{mrem} / \mathrm{yr}$ EPA's proposed criterion ( $300 \mathrm{pCi} / \mathrm{g}$ vs. $5,800 \mathrm{pCi} / \mathrm{g}$ ). Therefore, the strontium-90 alternate derived concentration guideline for the loss of active controls should be considered in selecting the final remediation goal.

The draft EPA 40 CFR Part 196 contained a requirement to determine if the maximum concentration level in the Primary Drinking Water Regulations would be exceeded now or in the future. An analysis was conducted to derive the residual radionuclide concentration in soil so that the dose to a resident from drinking groundwater would not be expected to exceed EPA's safe drinking-water standard over the next 1,000 years. However, this alternate derived concentration guideline for strontium- 90 was more restrictive than that based on the $15 \mathrm{mrem} / \mathrm{yr}$ EPA's proposed criterion ( $45 \mathrm{pCi} / \mathrm{g}$ vs. $5,800 \mathrm{pCi} / \mathrm{g}$ ). Therefore, the strontium-90 alternate derived concentration guideline for demonstrating compliance with EPA's Primary Drinking-Water Regulation should be considered in selecting the final remediation goal.

Next, the hypothetical fatalities for workers and public from radiological causes, as well as those that could result from construction, and transportation at the various remediation goals are summarized in Table E-2. They show that the net risk of fatalities associated with remediation range from 15 in 100 to 9 in 100 for the remediation goal/limit of 1 and 100 mrem/yr, respectively. Therefore, the probability for a hypothetical fatality resulting from the remedial actions ( 0.09 to 0.15 hypothetical fatalities) is higher than that for the no-action alternative ( 0.0001 to 0.0043 hypothetical fatalities). 
Table E-2 Estimated Hypothetical Fatalities Associated with Remediation

\begin{tabular}{|c|c|c|c|c|c|}
\hline $\begin{array}{c}\text { Risk-based } \\
\text { Remediation } \\
\text { Goals/Limit } \\
\text { (mrem/yr) }\end{array}$ & $\begin{array}{c}\text { Net Worker } \\
\text { Radiation } \\
\text { Fatalities }\end{array}$ & $\begin{array}{c}\text { Net Public } \\
\text { Radiation } \\
\text { Fatalities }\end{array}$ & $\begin{array}{c}\text { Worker } \\
\text { Construction } \\
\text { Fatalities }\end{array}$ & $\begin{array}{c}\text { Transport } \\
\text { Fatalities }\end{array}$ & $\begin{array}{c}\text { Net } \\
\text { Hypothetical } \\
\text { Fatalities }\end{array}$ \\
\hline \hline 1 & 0.0876 & -0.00093 & 0.0040 & 0.0600 & 0.1506 \\
\hline 15 & 0.0856 & -0.00097 & 0.0010 & 0.0200 & 0.1056 \\
\hline 25 & 0.0856 & -0.00097 & 0.0010 & 0.0160 & 0.1016 \\
\hline 75 & 0.0836 & -0.00096 & 0.0005 & 0.0080 & 0.0912 \\
\hline 100 & 0.0832 & -0.00093 & 0.0004 & 0.0070 & 0.0897 \\
\hline
\end{tabular}

Results of Risk Optimization Analysis

A risk optimization analysis was performed to determine the cost savings from the remedial action, the life cycle costs for the remedial action, the value of the net dose avoided, and the value of other avoided risks and damages. The purpose of this was to select the optimum radionuclide concentration for the risk-based remediation goal. The risk-based remediation goals used to assess these costs and benefits were $1,15,25,75$, and the 100 $\mathrm{mrem} / \mathrm{yr}$ limit. The optimization (ALARA) analysis produced the following results for each: cost savings from the remediation; cost to remediate, package, ship, and dispose of the contaminated soil; value of the radiation dose averted to the workers, visitors, and public; value of other risks and damages avoided by remediation; net benefit analysis; and qualitative factor analysis. The results for the net-benefit analysis using the $15 \mathrm{mrem} / \mathrm{yr}$ remediation goal were as follows:

1) Cost of excavation and disposal

2) Benefits from reduced well sampling and potential real-estate sale

3) Value of collective dose averted or expended (negative)

4) Value of avoided risks and damages

Net Benefit or Cost (negative)
$\$-28,650,610$

$\$ \quad 819,000$

$\$ \quad-424,000$

$\$ \quad 27.640$

$\$-28,227,970$

Table E-3 lists the net benefits for the various remediation goals/limits. Based on risk avoidance and economic factors alone, it was concluded that none of these goals were reasonably achievable since no net benefit would be achieved below $100 \mathrm{mrem} / \mathrm{yr}$. 
Table E-3 Net Benefit at Various Remediation Goals/Limit

\begin{tabular}{|c|c|}
\hline $\begin{array}{c}\text { Risk-based Remediation } \\
\text { Goals/Limit } \\
\text { (mrem/yr) }\end{array}$ & $\begin{array}{c}\text { Net Benefit/Cost } \\
\text { (1997 Dollars) }\end{array}$ \\
\hline 1 & $\$-64,486,330$ \\
\hline 15 & $\$-28,227,970$ \\
\hline 25 & $\$-24,386,860$ \\
\hline 75 & $\$-16,618,970$ \\
\hline 100 & $\$-15,930,460$ \\
\hline
\end{tabular}

However, compliance with the applicable Federal regulations and guidelines must be achieved. The DOE's public radiation dose limit in DOE Order 5400.5 which is the same as that in the proposed 10 CFR 834 and the NRC's relevant and appropriate requirement of 100 mrem/yr must be met. Also since the EPA's regulatory risk range in the Comprehensive Environmental Response, Compensation, and Liability Act (CERCLA or Superfund Act) of 0.0001 to 0.000001 was exceeded at the HWMF remediation must be performed. Therefore, whatever costs are needed to comply with these Federal rules must be expended. The decision-makers must decide what level below these regulatory levels is reasonable based on the net benefit and the other societal, technical, and political factors. The other societal and political factors to be considered for the selection of the optimal level for BNL's HWMF remediation are summarized below.

- Relocation of the habitat for an endangered species

- Workers' and community concerns

- Political factors

- Regulatory fines, enforcement actions and administrative orders

- Potential liabilities from civil suits

The ALARA level selected for this analysis was the level at which the costs to remediate and the net fatalities begin to increase dramatically. This occurred at the $15 \mathrm{mrem} / \mathrm{yr}$ level for the soil concentration distribution at BNL's Hazardous Waste Management Facility; it corresponded to $230 \mathrm{pCi} / \mathrm{g}$ for cesium-137 assuming an open-space land use and the agreedupon 50 years of Federal control at BNL. The preliminary remediation guideline that was proposed by DOE to the State and Federal regulators was $67 \mathrm{pCi} / \mathrm{g}$ (cesium-137). This guideline was based on a commercial industrial land use and 50 years of control. Therefore, the $67 \mathrm{pCi} / \mathrm{g}$ preliminary remediation guideline for the HWMF was more protective for the hypothetical future user than the level derived in this report using risk-based decision techniques. 
The corresponding derived concentration guideline for strontium- 90 was $5,800 \mathrm{pCi} / \mathrm{g}$ using risk-based decision techniques. An alternate analysis was performed to derive a soil to water cleanup guideline for strontium 90 that would assure protection of groundwater. This was needed since strontium 90 leaches more quickly through the soil than cesium-137 and thus must also be controlled to protect the sole-source aquifer. However, the value of the alternate derived concentration guideline to demonstrate compliance with the maximum concentration level in the EPA's Primary Drinking-Water Regulation was $45 \mathrm{pCi} / \mathrm{g}$ for strontium-90. As was the case with cesium-137, the preliminary remediation guideline that was proposed by DOE to the State and Federal regulators for strontium-90 was lower, in this case $15 \mathrm{pCi} / \mathrm{g}$. Therefore, the $15 \mathrm{pCi} / \mathrm{g}$ preliminary remediation guideline for the HWMF was more protective for the hypothetical future user than the level derived in this report using risk-based decision techniques.

The projected costs for excavation and offsite disposal as estimated in the draft Feasibility Study (CDM 1996b) was $\$ 38$ million. By contrast, the estimated cost to cleanup to the level derived in this report using risk-based decision techniques was about $\$ 28$ million. These lower remediation guidelines will result in an additional $\$ 10$ million being expended to remediate to the level that is expected to be selected by the State and Federal regulators. The benefits from these lower guidelines include reduction in risk to future visitors, in risk to potential residents if active controls fail, in residual radioactive material in soil, and in radioactive leachate that could contaminate the sole-source aquifer.

\section{Figure E-1 Optimization of Protection Costs and Hypothetical Fatalities at BNL's Hazardous Waste Management Facility}

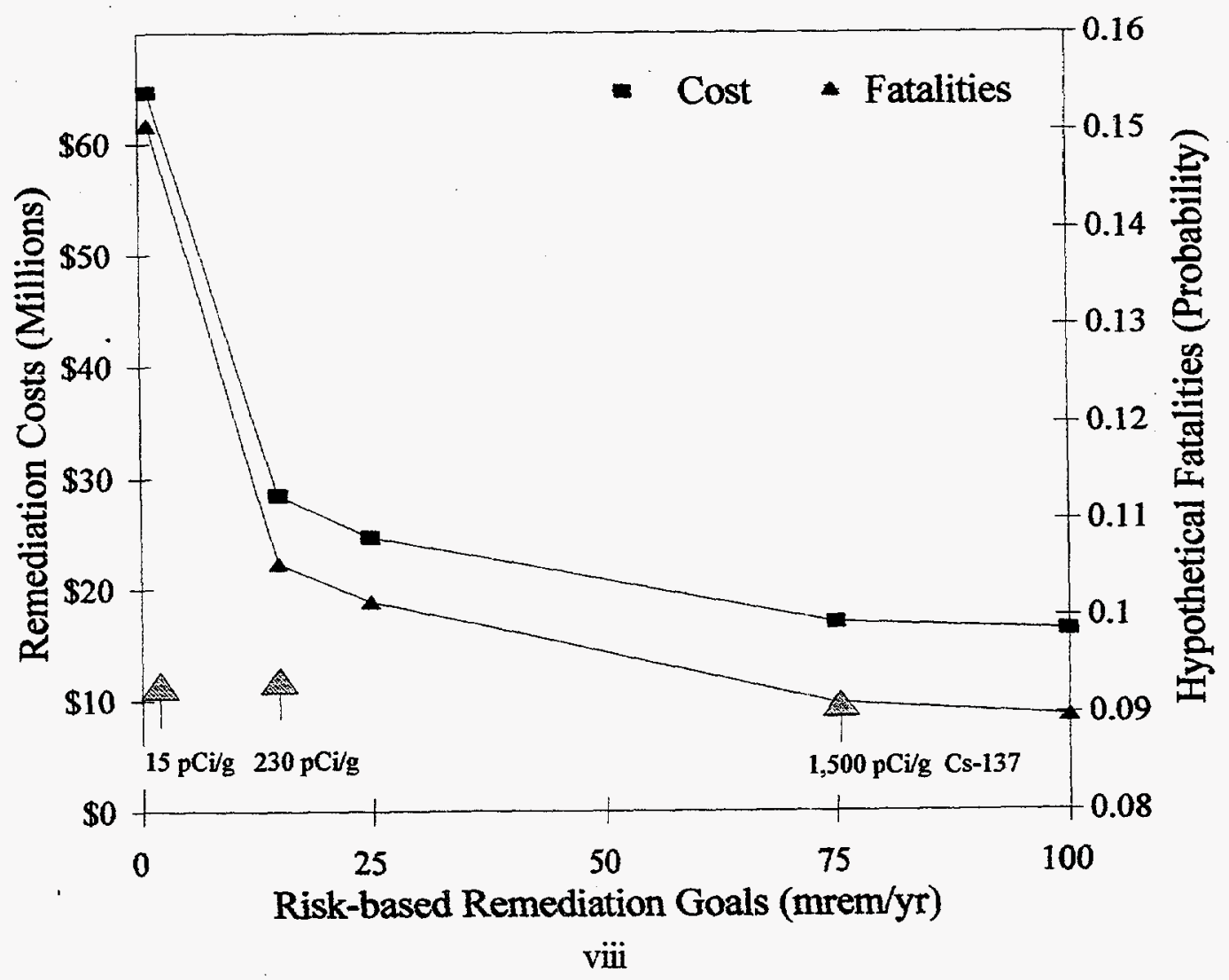




\section{Ackmowledgments}

This report was prepared for the Brookhaven National Laboratory's (BNL) Office of Environmental Restoration (OER) and the Department of Energy's (DOE) Office of Environment, Safety, and Health. The authors wish to thank William Gunther and James Brower from BNL's OER and Andy Wallo III, Harold Peterson Jr., J. Bachmaier, G. Roles, and Kenneth Duvall from DOE's Office of Environmental Policy and Assistance (EH-412) for their support and encouragement in this effort.

Special thanks go to John Mauro from S. C. Cohen \& Associates for his technical review of some of the models/calculations and the overall organization and format of the report. His comments and advice on the dose assessments have greatly improved the quality of the report. The authors also wish to thank Avril Woodhead from BNL's Information Services Division for her excellent editing. Finally, we thank Maria Beckman and Grace Webster from BNL's Department of Advanced Technology and Arlean Vanslyke from BNL's Department of Applied Science for document preparation. 


\section{TABLE OF CONTENTS}

Page

ABSTRACT $\ldots \ldots \ldots \ldots \ldots \ldots \ldots \ldots \ldots \ldots \ldots \ldots \ldots \ldots \ldots \ldots \ldots \ldots \ldots \ldots \ldots$

EXECUTIVE SUMMARY $\ldots \ldots \ldots \ldots \ldots \ldots \ldots \ldots \ldots \ldots \ldots \ldots \ldots \ldots \ldots \ldots$ iii

$1.0 \quad$ INTRODUCTION $\ldots \ldots \ldots \ldots \ldots \ldots \ldots \ldots \ldots \ldots \ldots \ldots \ldots \ldots \ldots \ldots \ldots \ldots$

2.0 RADIOLOGICAL RISK ASSESSMENTS ASSOCIATED WITH LARGE-SCALE EXCAVATION AND OFF-SITE DISPOSAL OF CONT AMINATED SOIL $\ldots \ldots 7$

2.1 Dose Averted or Expended to Present Workers $\ldots \ldots \ldots \ldots \ldots \ldots \ldots$

2.1.1 Dose to Present Workers from Initial Radiological Conditions . . . 10

2.1.1.1 Radiation Exposure Scenario . . . . . . . . . . . . . . . 10

2.1.1.2 Assumptions ............................... 11

2.1.1.3 Calculations and Results ...................... 11

2.1.2 Dose to Present Workers after Remediation .............. 12

2.1.2.1 Radiation Exposure Scenario . . . . . . . . . . . . . . . . 12

2.1.2.2 Assumptions $\ldots \ldots \ldots \ldots \ldots \ldots \ldots \ldots \ldots \ldots \ldots \ldots \ldots, 12$

2.1.2.3 Calculations and Results . ................... 13

2.1.3 Dose to Workers Excavating, Packaging, and Storing the Soil

On-Site ............................. 14

2.1.3.1 Radiation Exposure Scenario $\ldots \ldots \ldots \ldots \ldots \ldots \ldots \ldots \ldots \ldots \ldots \ldots$

2.1.3.2 Assumptions ................................ 15

2.1.3.3 Calculations and Results .................... 16

2.1.4 Dose to Drivers/Workers from Transporting and Disposing of the Soil Off-site .......................... 19

2.1.4.1 Radiation Exposure Scenario ..................... 19

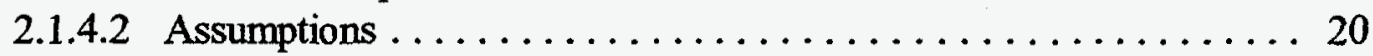

2.1.4.3 Calculations and Results .................... 22

2.1.5 Dose Averted or Expended to Present Workers: Summary ....... 24

2.2 Dose Averted or Expended to Future Members of the Public $\ldots \ldots \ldots \ldots .25$

2.2.1 Dose to Future Visitors to this Open Space from Existing

Radiological Conditions ....................... 25

2.2.1.1 Radiation Exposure Scenario . . . . . . . . . . . . . . . . 25

2.2.1.2 Assumptions $\ldots \ldots \ldots \ldots \ldots \ldots \ldots \ldots \ldots \ldots \ldots, 26$

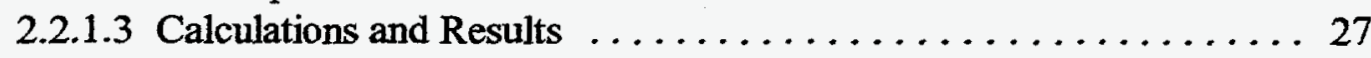


2.2.2 Dose to Future Visitors to this Open Space after

Remediation .......................... 28

2.2.2.1 Radiation Exposure Scenario . . . . . . . . . . . . . . . 28

2.2.2.2 Assumptions . ........................... 28

2.2.2.3 Calculations and Results ................... 28

2.2.3 Dose to the Public from Excavating, Packaging, and Storing the Soil On-

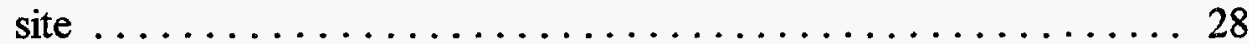

2.2.3.1 Radiation Exposure Scenario $\ldots \ldots \ldots \ldots \ldots \ldots \ldots \ldots$

2.2.3.2 Assumptions ......................... 29

2.2.3.3 Calculations and Results ................. 30

2.2.4 Dose to the Public from Transporting and Disposing of Soil Off-site . 33

2.2.4.1 Radiation Exposure Scenario ................. 33

2.2.4.2 Assumptions ........................ 33

2.2.4.3 Calculations and Results ................. 35

2.2.5 Dose Averted or Expended to Members of the Public: Summary ... 36

2.3 Dose to Basement Resident: Failure of Active Controls ........... 37

2.3.1 Radiation Exposure Scenario $\ldots \ldots \ldots \ldots \ldots \ldots \ldots \ldots \ldots \ldots \ldots \ldots$

2.3.2 Assumptions .............................. 38

2.3.3 Calculations and Results ..................... 41

2.4 Dose to a Resident from Drinking Groundwater .............. 44

2.4.1 Radiation Exposure Scenario: Soil-to-Water Screening Levels and Remediation Guidelines .................... 44

2.4.2 Assumptions: Soil-to-Water Screening Levels and Remediation Guidelines ............................. 45

2.4.3 Calculations and Results: Soil-to-Water Screening Levels and Comparison to Measured Soil and Groundwater Concentrations ........................ 46

2.4.4 Calculation and Results: Soil-to-Water Remediation Guidelines . . . . . 54

3.0 RISK OPTIMIZATION (ALARA) ANALYSIS ASSOCIATED WITH LARGE-SCALE EXCAVATION AND OFF-SITE DISPOSAL OF CONTAMINATED SOIL $\ldots \ldots \ldots \ldots \ldots \ldots \ldots \ldots \ldots \ldots \ldots \ldots \ldots \ldots \ldots$

3.1 Description of Radiological Conditions and the Remedial Alternative ..... 62

3.2 Cost Savings from the Remediation $\ldots \ldots \ldots \ldots \ldots \ldots \ldots \ldots \ldots, 63$

3.3 Cost to Excavate, Package, Ship, and Dispose of the Contaminated Soil ...63

3.4 Radiation Dose Averted to Workers, Visitors, and Public .......... 65 
3.5 Value of Other Risks and Damages Avoided by Remediation . . . . . . 67

3.6 Net-Benefit Analysis . . . . . . . . . . . . . . . . . 68

3.7 Qualitative Factor Analysis . . . . . . . . . . . . . . 69

4.0 SUMMARY AND CONCLUSIONS $\ldots \ldots \ldots \ldots \ldots \ldots \ldots \ldots \ldots$

4.1 Results of Risk Assessments . . . . . . . . . . . . . . . 74

4.2 Results of Risk Optimization Analysis $\ldots \ldots \ldots \ldots \ldots \ldots \ldots 77$

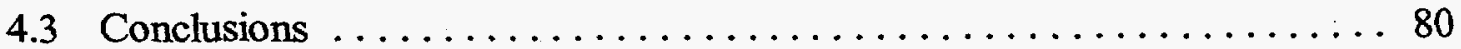

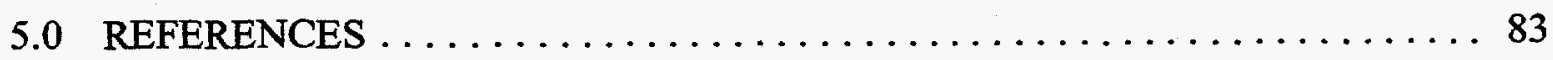

Appendix A RESRAD Pathways/Parameters for Hazardous Waste Management Facility (HWMF): Soil Remediation Guidelines, Soil-to-Water Screening Levels, and Dose to Visitors at the Open Space . . . . . . A-1

Appendix B Hazardous Waste Management Facility (HWMF): Soil Remediation Guidelines for Open-Space Scenario at 50 Years and $15 \mathrm{mrem} / \mathrm{yr}$ : RESRAD Printouts

Appendix C Hazardous Waste Management Facility (HWMF): Soil Volumes and Radionuclide Concentrations

Appendix D Dose to Workers from Environmental Remediation $\ldots \ldots \ldots \ldots$ D-1

Appendix E Dose to Workers from Transport and Disposal of Contaminated Soil: Microshield Printouts and Spreadsheets . . . . . . . . . E E-1

Appendix F Dose to the Future Visitors to the Open Space Before and After Environmental Remediation: RESRAD Printouts and Spreadsheets .........F-1

Appendix G Dose to the Public from Environmental Remediation: CAP88 Printouts and Spreadsheets . . . . . . . . . . . . . .

Appendix H Dose to Public from Transport and Disposal of Contaminated Soil: Microshield Printouts and Spreadsheets

Appendix I Dose to Basement Resident for the Failure of Active Controls Scenario: RESRAD Printouts and Spreadsheets I-1 
Appendix J Hazardous Waste Management Facility (HWMF): RADS

Net-Benefit Analysis Worksheets and Excavation/Disposal Cost

Spreadsheets

$\mathrm{J}-1$ 


\section{LIST OF FIGURES}

Figure 1.0-1 Operable Unit I Potential Sources of Contamination $\ldots \ldots \ldots \ldots 1$

Figure 1.0-2 Current Land Use at Brookhaven National Laboratory $\ldots \ldots \ldots \ldots 3$

Figure 1.0-3 Planned Future Land Use (post-closure) at Brookhaven National Laboratory $\ldots \ldots \ldots \ldots \ldots \ldots \ldots \ldots \ldots \ldots \ldots \ldots \ldots$

Figure 2.1-1 Irradiation Geometries with an Anthropomorphic Phantom Used in Calculating the Dose Equivalent from External Radiation (ICRP 1987) . .23

Figure 2.3-1 Failure of Active Controls Scenario: Resident in Basement. . . . . . . . 39

Figure 2.4-1 Dose (mrem/yr) and Concentration (pCi/l) vs. Time Associated with $1 \mathrm{pCi} / \mathrm{g}$ of Sr-90, U-234, U-235, and U-238 ............ 48

Figure 2.4-2 Hazardous Waste Management Facility: Monitoring Well 88-04 Sr-90 Concentrations ...................... 49

Figure 2.4-3 Simulated 1995 Position of Sr-90 Continuous Source Plume . . . . 50

Figure $2.4-4$ Simulated Initial Distribution of $\mathrm{Sr}-90 \ldots \ldots \ldots \ldots \ldots \ldots \ldots$

Figure 2.4-5 Simulated Distribution of Sr-90 after 14 Years of Pumping at OU I

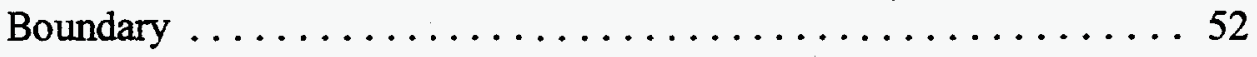

Figure 2.4-6 Simulated Distribution of Sr-90 in Year $2065 \ldots \ldots \ldots \ldots \ldots$

Figure 3.3-1 Optimization of Protection Costs and Hypothetical Fatalities at BNL's Hazardous Waste Management Facility ................ 64

Figure 4.3-1 Optimization of Protection Costs and Hypothetical Fatalities at BNL's Hazardous Waste Management Facility ............... 81

\section{LIST OF TABLES}

Table 2.1-1 Derived Concentration Guideline Limits (DCGL) for Undeveloped OpenSpace Equivalent to $15 \mathrm{mrem} / \mathrm{yr}$ after 50 Years of Federal Control ....9

Table 2.1-2 Collective Dose to Present Workers after Remediation ......... 14

Table 2.1-3 Collective Dose to Environmental Remediation Workers $\ldots \ldots \ldots 19$ 
Table 2.1-4 Volumes of Soil that Require Off-Site Disposal and Number of Trips to the Fluor Daniels and Envirocare Waste Disposal Sites . . . . . . 21

Table 2.1-5 Collective Dose to Drivers/Workers from Transport and Off-Site Disposal ........................... 24

Table 2.1-6 Collective Dose Averted or Expended to Present Workers: Summary . 25

Table 2.2-1 Collective Dose to the Future Visitors after Remediation . . . . . . . 29

Table 2.2-2 Fugitive Dust Release Rates: Cesium-137 and Strontium-90 . . . . . 31

Table 2.2-3 Collective Dose (first year only) to the Public from Remediation ... . 32

Table 2.2-4 Collective Dose to the Public Resulting from Transport and Off-site Disposal . ...................... 36

Table 2.2-5 Collective Dose Averted or Expended to Future Members of the Public: Summary ........................ 37

Table 2.3-1 Dose-to-Soil Concentration Ratios for Top 6 Inches of Contaminated Soil at 50 Years - Excluding Direct Radiation . . . . . . . . . 42

Table 2.3-2 Dose-to-Soil Concentration Ratio for Contaminated Soil Buried Under 3 Feet of Clean Fill at 50 Years - Excluding Direct Radiation . . 42

Table 2.3-3 Dose-to-Soil Concentration Ratio for Soil Surrounding Basement - Direct Radiation .......................44

Table 2.3-4 Dose-to-Soil Concentration Ratio for the Failure of Active Controls Scenario

Table 2.3-5 Concentration of Buried Soil (Average HWMF Mixture) Equivalent to

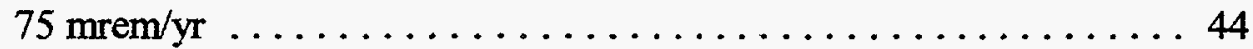

Table 2.4-1 Peak Concentrations in Water Beneath Remediation Site per Unit Activity Concentration in Soil (Time of Maximum Groundwater Concentration in Years); Water Ingestion Dose-Conversion Factors; USEPA's MCLs; and Soil-to-Groundwater Screening Levels . . . . . . 56

Table 2.4-2 Worst-case Concentrations of Sr-90, Ra-226, U-234, U-235 and U-238 per Unit Soil Activity Concentration over 1,000 Years . . . . . 59

Table 3.3-1 Cost to Remediate at Various Remediation Goals/Limit . . . . . . 64 
Table 3.4-1 Net Radiation Dose Averted or Expended at Various Remediation Goals/Limit $\ldots \ldots \ldots \ldots \ldots \ldots \ldots \ldots \ldots \ldots \ldots \ldots 6 . \ldots \ldots$

Table 3.4-2 Value of Radiation Dose Averted or Expended at Various Remediation Goals/Limit ........................... 67

Table 3.5-1 Value of Other Risks and Damages Averted or Caused at Various Remediation Goals/Limit 68

Table 3.6-1 Net Benefit or Costs at Various Remediation Goals/Limit . . . . . . . 69

Table 4.1-1 Derived Concentration Guideline Limits (DCGL) for Undeveloped Open-Space Equivalent to $15 \mathrm{mrem} / \mathrm{yr}$ after 50 Years of Federal Control ............................. 74

Table 4.1-2 Estimated Hypothetical Fatalities Associated with Remediation . . . . 76

Table 4.2-1 Net Benefit or Cost at Various Remediation Goals/Limit $\ldots \ldots \ldots 78$ 


\subsection{INTRODUCTION}

The Hazardous Waste Management Facility (HWMF) is one of the areas undergoing environmental remediation at Brookhaven National Laboratory (BNL). The BNL site was added to the National Priority List by the U.S. Environmental Protection Agency (EPA) on December 21, 1989. An interagency agreement, signed shortly thereafter, established the framework for the environmental restoration activities across the site. The U.S. Department of Energy (DOE) is required to comply with the terms and conditions of the associated Federal Facilities Agreement (Administrative Docket Number II-CERCLA - FFA-00201) which became effective in May 1992.

This risk assessments and optimization (ALARA) analysis for the remediation of BNL's HWMF were performed to provide an example case for the Department of Energy's Office of Environment, Health and Safety (EH-412). It was designed to fulfill the applicable or relevant and appropriate requirements in Title 40 of the Code of Federal Regulations (CFR) Part 300.430 (e) for evaluating remedial alternatives, as well as the ALARA requirements in DOE 5400.5 (USDOE 1991b) and proposed 10 CFR Part 834, Subpart G (USDOE 1993), for release of bulk material that contains residual radioactive material. The new requirements in the U.S. Nuclear Regulatory Commission's Decontamination \& Decommissioning rule 10 CFR Part 20, Subpart E (USNRC 1997) were also considered in the assessment. Also considered, to the extent possible, were the draft requirements for radiation site cleanups at federal facilities that were circulated for review by EPA in 1995.

The HWMF is a fenced, 12-acre (4.8 ha) lot, located in a wooded area in the southeastern quadrant of the site (see Figure 1.0-1). This restricted-access area was originally used as a munitions storage area and livery stable by the Army (Camp Upton) during and after World War I. Since 1947, this site has been used by Associated Universities Inc. as the central receiving facility for processing, limited treatment, and storage of hazardous and radioactive waste.

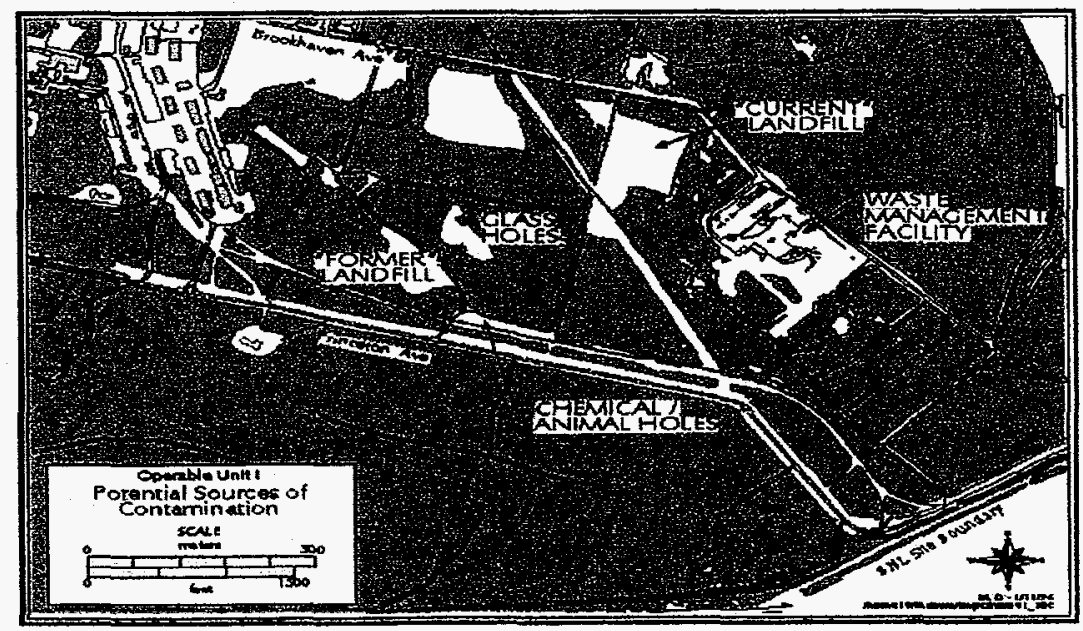

Figure 1.0 - 1 Operable Unit I Potential Sources of Concern 
Approximately one fourth of the 12-acre lot is paved or covered with temporary storage buildings. Approximately 5 acres, of the surface is contaminated with mixed fission-products and activation products from previous site operations. About 8,000 to 78,000 cubic yards of soil predominately contaminated with cesium- 137 and strontium- 90 will require treatment or excavation/disposal. Other radionuclides that are present include tritium, americium-241, plutonium-238/-239/-241, uranium-235/-238, cobalt-60, and curium-242. None of these other isotopes were detected at concentrations that exceeded the derived concentration guideline levels (DCGL) for an undeveloped recreational area (undeveloped open-space scenario) during the remedial-investigation sampling program.

This parcel of property is currently designated for commercial/industrial use. A BNL report, entitled "BNL Future Use Plan," was recently published to document the stakeholders' "consensus" on the post-closure use of the BNL site. Several public meetings were held to discuss various land-use options. It was agreed that when operations cease at BNL, the HWMF would be converted from commercial/industrial use to open space. Figure 1.0-2 shows current land use, and Figure 1.0-3 shows the future land use that was agreed upon by the BNL stakeholders in 1995 (BNL 1995).

This report presents dose assessments and a cost analysis that parallel those presented in the Feasibility Study for Operable Unit I done by CDM Federal Programs Corporation (CDM 1996b). However, the assessment in this report uses an open-space scenario. The open-space scenario would allow a higher concentration of radioactive contamination to remain onsite. Radiological dose assessments are described that calculated the risk averted to workers and the public associated with the remedial alternative 4: Large-Scale Excavation and Off-site Disposal presented in the Feasibility Study for Operable Unit I.

Next, a special dose assessment was performed to assess potential doses associated with the failure of active controls that are being considered for this remedial alternative, namely a town zoning restriction as open-space. This scenario assumed that following the transfer of the BNL property to New York State (NYS), a dwelling was constructed at the HWMF despite Brookhaven Town's zoning restrictions. The scenario further assumed that one of the residents occupies a bedroom in the basement. Thus, the active control measures were assumed to have failed and a value for the upper dose cap of $75 \mathrm{mrem} / \mathrm{yr}$ was used to derive alternate soilconcentration guidelines. This value was based on the DOE radiation exposure limit for the public of $100 \mathrm{mrem} / \mathrm{yr}$. A safety margin below this limit was used to allow for radiation exposure from a future nuclear facility. The single-source dose constraint level of $25 \mathrm{mrem} / \mathrm{yr}$ (NCRP 1987 ) is the currently accepted value and was used as the safety margin. This dose assessment derives alternate soil-concentration guidelines that would ensure that if zoning regulations failed and a person used the property for a residence, they would not receive a radiation dose above the public dose limit.

A second special dose assessment was performed because the BNL property is located on an aquifer that was designated by the EPA as a "sole-source aquifer." This assessment determined if the EPA's National Primary Drinking Water Regulation (NPDWR) would be met. EPA's MCLs apply to drinking water at the tap from major water supply systems. However, in 
Figure 1.0-2 Current Land Use at Brookhaven National Laboratory

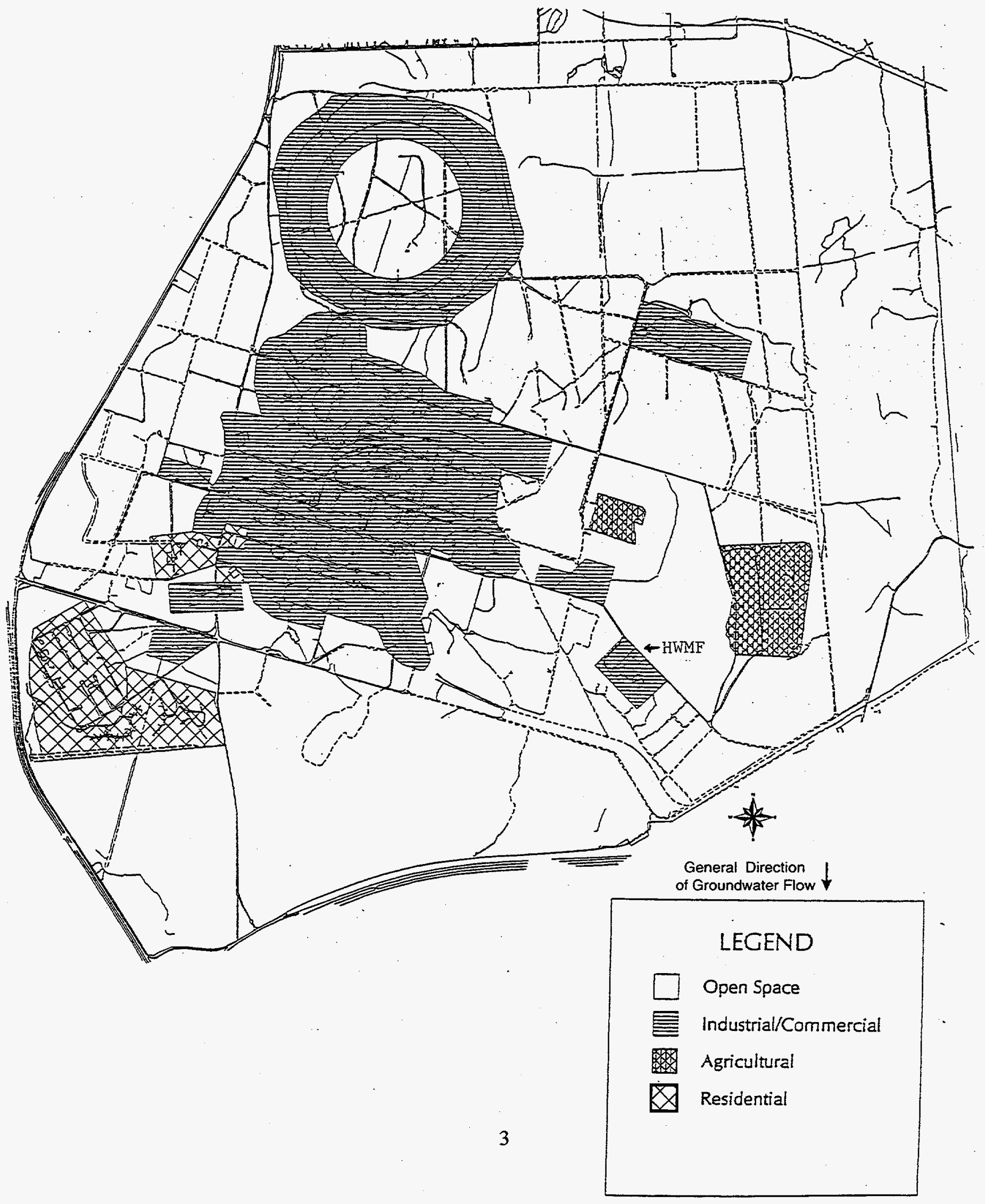


Figure 1.0-3 Planned Future Land Use (post-closure) at Brookhaven National Laboratory

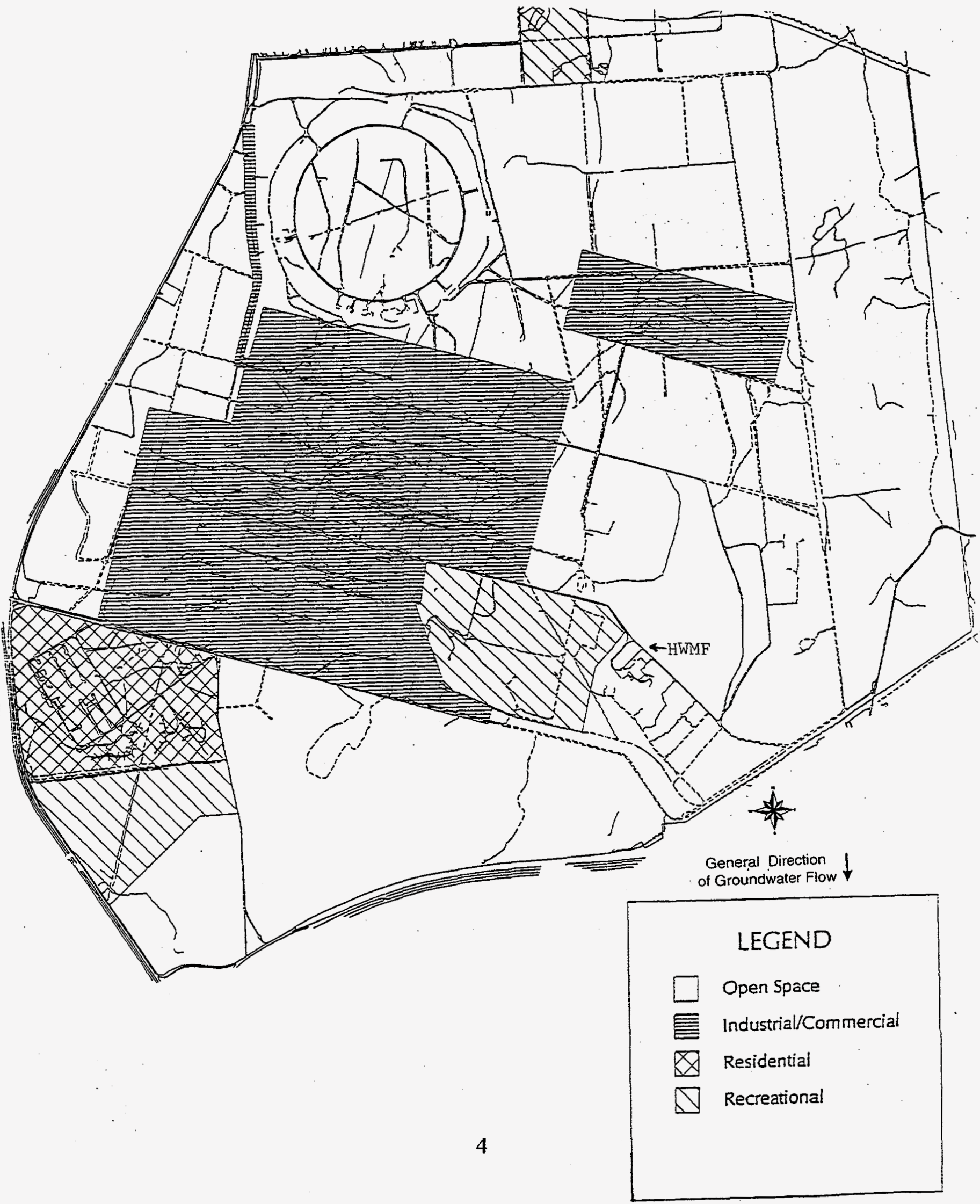


this assessment, calculations were performed to see if these MCLs would be exceeded in the groundwater. Because of water infiltration from precipitation and runoff into the contaminated soil, the local resident's primary drinking water supply, namely a private well, could become contaminated. It should be noted that the concentrations in soil that were calculated to protect the ground water, protects it to a $4 \mathrm{mrem}$ in a year dose constraint assuming just the water ingestion pathway rather than the $15 \mathrm{mrem}$ in a year dose constraint for all pathways. This derived concentration guideline may be more restrictive than the soil-concentration derived to meet the 15 $\mathrm{mrem} / \mathrm{yr}$ soil remediation limit for nuclides, such as uranium-235 and strontium-90. Therefore, this dose assessment will derive alternate soil-concentration guidelines that would ensure that residents drinking the groundwater from this sole-source aquifer would not receive a radiation dose above the EPA's safe drinking water standard of $4 \mathrm{mrem} / \mathrm{yr}$.

The radiation-exposure scenarios, assumptions, calculations and results for the various radiological risk assessments are discussed in the following sections:

\subsection{Dose Averted to Present Workers \\ 2.2 Dose Averted to Future Members of the Public \\ 2.3 Dose to a Basement Resident Assuming the Failure of Active Controls \\ 2.4 Dose to a Resident from Drinking Groundwater}

To make an informed decision about the remediating of a site contaminated with radioactive materials, it is essential that the decision-makers are provided with facts about the costs, benefits, risks, and other societal and political considerations. Therefore, a decision-management tool was employed to evaluate the net benefit quantitatively and qualitatively. This decisionmaking tool, developed at Brookhaven National Laboratory's ALARA Center is a software application called Radiological Assessment \& Design System (RADS), or simply RADS Version 2.0 (Dionne 1994). One module in this software package determines if a protective measure that reduces radiation exposure is reasonably achievable or ALARA. It was used to calculate the net benefit of the large-scale excavation and off-site disposal which is the remedial alternative preferred by the EPA: Region II, NYS, and the public. In addition, the qualitative factor analysis, from the RADS software application, provides the decision-makers with other societal and political factors needed to make an informed decision.

The optimization (ALARA) analysis input data, information, and results for the various modules of the net benefit and qualitative factor analysis are given in the following sections:

3.1 Description of Radiological Conditions and Selected Remedial Alternative

3.2 Cost Savings from the Remediation

3.3 Cost to Remediate, Package, Ship, and Dispose of the Contaminated Soil

3.4 Radiation Dose Averted to the Workers, Visitors, and Members of the Public

3.5 Value of Other Risks and Damages Avoided by Remediation 


\subsection{Net Benefit Analysis}

\subsection{Qualitative Factor Analysis}

The results from the risk assessments and the optimization (ALARA) analysis can be used by decision-makers to select the optimum risk-based remediation level. They can also be used to make an informed risk management decision as to the most appropriate remedial alternative. To evaluate the various remedial alternatives, a similar analysis would be performed for the other remedial alternatives. Then, based on the net benefits and the qualitative factors the decisionmakers could select the optimum alternative. These methods also may be of value for risk assessors and decision-makers at the 5,000 estimated sites in the United States that are contaminated with radioactive materials. Some 250 of them belong to Federal agencies, primarily DOE and the Department of Defense (DOD) (Wolbarst 1996). 


\subsection{RADIOLOGICAL RISK ASSESSMENTS ASSOCIATED WITH LARGE-SCALE EXCAVATION AND OFF-SITE DISPOSAL OF CONTAMINATED SOIL}

The potential radiological impacts resulting from remediation include the radiation dose to workers and the nearby public during excavation, followed by the dose to the workers and public from the transport to, and storage of, the contaminated soil at a low-level waste treatment/storage/disposal facility (TSD). These remedial impacts could offset some of the long-term radiological risk to be averted and other benefits to be achieved from the remediation. The analysis of other impacts from remediation, such as damage to the habitat of an endangered species, accidents from construction activities, and deaths from transportation accidents are not described in this radiological risk assessment. However, they were quantified or qualitatively assessed, as discussed in chapter 3.0, and were considered in the risk optimization (ALARA) analysis.

For more than 20 years, the HWMF has been the RCRA facility for processing, limited treatment, and storage of radioactive and hazardous waste operations at BNL. Operations at this facility are being terminated and the site is scheduled to be remediated in 1999. This chapter estimates the collective dose averted to workers and the public from remediating the contaminated soil, the design and construction of which is being planned. To calculate the net dose to be avoided by remediating the contaminated soil, these estimates took into account the collective dose expended to excavate the 8,000 to $78,000 \mathrm{yd}^{3}\left(6,000\right.$ to $\left.60,000 \mathrm{~m}^{3}\right)$ of contaminated soil at the HWMF, package it into B-25 containers, transfer the containers to the new HWMF facility, and transport and dispose of them at the Envirocare Disposal Site in Clive, Utah, and at Fluor Daniels Solid Waste Disposal Site in Richland, Washington. The relationship between soil cesium-137 concentration and volume are described in Appendix $\mathrm{C}$ and are critical to defining the radioactive source-term for the various dose assessments. The cesium-137 concentration intervals that are listed in the table in Appendix C entitled Soil Volumes/Areas vs. Depth and Concentration for HWMF, were as follows:

- $67 \mathrm{pCi} / \mathrm{g}$ - Risk-based derived concentration guideline level associated with a future use as commercial/industrial, a 50-year Federal control period, and a remedial goal of $15 \mathrm{mrem} / \mathrm{yr}$ (CDM 1996b).

- $600 \mathrm{pCi} / \mathrm{g}$ - Approximate cesium-137 waste concentration limit, i.e., waste acceptance criteria from Envirocare's Byproduct Material Licensee (Utah License No. 2300249, Amendment 20 - Utah 1995) with a small margin of safety (actual limit of $560 \mathrm{pCi} / \mathrm{g}$ was rounded to the nearest $100 \mathrm{pCi} / \mathrm{g}$ ).

- $2,800 \mathrm{pCi} / \mathrm{g}$ - Lower limit for cesium-137 for Type A material from Westinghouse Hanford's Waste Acceptance Criteria (WHC 1995). 
- 5,600 pCi/g - CDM Federal Program's estimate of the highest level of cesium-137 that when combined with other lower-level contaminated soil, i.e., less than $300 \mathrm{pCi} / \mathrm{g}$, would still meet Hanford's lower limit for non-stabilized waste, listed above (CDM 1996b).

- 30,000 $\mathrm{pCi} / \mathrm{g}$ - CDM Federal Program's estimate of the highest level of cesium-137 that, when combined with other lower-level contaminated soil, i.e., less than 300 $\mathrm{pCi} / \mathrm{g}$, would still meet Envirocare's average concentration limit for cesium-137, listed above (CDM 1996b).

Each of the following dose assessments describes the radiation exposure scenario, the assumptions made, presents the calculations, and summarizes the calculated results. Risk-based remediation goals/limits of $1,15,25,75$, and the $100 \mathrm{mrem} / \mathrm{yr}$ were used to assess the doses to the workers and public. The bases for the selecting these values were as follows:

- $1 \mathrm{mrem} / \mathrm{yr}$-National Council on Radiation Protection and Measurements Report 91 Recommendations on Limits for Exposure to Ionizing Radiation (NCRP 1987) definition for annual negligible individual risk level.

- $15 \mathrm{mrem} / \mathrm{yr}$ - EPA's Draft Radiation Site Cleanup Standard 40 CFR 196 (USEPA 1995) proposed cleanup limit for radiation-sites that was forwarded to the Office of Management and Budgets for consideration in late 1996, but was withdrawn on December 19, 1996.

- $25 \mathrm{mrem} / \mathrm{yr}$ - NRC's revision to Occupational Radiation Protection 10 CFR 20 (USNRC 1997): radiological criteria for unrestricted use during license termination; EPA's Environmental Radiation Protection Standards for Nuclear Power Operation 40 CFR 190 (USEPA 1977): radiation dose criteria for the nuclear fuel cycle; Licensing Requirements for Land Disposal of Radioactive Waste 10 CFR 61(USNRC 1982): siting criteria for a radioactive waste disposal facility; NCRP Report 91 Recommendations on Limits for Exposure to Ionizing Radiation, (NCRP 1987): single-source dose constraint; and DOE's Radiation Protection of the Public and the Environment, DOE Order 5400.5 (USDOE 1991b) and proposed 10 CFR Part 834 (USDOE 1993): dose constraint of $30 \mathrm{mrem} / \mathrm{yr}$ for a single source.

- $75 \mathrm{mrem} / \mathrm{yr}$ - DOE's (USDOE 1991b) and NRC's (USNRC 1990) radiation limit for the public of $100 \mathrm{mrem} / \mathrm{yr}$ with a $25 \mathrm{mrem} / \mathrm{yr}$ safety margin. This safety margin was based on the NCRP's prospective single-source dose constraint (NCRP 1987). This upper-dose cap is the most restrictive of the NRC's or EPA's draft constraints for assessing failure of active controls. 
- $100 \mathrm{mrem} / \mathrm{yr}$ - DOE's Radiation Protection of the Public and the Environment DOE Order 5400.5 (USDOE 1991b), NRC Standards for Protection Against Radiation 10 CFR 20 (USNRC 1990), and EPA's proposed Federal Radiation Protection Guidance for Exposure of the General Public (USEPA 1993b) radiation limit for the public.

DCGLs were calculated for each of these risk-based remediation goals/limits using the RESRAD Version 5.61 software developed by Argonne National Laboratory (ANL 1993a). An open-space scenario was used in which thirty visitors were assumed to go for walks inside the former HWMF site after the 50-year control period agreed upon between DOE, EPA, and NYS has ended, i.e., 2047. The RESRAD parameters that were used for this undeveloped open-space scenario are given in columns 1 of Appendix A - RESRAD Pathways/Parameters for Hazardous Waste Management Facility: (HWMF) Derived Concentration Guideline Limit, Soil to Water Screening Levels, and Dose to Open Space Visitors. The table in Appendix C, Hazardous Waste Management Facility (HWMF): Soil Volumes and Areas and Depth Interval, lists the DCGLs for cesium-137 and strontium-90. These values are also shown in Table 2.1-1.

Table 2.1-1. Derived Concentration Guideline Limits (DCGL) for the Undeveloped Open-Space Scenario after 50 Years of Federal Control

\begin{tabular}{|c|c|c|}
\hline $\begin{array}{c}\text { Risk-Based Remediation } \\
\text { Goals/Limit } \\
\text { (mrem/yr) }\end{array}$ & $\begin{array}{c}\text { DCGL } \\
\text { Cesium-137 } \\
\text { (pCi/g) }\end{array}$ & $\begin{array}{c}\text { DCGL } \\
\text { Strontium-90 } \\
\text { (pCi/g) }\end{array}$ \\
\hline \hline 1 & 15 & 390 \\
\hline 15 & 230 & 5,800 \\
\hline 25 & 380 & 10,000 \\
\hline 75 & 1,140 & 29,000 \\
\hline 100 & 1,500 & 39,000 \\
\hline
\end{tabular}

In addition, methodologies for two special dose assessments were developed by BNL risk assessors and radiological environmental engineers to determine if the radiological criteria in the EPA's draft rule for Radiation Site Cleanup and the NRC's D \& D regulation (USNRC 1997) would be met. The first methodology estimated the dose to a resident assuming the failure of active controls (Section 2.3). The DCGL that produced the $75 \mathrm{mrem} / \mathrm{yr}$ proposed criteria was more restrictive for strontium- $90(300 \mathrm{pCi} / \mathrm{g}$ vs. $5800 \mathrm{pCi} / \mathrm{g})$ than that calculated from the futureuse scenario based on the $15 \mathrm{mrem} / \mathrm{yr}$ EPA proposed guideline and the undeveloped open-space scenario. Therefore, for strontium-90 the DCGL that was based on the failure of active controls scenario should be considered in deciding the final remediation level. 
The second methodology measured the present concentrations in groundwater and estimated the projected ones (Section 2.4). Groundwater modeling was performed by CDM Federal Programs in New York, New York to simulate the future migration of the current concentrations of strontium-90 in groundwater. These concentrations were compared against EPA's Maximum Contaminant Level (MCL) values proposed in 1991 to determine if they were or will be exceeded. Soil-to-water remediation guidelines were determined by CDM Federal Programs. CDM (CDM 1996b) stated that "An alternate remediation goal of $45 \mathrm{pCi} / \mathrm{g}$ for strontium-90 was calculated using the TAGM methodology, but was based on the maximum groundwater concentration measured during the 1994 to 1995 OU I remedial investigation program." This residual radionuclide concentration is such that off-site concentrations would not be expected to exceed EPA's strontium-90 MCL of $8 \mathrm{pCi} /$ over the next 1,000 years. Therefore, for strontium-90, the derived concentration guideline level based on leaching of radionuclides from soil-to-groundwater should be considered in deciding the final remediation level.

\subsection{Dose Averted or Expended to Present Workers}

\subsubsection{Dose to Present Workers from Initial Radiological Conditions}

\subsubsection{Radiation Exposure Scenario}

The only workers who will be allowed to enter the HWMF following it's closure in 1997 are BNL's environmental monitoring team and security personnel. Unauthorized access to this area is controlled by the Safety \& Environmental Protection Division and Security via a locked eight-foot fence.

Two environmental monitoring technicians were assumed to collect quarterly samples from the three monitoring wells, MW 88-03, -04 and -24 , in this fenced area. On average, they spent one hour sampling each well. The measured exposure rates at MW 88-03, 04, and 24 are $0.4,0.3$, and $15.0 \mathrm{mR} / \mathrm{hr}$ at waist level, respectively. These exposure rates were measured on 11/13/95 using a Eberline PRM-7 Micro R/hr meter that was recently calibrated to cesium-137 (Dionne 1995).

A security guard was assumed to inspect the fenced-in area monthly for adequacy of the chain-link fence and breaches of security. On the average, one hour per month was spent on the inspection. The average exposure rate that was measured along the perimeter of the fence was $0.04 \mathrm{mR} / \mathrm{hr}$ at waist level. These exposure rates were measured on 01/31/97 using a Eberline PRM-7 Micro R/h meter that was recently calibrated to cesium-137 (Dionne 1997). 


\subsubsection{Assumptions}

The measured exposure rates decrease by radioactive decay over the 80 years of operational and post-closure sampling (cesium-137 half-life 30.17 years). The reduction from erosion and runoff are assumed to be negligible due to the dense vegetation and flat topography of the HWMF site. These measured exposure rates are conservative since they include the dose contribution from radioactive sources other than that those in the soil, i.e., the legacy radioactive waste that was stored outdoors and above ground. The majority, if not all of these radioactive sources (predominately legacy waste), are to be removed before remediation. The contribution from these sources cannot be easily subtracted at present. Therefore, a reassessment of the dose to present workers may be needed after the legacy waste is removed. It was also assumed that the dose from inhalation and ingestion of soil was negligible. Sampling of the three monitoring wells was assumed to continue for the remaining 50-year operational period plus a 30-year RCRA post-closure period. An integrated decay factor of 37.6 was used to account for the reduction of exposure rates over these 80 years.

The initial annual dose associated with security/safety inspections was estimated to be $0.438 \mathrm{mrem} / \mathrm{yr}$, since monthly grounds' inspections would require about one person-hour and the average exposure rate at the perimeter was $0.04 \mathrm{mR} / \mathrm{hr}(0.913 \mathrm{mrem} / \mathrm{mR}$ conversion factor). Multiplying by the integrated decay-correction factor of 37.63 to integrate the dose from cesium137 ground contamination from $t_{1}=0$ and $t_{2}=80$ equates to $16 \mathrm{mrem}$ or 0.016 person-rem. In addition, it was assumed that there was no grass to mow at the HWMF site. No repairs to the fence nor to the abandoned structures were assumed to be performed here.

\subsubsection{Calculations and Results}

The dose to the present workers, i.e., before BNL's site closure, based on the current radiological conditions were calculated using the following equation:

$$
\Sigma \mathrm{CD}_{\mathrm{wi}}=\mathrm{D}_{\mathrm{x}} \times \dot{\mathrm{X}} \times \mathrm{IDC} \times \mathrm{ST} \times \mathrm{NPE} \times \mathrm{SF}
$$

where,

$\mathrm{CD}_{\mathrm{wi}}$ collective dose with initial radiological conditions (person-rem), per well

$D_{x} \quad$ exposure in air to effective dose in tissue conversion factor 0.913 for cesium-137 $(\mathrm{mrem} / \mathrm{mR})$

$\dot{\mathrm{X}}$ measured exposure rate or projected dose rate at the monitoring well $(\mathrm{mR} / \mathrm{hr}$ or $\mathrm{mrem} / \mathrm{hr}$ ) 
IDC integrated decay correction factor to integrate dose from cesium-137 ground contamination from $t=t_{1}$ to $t=t_{2}$. For $t_{1}=0$ and $t_{2}=80$, this equates to 37.63 .

ST sampling time for a BNL monitoring well is about 1 hour (Lagattolla 1996).

NPE number of persons exposed, 2 persons sampling the wells (Lagattolla 1996).

SF sampling frequency: quarterly sampling or 4 samples per year (Lagattolla 1996).

Appendix D has the spreadsheet calculations for the collective dose to present workers without remediation. The collective dose to BNL's present workers to sample the three monitoring wells (4.32 person-rem) and carry out ground security/safety inspections $(0.016$ person-rem) at the HWMF was estimated to be about 4.34 person-rem based on the current radiological conditions.

\subsubsection{Dose to Present Workers after Remediation}

\subsubsection{Radiation Exposure Scenario}

The two environmental-monitoring technicians would have lower radiation doses from quarterly sampling of the three monitoring wells if the contaminated soil were excavated and stored off-site. The radiation exposure rates around the well were restored to the following riskbased remediation goals/limit $1,15,25,75$, or the $100 \mathrm{mrem} / \mathrm{yr}$ limit. To estimate the dose to present workers after environmental remediation, it was assumed that the environmental remediation would be completed in 1999.

A security guard was assumed to inspect the fenced-in area monthly, on the average, for one hour per month. The average exposure rate that was measured while walking the perimeter of the fence was $0.04 \mathrm{mR} / \mathrm{hr}$ at waist level. These exposure rates were measured on 01/31/97 using a tissue-equivalent beta scintillator calibrated within the past year to cesium-137 (Dionne 1997).

\subsubsection{Assumptions}

Remediation at the HWMF would finish in 1999, but the sampling of the three monitoring wells was assumed to continue for the remaining 48-year operational period (assumes that remedial action is completed after 2 years, i.e., 1999) plus 30 years post-closure. The lower radiation exposure rates following remediation would reduce the workers' exposures when collecting environmental samples over this 78-year period. The corresponding residence time for workers to this location was $298 \mathrm{hr} / \mathrm{y}$. Since external exposure is the major pathway, the 
corresponding adjusted hourly dose rates for the $1,15,25,75 \mathrm{mrem} / \mathrm{yr}$ risk-based remediation goals/limit and the $100 \mathrm{mrem} / \mathrm{yr}$ limit yields $0.003(1 \mathrm{mrem} / \mathrm{hr} / 298 \mathrm{hr} / \mathrm{yr}), 0.05,0.09,0.25$, and $0.33 \mathrm{mrem} / \mathrm{hr}$, respectively. Reduction of radionuclide concentrations in the soil from erosion or leaching was considered negligible.

Using the DCGL as the dose rate was a conservative assumption, since most environmental remediation efforts conducted to date at radiation cleanup sites (excluding some uranium-mill tailings (UMTRA)) have returned the radiation dose rates to well below the remedial goals. In fact, most remedial actions at UMTRA sites have restored ambient dose rates to near background levels.

\subsubsection{Calculations and Results}

The doses to the present workers after environmental remediation were calculated using the same equation (1) that was used for the present worker before remediation. The values that were changed were hourly exposure rates, exposure time, and the decay factor. The hourly exposures rates at each of the three wells after remediation was $0.003,0.05,0.09,0.25$ and 0.33 $\mathrm{mrem} / \mathrm{hr}$, for the $1,15,25,75 \mathrm{mrem} / \mathrm{yr}$ risk-based remediation goals/limit and the $100 \mathrm{mrem} / \mathrm{yr}$ limit, respectively. The period of exposure was reduced from 80 years to 78 years. Also, an integrated decay factor of 35.68 was used to account for the reduction of exposure rate over this period. The collective dose to the sampling team and security guard during 1997 and 1998 was calculated as described in Section 2.1.1.3 with the exception that the integrated decay factor was replaced with 2 for this two year period.

The initial annual dose associated with security inspections was estimated to be $0.438 \mathrm{mrem} / \mathrm{yr}$, since monthly grounds inspections would require about one person-hour and the average perimeter exposure rate was $0.04 \mathrm{mR} / \mathrm{hr}$. Multiplying by the integrated decay correction factor of 37.63 to integrate dose from cesium- 137 ground-contamination from $t_{1}=0$ and $t_{2}=80$ and $0.913 \mathrm{mrem} / \mathrm{mR}$ conversion factor equates to $16 \mathrm{mrem}$ or 0.016 person-rem. In addition, it was assumed that there was no grass to mow at the HWMF site. No repairs to the fence nor to the abandoned structures were assumed to be performed.

Appendix $\mathrm{D}$ has the spreadsheet calculations for the collective dose to present workers after environmental remediation. The collective doses to sample the monitoring wells and for grounds security/safety inspections at the HWMF were estimated to be 0.243 person-rem at $1 \mathrm{mrem} / \mathrm{yr}$ remediation goal, 0.283 person-rem at $15 \mathrm{mrem} / \mathrm{yr}, 0.326$ person-rem at 25 $\mathrm{mrem} / \mathrm{yr}, 0.454$ person-rem at $75 \mathrm{mrem} / \mathrm{yr}$, and 0.523 person-rem at the $100 \mathrm{mrem} / \mathrm{yr}$ dose limit; these are summarized in the Table 2.1-2. 
Table 2.1-2 Collective Dose to Present Workers after Remediation

\begin{tabular}{|c|c|}
\hline $\begin{array}{c}\text { Risk-based Remediation } \\
\text { Goals/Limit (mrem/yr) }\end{array}$ & $\begin{array}{c}\text { Collective Dose: } \\
\text { Workers After Remediation } \\
\text { (person-rem) }\end{array}$ \\
\hline \hline 1 & 0.243 \\
\hline 15 & 0.283 \\
\hline 25 & 0.326 \\
\hline 75 & 0.454 \\
\hline 100 & 0.523 \\
\hline
\end{tabular}

\subsubsection{Dose to Workers Excavating, Packaging, and Storing Soil On-Site}

\subsubsection{Radiation Exposure Scenario}

During a site remediation, workers are exposed to both direct radiation and inhalation of airborne radioactive dust, i.e., fugitive dust. A key parameter in calculating the cumulative dose to workers was the cumulative effort required to remediate a unit volume of contaminated soil. In this dose assessment, remediation was considered to consist solely of excavating the soil, packaging it in B-25 containers, and transferring it to the new HWMF for temporary storage, i.e., less than six months. This new HWMF, which commenced operation in 1997, was built to meet NYS regulations which implement the requirements in the Resource Conservation and Recovery Act (RCRA).

This assessment also assumes that the exposure rates have been restored to the following risk-based remediation goals/limit $1,15,25,75 \mathrm{mrem} / \mathrm{yr}$ and the $100 \mathrm{mrem} / \mathrm{yr}$ limit. These goals translated into the following derived concentration guideline levels for the undeveloped open-space scenario following 50 years of Federal control: 15, 230, 380, 1135, and $1500 \mathrm{pCi} / \mathrm{g}$ for cesium-137, respectively (see Appendix A, first column, for details on the RESRAD pathways/parameters used, and Appendix $B$ for the associated RESRAD printouts). These risk-based remediation goals/limit required excavating the following soil volumes: 78,000 $\left(60,000 \mathrm{~m}^{3}\right) ; 26,000\left(20,000 \mathrm{~m}^{3}\right) ; 20,000\left(15,000 \mathrm{~m}^{3}\right) ; 9,000\left(7,000 \mathrm{~m}^{3}\right)$, and $8,000\left(6,100 \mathrm{~m}^{3}\right)$ cubic yards, respectively. The resulting volume-weighted geometric average concentrations and volume-weighted arithmetic average concentrations were used for the lower- and upper-end dose estimates (see Appendix $\mathrm{C}$ for details of the volumes of soil and radionuclide concentrations). 


\subsubsection{Assumptions}

The assessments were based on an assumed 1.62 person-hours to excavate, monitor, package, and handle one cubic meter of soil (USNRC 1997 Addendum 1 of NUREG 1496, which was, in part, based on the "Superfund Record of Decision: Monticello Mill Tailings," EPA/ROD/ROD-90/034, August 1990). This Monticello labor estimate assumed local on-site storage of waste packages. The BNL HWMF scenario assumes that the soil will be stored for less than six months at the new HWMF and not the old HWMF. Therefore, the collective dose associated with transport from the old HWMF to the new HWMF (approximately 1 mile), as well as the collective dose associated with temporary storage of the packaged soil at the new HWMF must also be calculated.

The inhalation dose was based on a dust loading of $400 \mu \mathrm{g} / \mathrm{m}^{3}$ during excavation. The outdoor dust loading was highly variable depending on the properties of the soil (especially moisture content), wind speed, and activities that could suspend the dust. A study by the U.S. Nuclear Regulatory Commission (NRC) indicates that it can vary from about ten to several hundred micrograms $/ \mathrm{m}^{3}$ (USNRC 1992). For a site with heavy industrial activity, it was not unusual for the dust loading to exceed several hundred micrograms $/ \mathrm{m}^{3}$ and all dust particles to be of respirable size. The Occupational Safety and Health Administration (OSHA) standard for nuisance dust in the workplace is 10,000 micrograms $/ \mathrm{m}^{3}$, but the dust level can be maintained well below this level by using dust-suppression techniques, such as wetting the soil with a fine mist.

Another consideration in modeling dust inhalation was the concentration enhancement or discrimination factor. It was assumed that the concentration of the radionuclide in the dust was the same as in the soil. Studies have shown that, in some cases, and for some contaminants, the concentration of the radionuclides in dust can be either higher (enhancement) or lower (discrimination) than the concentration in the soil. For example, windblown suspension picks up the smaller, lower-density soil particles, typically less than 50 microns in diameter (USNRC 1993). Hence, if the contaminants adhere to soil particles smaller than 50 microns, more radioactive particles will be suspended. If the radionuclides preferentially adhere to the very small particles, enhancement can occur. The converse is also true. Due to a lack of site-specific data for this parameter, no enhancement or discrimination factor was used.

All remediation workers at BNL who move soil containing hazardous substances are required to wear a half-face respirator. Studies conducted by the NRC at Sandia National Laboratory established a protection factor of 0.1 for half-face respirators (USNRC 1976). External and inhalation dose-conversion factors were taken from EPA 402-R-93-081, Federal Guidance Report No. 12 entitled "External Exposure to Radionuclides in Air, Water and Soil" (USEPA 1993a) and EPA-520/1-80-020, Federal Guidance Report 11 entitled "Limiting Values of Radionuclide Intake and Air Concentration and Dose Conversion Factors for Inhalation, Submersion, and Ingestion" (USEPA 1988a), respectively. 
The doses to disposal workers associated with transporting of the B-25 containers from the old HWMF to the new HWMF (approximately 1 mile) and temporary storage there for less than six months were also calculated. The dose assessment calculations were based on a timeand-motion study of a fork-truck driver. It was further assumed that four disposal workers would be handling and inspecting the soil packages, but that only the fork truck driver received a measurable dose. In addition, since the higher concentration soil $(>2,800 \mathrm{pCi} / \mathrm{g})$ is to be stabilized using an automated grouting and packaging system, the collective dose associated with this operation was considered negligible. The collective dose associated with RCRA inspections of this hazardous waste during on-site storage was considered negligible.

The average time for a fork-truck driver to pick up a B-25 container and load it onto or offload it from a truck or the ground was about one minute. Therefore, the total time associated with picking up and putting down the B-25 container at the packaging station at the old HWMF, at the truck at the old HWMF, at the truck at the entrance to the new HWMF waste storage facility, and inside the new HWMF waste storage facility was 4 minutes $(0.066 \mathrm{hr})$. It was also assumed that on the fork-truck driver would be exposed from radiation from an array of four B-25 packages while picking up the B 25 container with the fork truck. The average velocity of the fork truck during transit was $425 \mathrm{ft} . / \mathrm{min}$. The average distances from the old HWMF excavation/packaging location to the truck was $300 \mathrm{ft}(0.706 \mathrm{~min}$. or 0.012 hours). The average distances from the truck to the storage location inside the new HWMF waste storage facility was $200 \mathrm{ft}$. (0.468 $\mathrm{min}$. or 0.008 hours). The total transit time for the fork-truck driver is 1.17 minutes( 0.02 hours $)$. The top of the fork-truck driver's head was, on the average, $6 \mathrm{ft}$ from the side of the B- 25 container.

The dose to the truck driver who transports four B 25 containers via a BNL flatbed truck from the old HWMF to the new HWMF also was calculated. The transit time for this 1 mile trip to the new HWMF was $5 \mathrm{~min}$.(0.083 hour) In addition, the distance to the driver from the sides of the B-25 containers is about $12 \mathrm{ft}$. The Microshield calculations for the dose rates per $\mathrm{pCi} / \mathrm{g}$ to the driver was similar to that described in Section 2.1.4.

\subsubsection{Calculations and Results}

The collective doses attributable to inhalation of suspended dust, $C D_{\text {Inh }}$, were determined as follows (see Appendix D spreadsheets):

$$
\mathrm{CD}_{\text {Inh }}=\mathrm{RSC} \times \mathrm{DCF}_{\operatorname{Inh}} \times \mathrm{IR} \times 1.62 \times \text { VOL } \times \text { DL } \times 0.1 \times 0.001
$$


where,

$$
\begin{aligned}
& \mathrm{CD}_{\text {Inh }}=\quad \text { cumulative effective collective-dose commitment to workers } \\
& \text { from inhaling the suspended dust (person-rem) } \\
& \mathrm{RSC}=\text { average radionuclide concentration of excavated soil } \\
& \text { (pCi/g) } \\
& \mathrm{DCF}_{\text {Inh }}=\quad \text { inhalation dose conversion factor for cesium-137 of } 3.2 \times 10^{-5} \text { and } \\
& \text { strontium-90 of } 1.3 \times 10^{-3}(\mathrm{mrem} / \mathrm{pCi}) \text { (USEPA 1988a) } \\
& \text { IR }=\text { inhalation rate of } 1.2 \mathrm{~m}^{3} / \mathrm{hr} \\
& 1.62=\text { person-hour to excavate and package } 1 \mathrm{~m}^{3} \text { of soil (USNRC 1997) } \\
& \text { VOL }=\quad \text { volume of excavated soil }\left(\mathrm{m}^{3}\right) \\
& \mathrm{DL}=\text { airborne dust-loading } 0.0004 \mathrm{~g} / \mathrm{m}^{3} \text { (USNRC 1992) } \\
& 0.1=\text { respirator protection factor, half-face respirator } \\
& \text { (USNRC 1976) } \\
& 0.001=\text { mrem to person-rem conversion factor }
\end{aligned}
$$

The collective doses attributable to external radiation exposure, $\mathrm{CD}_{\mathrm{Ex}}$, were determined as follows (see Appendix D spreadsheets):

$$
\mathrm{CD}_{\mathrm{Ext}}=\mathrm{RSC} \times \mathrm{DCF}_{\mathrm{Ext}} \times \frac{\mathrm{SD}}{1.6} \times 1.62 \times \mathrm{VOL} \times 0.000114 \times 0.001
$$

where:

$$
\begin{aligned}
& \mathrm{CD}_{\mathrm{Ext}}=\quad \text { cumulative worker-collective-dose from external radiation received } \\
& \text { during excavating, packaging, and handling (person-rem) } \\
& \mathrm{DCF}_{\mathrm{Ext}}=\quad \text { external dose conversion factor for cesium-137 of } 3.605 \text { (mrem/yr } \\
& \text { per pCi/g) (USEPA 1993a) } \\
& \mathrm{SD}=\quad \text { soil density of } 1.66 \mathrm{~g} / \mathrm{cm}^{3}(\mathrm{CDM} 1991) \\
& 1.6=\text { soil density used in external dose conversion factor (USEPA } \\
& \text { 1993a) } \\
& 0.000114=\text { conversion factor, person hours to years }
\end{aligned}
$$


Radiation dose rates were calculated for BNL's fork-truck driver during pick up and transit operations at BNL. These calculations were performed using the Microshield 5.01 computer code developed by Grove Engineering of Rockville, Maryland. The printouts in Appendix $\mathrm{E}$ show that the average dose rates to the fork-truck driver during pick up of the container are $2.98 \mathrm{E}-04$ millirem $/ \mathrm{hr}$ per pCi/g of cesium-137 for Fluor Daniels Solid Waste Disposal Site shipments, and $4.15 \mathrm{E}-04 \mathrm{millirem} / \mathrm{hr}$ per $\mathrm{pCi} / \mathrm{g}$ of cesium-137 for Envirocare shipments $(6 \mathrm{ft}$. from the four B-25 containers on the low-bed trailer or array of B-25 containers at the packaging station or waste storage facility). The printouts in Appendix $E$ show that the average dose rates to the BNL fork-truck driver during transit with one B 25 container are 1.28 E-04 millirem $/ \mathrm{hr}$ per pCi/g of cesium-137 for Fluor Daniels Solid Waste Disposal Site shipments and $1.76 \mathrm{E}-04 \mathrm{microrem} / \mathrm{hr}$ per $\mathrm{pCi} / \mathrm{g}$ of cesium- 137 for Envirocare shipments $(6 \mathrm{ft}$. from the B25 container on the fork truck).

Radiation dose rates were calculated for BNL's truck driver that transports the four B 25 containers from the old HWMF to the new HWMF. These calculations also were performed using the Microshield 5.01 computer code. The printouts in Appendix E show that the average dose rates to the truck driver during transport to the new HWMF are 7.62 E-06 millirem $/ \mathrm{hr}$ per pCi/g of cesium-137 for Fluor Daniels Solid Waste Disposal Site shipments, and $1.07 \mathrm{E}-05 \mathrm{millirem} / \mathrm{hr}$ per $\mathrm{pCi} / \mathrm{g}$ of cesium- 137 for Envirocare shipments (12 ft. from the four B25 containers on the low-bed trailer) The volume-weighted geometric and arithmetic average concentrations used for the Fluor Daniels Solid Waste Disposal Site shipments and Envirocare shipments are shown on the spreadsheet in Appendix E. The collective doses to these disposal workers are summarized in Table 2.1-3.

The collective doses to workers from excavating, transporting, storing, and performing Resource Conservation and Recovery Act (RCRA) inspections of the contaminated soil from the HWMF were calculated using the geometric and arithmetic average concentrations. The lower- and upper-dose assessments showed that $10-203$ person-rem will be required at 1 $\mathrm{mrem} / \mathrm{yr}$ risk-based remediation goals/limit, $17-199$ person-rem at $15 \mathrm{mrem} / \mathrm{yr}, 20-199$ personrem at $25 \mathrm{mrem} / \mathrm{yr}, 29-195$ person-rem at $75 \mathrm{mrem} / \mathrm{yr}$, and $32-194$ person-rem at $100 \mathrm{mrem} / \mathrm{yr}$ dose limit; these data are summarized in Table 2.1-3. 
Table 2.1-3 Collective Dose to Environmental Remediation Workers

\begin{tabular}{|c|c|c|c|c|}
\hline $\begin{array}{c}\text { Risk-Based } \\
\text { Remediation } \\
\text { Goals/Limit } \\
\text { (mrem/yr) }\end{array}$ & \multicolumn{4}{|c|}{$\begin{array}{c}\text { Volume-Weighted Geometric } \\
\text { and Arithmetic Average Soil Concentrations }\end{array}$} \\
\cline { 2 - 5 } & $\begin{array}{c}\text { Collective Dose: } \\
\text { Remedial Worker } \\
\text { Inhalation with } \\
\text { Half-Face } \\
\text { Respirators } \\
\text { (person-rem) }\end{array}$ & $\begin{array}{c}\text { Collective } \\
\text { Dose: } \\
\text { Remedial } \\
\text { Worker } \\
\text { External } \\
\text { (person- } \\
\text { rem) }\end{array}$ & $\begin{array}{c}\text { Collective } \\
\text { Dose: } \\
\text { BNL } \\
\text { Disposal } \\
\text { Worker } \\
\text { (person- } \\
\text { rem) }\end{array}$ & $\begin{array}{c}\text { Total } \\
\text { Collective Dose } \\
\text { to Remediation } \\
\text { Wisposal } \\
\text { Workers } \\
\text { (person-rem) }\end{array}$ \\
\hline \hline 1 & 5.78 E-05-8.63 E-04 & $10-200$ & $0.14-2.94$ & $10-203$ \\
\hline 15 & 9.26 E-05-8.48 E-04 & $17-196$ & $0.14-2.87$ & $17-199$ \\
\hline 25 & 1.09 E-04-8.43 E-04 & $20-196$ & $0.14-2.86$ & $20-199$ \\
\hline 75 & 1.62 E-04-8.26 E-04 & $29-192$ & $0.13-2.77$ & $29-195$ \\
\hline 100 & 1.76 E-04-8.23 E-04 & $32-191$ & $0.13-2.76$ & $32-194$ \\
\hline
\end{tabular}

\subsubsection{Dose to Drivers/Workers from Transporting and Disposing of the Soil Off- site}

\subsubsection{Radiation Exposure Scenario}

Workers can be exposed to radiation while handling, transferring, and inspecting the packages of contaminated soil. This occurs primarily during loading and transport to either Envirocare in Utah or Fluor Daniels Solid Waste Disposal Site in Washington, as well as during routine RCRA inspections associated with long-term storage at the treatment, storage, and disposal (TSD) facility. Radiological doses were determined during normal, incident-free transportation for occupational workers.

For truck shipments, the occupational workers were the site workers loading the trucks and the private carriers hauling the shipments from Upton, New York to Clive, Utah and Richland, Washington. Envirocare's waste acceptance criteria allow an average concentration for cesium- 137 of up to $560 \mathrm{pCi} / \mathrm{g}$. The waste management engineers from CDM Federal Program determined that this equates to a maximum concentration of $2,800 \mathrm{pCi} / \mathrm{g}$. In addition, $2,800 \mathrm{pCi} / \mathrm{g}$ is also the lower limit for cesium-137 for Type A material from Westinghouse Hanford's Waste 
Acceptance Criteria (WHC 1995). Above this limit, the waste must be stabilized if it is to be accepted at Fluor Daniels Solid Waste Disposal Site for disposal.

Therefore, the volume of soil with radionuclide concentrations below $2,800 \mathrm{pCi} / \mathrm{yr}$ will be transported to, and disposed of, at Envirocare. The volume of soil with radionuclide concentrations above $2,800 \mathrm{pCi} / \mathrm{g}$ will be stabilized in Portland cement, poured into B-25 steel containers, and sent via a sole-source vehicle to Fluor Daniels Solid Waste Disposal Site. Section 2.2.4 describes the dose assessment for the members of the public associated with transport and off-site disposal.

\subsubsection{Assumptions}

drivers:

The following assumptions were applied to the dose assessments for the truck

1. The two drivers that occupied the cab were located 12 feet from the nearest $B-25$ package. An 18-wheel tractor trailer hitched to a low-bed trailer was used for the shipments to Envirocare and Fluor Daniels Solid Waste Disposal Site. The truck's maximum payload was 40,000 pounds; this equated to a maximum of four B-25 packages $(12 \mathrm{CY})$ per vehicle.

2. Most of the radiation came from the cesium-137 gamma radiation emitted from the four B-25 packages on the flatbed. Each B-25 container had carbon-steel walls 3/16-inches thick which was assumed to be composed of $100 \%$ iron. The dimensions of each B-25 steel container were $4^{\prime} \times 4^{\prime} \times 6^{\prime}\left(96 \mathrm{ft}^{3}\right.$ or $\left.3 \mathrm{CY}\right)$. The B25 package maximum payload was 10,000 pounds.

3. The radiation buildup resulting from scatter was calculated for all the material between the source point and the dose point using the tabulated infinite-medium buildup factor for the selected reference material, i.e., the soil. The soil at BNL was assumed to be predominately sandy gravel, or silicon dioxide ( $82 \%$ by weight $\left.\mathrm{SiO}_{2}\right)$ and moisture $\left(18 \% \mathrm{H}_{2} \mathrm{O}\right.$ ) (USGS 1975) with a bulk density of $1.66 \mathrm{~g} / \mathrm{cm}^{3}$ (CDM 1991). The concrete was assumed to be $75 \%$ sand/gravel and $25 \%$ Portland Type I concrete (Norton 1997). The chemical composition was that of NBS concrete (Grove 1996) and is shown in Appendix E.

4. The posterior-anterior irradiation geometry of an anthropomorphic phantom (see Figure 2.1-1) from Publication 51 of the International Commission on Radiological Protection (ICRP 1987) was used to calculate the effective dose-equivalent rate.

5. The radioactive material was uniformly distributed in the soil. The volumeweighted geometric and arithmetic average concentrations that were used for the 
Fluor Daniels Solid Waste Disposal Site and Envirocare shipments are shown on the spreadsheet in Appendix E.

6. The travel time from Upton, New York to Fluor Daniels Solid Waste Disposal Site, Washington was 44 hours (AutoMap 2.02 Software - 2,806 miles at about 63 $\mathrm{mph}$ ), and 35 hours to Givens, Utah (AutoMap 2.02 Software - 2,245 miles at about $65 \mathrm{mph}$ ). The average truck speed included the time spent in traffic jams.

7. The number of trips in Table 2.1-4 was determined using the volumes in Appendix $\mathrm{C}$, and a vehicle payload of $12 \mathrm{CY}$.

Table 2.1-4 Volumes of Soil that Require Off-Site Disposal and Number of Trips to the Fluor Daniels and Envirocare Waste Disposal Sites

\begin{tabular}{|c|c|c|c|c|}
\hline $\begin{array}{c}\text { Risk-Based } \\
\text { Goals/Limit } \\
(\mathbf{m r e m} / \mathbf{y r})\end{array}$ & $\begin{array}{c}\text { Fluor Daniels } \\
\text { Volumes } \\
(\mathbf{2}, \mathbf{8 0 0} \mathbf{~ p i / g )} \\
\mathbf{C Y}\end{array}$ & $\begin{array}{c}\text { Envirocare } \\
\text { Volumes } \\
\mathbf{( S C G} \text { to } \\
\mathbf{2 , 8 0 0} \mathbf{~ p C i / g )} \\
\mathbf{C Y}\end{array}$ & $\begin{array}{c}\text { Number of } \\
\text { Trips to } \\
\text { Fluor } \\
\text { Daniels }\end{array}$ & $\begin{array}{c}\text { Number of } \\
\text { Trips to } \\
\text { Envirocare }\end{array}$ \\
\hline \hline 1 & 5,980 & 72,312 & 498 & 6,026 \\
\hline 15 & 5,980 & 19,770 & 498 & 1,648 \\
\hline 25 & 5,980 & 14,220 & 498 & 1,185 \\
\hline 75 & 5,980 & 3,010 & 498 & 250 \\
\hline 100 & 5,980 & 2,020 & 498 & 168 \\
\hline
\end{tabular}

The collective doses to disposal workers associated with transporting the B-25 containers from temporary storage at the new HWMF to the Envirocare or Fluor Daniels disposal trenches (approximately $30 \mathrm{ft}$ ) were also calculated. The dose assessments were based on a timeand motion-study of a fork-truck driver picking up a B-25 container ( 1 minute), the average distances from the inside of the new HWMF waste storage facility to commercial flatbed truck in the parking lot( approximately $200 \mathrm{ft}$ ), the average distance from the truck to the Envirocare or Fluor Daniels disposal trenches (approximately $30 \mathrm{ft}$ ) and the average velocity of the fork truck during transit( $425 \mathrm{ft} / \mathrm{min}$ ). It was further assumed that four disposal workers would be handling and inspecting the soil packages, but that only the fork-truck driver received measurable dose. The collective dose associated with RCRA inspections of this hazardous waste after burial was considered negligible. 
The average time for a fork-truck driver to pick up a B-25 container and load it onto or offload it from a truck or the ground was about one minute. Therefore, the total time associated with picking up the B-25 container inside the new HWMF waste storage facility, on the truck in the parking lot at this facility, at the truck at the off-site disposal facility, and at the waste disposal trench was 4 minutes $(0.066 \mathrm{hr})$. It was also assumed that, on the average, the fork-truck driver at BNL and the other at the disposal site would be exposed from radiation from an array of four B-25 packages while picking them up. The average velocity of the fork truck during transit was $425 \mathrm{ft} . / \mathrm{min}$. The average distance from the storage location inside BNL's new HWMF to the commercial flatbed truck in the parking lot was $200 \mathrm{ft}$. $(0.468 \mathrm{~min}$. or 0.008 hours). The average distances from the commercial flatbed truck to waste storage trench was 30 ft. $(0.07 \mathrm{~min}$. or 0.001 hours $)$. The total transit time for the BNL and the second off-site fork truck drivers was 0.54 minutes ( 0.009 hours). It was assumed that the waste disposal truck will be driven into the waste-disposal trenches and that the row of B 25 containers would be backfilled with dirt after each row is laid. The top of the fork-truck drivers head was on the average $6 \mathrm{ft}$ from the side of the B-25 container. The dose to the commercial truck driver was assumed to be minimal, since the driver did not loiter near the trench during disposal operations.

\subsubsection{Calculations and Results}

Radiation dose rates were calculated for the waste shipment drivers during transit to the off-site disposal facilities. Calculations were performed using the Microshield 5.01 computer code developed by Grove Engineering of Rockville, Maryland (Grove 1996). The printouts in Appendix E show that the average dose rates in the truck cab are $7.60 \mathrm{microrem} / \mathrm{hr}$ per $\mathrm{pCi} / \mathrm{g}$ of cesium-137 for Fluor Daniels Solid Waste Disposal Site shipments and 10.7 microrem $/ \mathrm{hr}$ per $\mathrm{pCi} / \mathrm{g}$ of cesium-137 for Envirocare shipments ( $12 \mathrm{ft}$. from the four B-25 containers on the low-bed trailer).

Radiation dose rates were also calculated for the BNL and off-site fork-truck drivers during picking up and transporting the soil to the off-site waste disposal trench. These calculations were performed using the Microshield 5.01 computer code. The printouts in Appendix E show that the average dose rates to the BNL and off-site fork-truck driver during pick up of the container are $2.98 \mathrm{E}-04 \mathrm{millirem} / \mathrm{hr}$ per pCi/g of cesium-137 for Fluor Daniels Solid Waste Disposal Site shipments, and $4.15 \mathrm{E}-04 \mathrm{millirem} / \mathrm{hr}$ per pCi/g of cesium-137 for Envirocare shipments ( $6 \mathrm{ft}$. from the four B-25 containers on the side of the low-bed trailer or $6 \mathrm{ft}$. from the row of four B-25 containers at the off-site waste storage facility). The printouts also show that the average dose rates to the $\mathrm{BNL}$ and off-site fork-truck driver during transit are $1.28 \mathrm{E}-04$ millirem $/ \mathrm{hr}$ per $\mathrm{pCi} / \mathrm{g}$ of cesium-137 for Fluor Daniels Solid Waste Disposal Site shipments and $1.76 \mathrm{E}-04 \mathrm{millirem} / \mathrm{hr}$ per pCi $/ \mathrm{g}$ of cesium- 137 for Envirocare shipments $(6 \mathrm{ft}$. from the B-25 container on the fork truck). The volume-weighted geometric and arithmetic average concentrations used for the Fluor Daniels Solid Waste Disposal Site shipments and Envirocare shipments are shown on the spreadsheet in Appendix E. The collective doses to the off-site disposal workers are summarized in Table 2.1-5. 
Figure 2.1-1 Irradiation Geometries with an Anthropomorphic Phantom Used in Calculating the Dose Equivalent from External Radiation (ICRP 1987)
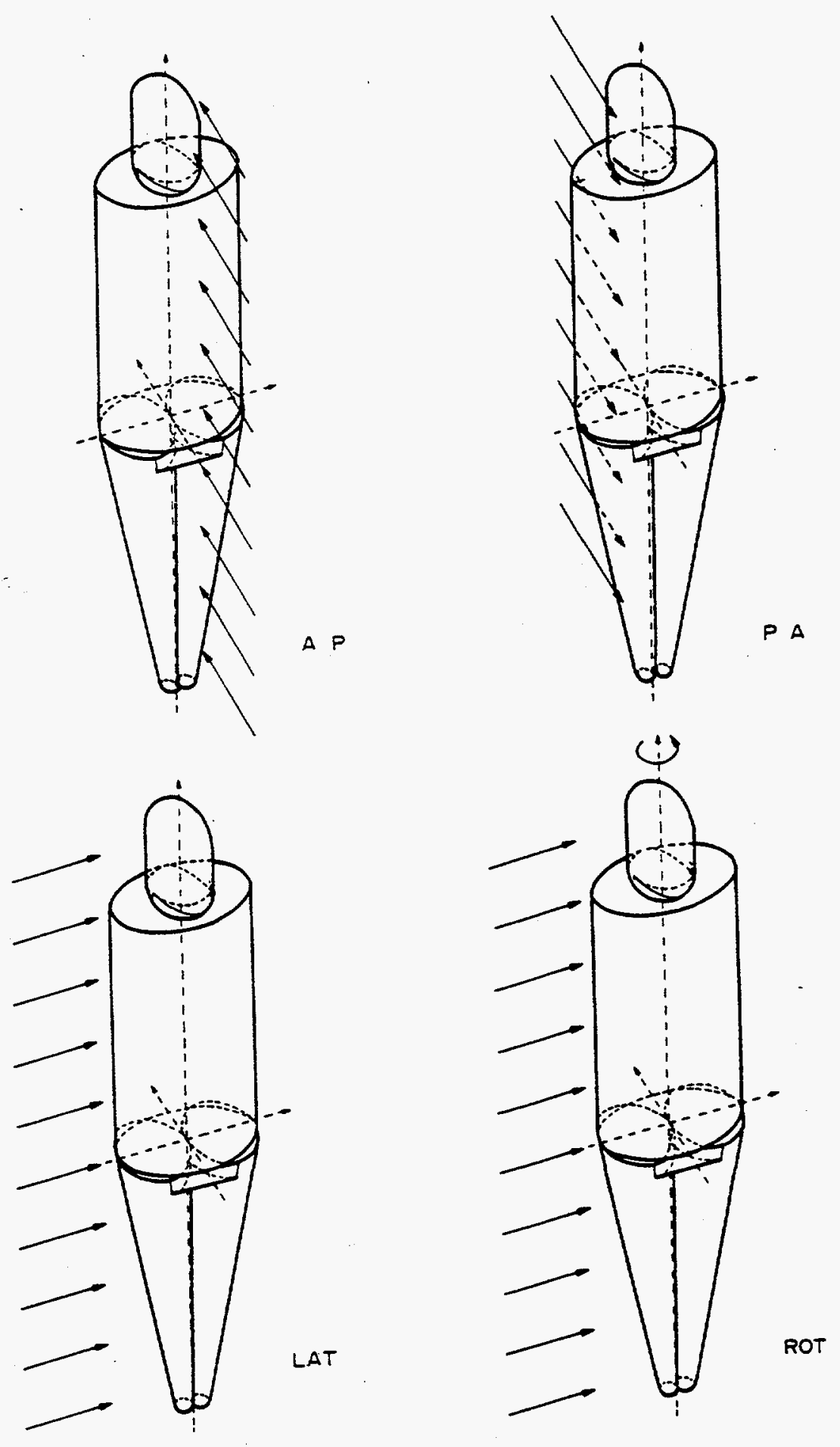
The collective dose to drivers/workers waste handling, transporting, disposing, and inspecting of the waste was calculated to be $0.94-19.6$ person-rem at $1 \mathrm{mrem} / \mathrm{yr}$ risk-based remediation goals/limit, $0.92-19.2$ person-rem at $15 \mathrm{mrem} / \mathrm{yr}, 0.91-19.1$ person-rem at 25 $\mathrm{mrem} / \mathrm{yr}, 0.88-18.4$ person-rem at $75 \mathrm{mrem} / \mathrm{yr}$, and $0.87-18.3$ person-rem at $100 \mathrm{mrem} / \mathrm{yr}$ dose limit. These data are summarized in Table 2.1-5.

Table 2.1-5 Collective Dose to Drivers/Workers from Transport and Off-Site Disposal

\begin{tabular}{|c|c|c|c|}
\hline \multirow{2}{*}{$\begin{array}{c}\text { Risk-Based } \\
\text { Remediation } \\
\text { Goals/Limit } \\
\text { (mrem/yr) }\end{array}$} & \multicolumn{3}{|c|}{$\begin{array}{c}\text { Volume Weighted Geometric } \\
\text { and Arithmetic Average Soil Concentrations }\end{array}$} \\
\cline { 2 - 4 } & $\begin{array}{c}\text { Collective Dose: } \\
\text { Truck Drivers } \\
\text { (person-rem) }\end{array}$ & $\begin{array}{c}\text { Collective Dose: } \\
\text { BNL \& Off-site } \\
\text { Disposal Workers } \\
\text { (person-rem) }\end{array}$ & $\begin{array}{c}\text { Collective Dose: } \\
\text { Transport and } \\
\text { Disposal Workers } \\
\text { (person-rem) }\end{array}$ \\
\hline \hline 1 & $0.83-17.4$ & $0.106-2.21$ & $0.94-19.6$ \\
\hline 15 & $0.82-17.1$ & $0.103-2.15$ & $0.92-19.2$ \\
\hline 25 & $0.81-17.0$ & $0.102-2.14$ & $0.91-19.1$ \\
\hline 75 & $0.78-16.4$ & $0.099-2.05$ & $0.88-18.4$ \\
\hline 100 & $0.78-16.3$ & $0.098-2.04$ & $0.87-18.3$ \\
\hline
\end{tabular}

\subsubsection{Dose Averted or Expended to Present Workers: Summary}

In summary, the results show that the potential radiation dose impacts to workers resulting from excavation and disposal of contaminated soil off-site are about two orders of magnitude greater than the dose savings to workers that would result from remediation. The worker's dose assessments in Sections 2.1.1 through 2.1.4 showed that net collective doses of -219 person-rem would result from remediation to the $1 \mathrm{mrem} / \mathrm{yr}$ guideline, -214 person-rem to the $15 \mathrm{mrem} / \mathrm{yr},-214$ person-rem to the $25 \mathrm{mrem} / \mathrm{yr},-209$ person-rem to the $75 \mathrm{mrem} / \mathrm{yr}$, and -208 person-rem to the $100 \mathrm{mrem} / \mathrm{yr}$ limit. Therefore, the potential radiological impacts to workers associated with the excavation, transport and disposal off-site were much greater than the present worker dose savings that would result from remediation. Table 2.1-6 summarizes the estimated savings, impacts, and the averted or expended (negative) collective doses from remediation of the HWMF. 
Table 2.1-6 Collective Dose Averted or Expended to Present Workers: Summary

\begin{tabular}{|c|c|c|c|}
\hline $\begin{array}{c}\text { Risk-based } \\
\text { Remediation } \\
\text { Goals/Limit } \\
\text { (mrem/yr) }\end{array}$ & $\begin{array}{c}\text { Worker Collective } \\
\text { Dose Savings } \\
\text { (person-rem) }\end{array}$ & $\begin{array}{c}\text { Worker Collective } \\
\text { Dose Impacts } \\
\text { (person-rem) }\end{array}$ & $\begin{array}{c}\text { Net Collective Dose } \\
\text { to Workers } \\
\text { (person-rem) }\end{array}$ \\
\hline \hline 1 & 4.09 & -223 & -219 \\
\hline 15 & 4.05 & -218 & -214 \\
\hline 25 & 4.01 & -218 & -214 \\
\hline 75 & 3.88 & -213 & -209 \\
\hline 100 & 3.81 & -212 & -208 \\
\hline
\end{tabular}

\subsection{Dose Averted or Expended to Future Members of the Public}

\subsubsection{Dose to Future Visitors to this Open Space from Existing Radiological Conditions}

\subsubsection{Radiation Exposure Scenario}

Thirty visitors per year were assumed to use the former HWMF site after BNL's 50-year Federal control period ended in 2047. Families or individuals spent about four hours per visit or an estimated 2.5 annual visitors per acre $\left(600\right.$ annual visitors $\left./ \mathrm{km}^{2}\right)$. This is an average of 1.6 visitors $/$ day $/ \mathrm{km}^{2}$. This is the average of the NYS Rocky Point Natural Resources Management Area (5,154 acres, 15,000 visitors/year) and the Navy Cooperative area $(4,026$ acres, 8,000 visitors/year). The BNL site is located close (tens of miles) to these two properties and should have similar uses. In both cases, the visitors' activities are hunting, hiking, nature observation, and cross-country skiing. Access permits are required for the Rocky Point Property; 4,000 are issued annually. If 5,000 people are assumed to use the BNL property, 15,000 visits $/ 5,000$ people $=3$ days per year per person. The number of visitor-days to BNL may be an overestimate. However, an increasing population in the surrounding area is likely to increase overall visits (Meinhold 1997). These visitors could collect and consume mushrooms and berries harvested from the site. These visitors could also consume deer meat that may feed on the vegetation from this site.

The RESRAD parameters that were used for the dose assessment to visitors using the undeveloped open-space scenario are presented in Appendix A - RESRAD Pathways/Parameters for Hazardous Waste Management Facility: (HWMF) Soil Remediation Guidelines, Soil to Water Screening Levels, and Dose to Open Space Visitors, columns 3 and 4. These visitors were exposed to two source terms and, consequently, two separate RESRAD computer runs were performed: (1) the dose from the first foot of soil ( $0-1 \mathrm{ft})$, and (2) the dose from the buried soil (1-12 ft). Appendix C - Hazardous Waste Management Facility (HWMF): 
Soil Volumes and Radionuclide Concentrations, gives the areas, depths, and length parallel to aquifer flow used for these two depth intervals. The volume-weighted geometric average concentrations and volume-weighted arithmetic average concentrations that were used for the lower- and upper-end dose estimates are given in Appendix F. Average individual dose parameters were used to project the collective dose to visitors from the year 2047 to 2317 (see Appendix A).

\subsubsection{Assumptions}

The RESRAD 5.61 pathway analysis models were used to calculate potential radiation doses and risks using the following assumptions:

1. An area of $1.932 \mathrm{E}+04 \mathrm{~m}^{2}$ was homogeneously contaminated to a thickness of $0.3048 \mathrm{~m}$ (1 foot). This was used for the first foot of soil source-term. An area of $6.80 \mathrm{E} 03 \mathrm{~m}^{2}$ with a thickness of $3.52 \mathrm{~m}$ (11 feet) was used for the buried soil source-term. This later source term also assumed to have a 1 foot soil cover. The length parallel to aquifer flow was $161 \mathrm{~m}$ for the first foot of soil and $64 \mathrm{~m}$ for the buried dirt. A soil bulk density of $1.66 \mathrm{~g} / \mathrm{cm}^{3}$ was used (CDM 1991).

2. The thirty visitors to the open space spent 3 days per year for 30 years over a 270- year period (nine half-lives for cesium-137) (Meinhold 1997).

3. No reduction factor for radiation shielding afforded by building materials was used for the visitors to the open space, since all exposure occurs outdoors (Meinhold 1997).

4. No indoor ventilation reduction factor for inhalation was used for the visitors to the open space, since all exposure occurs outdoors (Meinhold 1997). The assumed-open space inhalation rate for the average visitor was $1.7 \mathrm{~m}^{3} / \mathrm{hr} x$ $8,760 \mathrm{hrs} / \mathrm{yr}=14,892$ or $1.5 \mathrm{E}+04 \mathrm{~m}^{3} / \mathrm{yr}$ (Meinhold 1997).

5. The average visitor's annual intake of soil was assumed to be $18 \mathrm{~g} / \mathrm{yr}$ total both on-site and off-site. An outdoor fraction was applied by the RESRAD software application to this value to account for possible ingestion of soil at the HWMF site (Meinhold 1997).

6. The average visitor consumed berries and mushrooms collected on-site. The RESRAD default of $160 \mathrm{~kg} / \mathrm{yr}$ was used for the ingestion rate of vegetables, fruit, and grains. The contaminated fraction of fruits, vegetables, and grains was 0.0003 or $1 \mathrm{~kg} / \mathrm{yr}$ (Meinhold 1997). The ingestion of approximately two pounds of berries and mushrooms by each of the 30 visitors is very conservative. No leafy vegetables were consumed.

7. The visitors did not consume site groundwater. 
8. No meat or milk from animals raised on-site was ingested by visitors except venison. Game animals, e.g., deer living on the decontaminated site, cannot now be taken by the public. However, to account for the possibility of poaching, or that hunting may be allowed in the future, a conservative assumption was made that the average visitor consumed between 1.35 to 8.85 $\mathrm{kg} / \mathrm{yr}$ (midpoint $=5.1 \mathrm{~kg}$ or about eleven pounds) of deer meat (Davis 1995). The annual intake of beef, pork, and other meat was $51.1 \mathrm{~kg} / \mathrm{yr}$, only $20 \%$ of the visitors would eat deer. Therefore, the contaminated fraction of meat consumed was $0.02(5.1 \mathrm{~kg} / \mathrm{yr} \times 0.2 / 51.1 \mathrm{~kg} / \mathrm{yr}=0.02)$.

9. The precipitation and irrigation rates assumed were 123 and $26 \mathrm{~cm} / \mathrm{yr}$, respectively. Approximately $20 \%$ of the precipitation was lost by runoff and $46 \%$ of the remainder was lost by evapotranspiration, resulting in a net infiltration rate of $79 \mathrm{~cm} / \mathrm{yr}$ (ANL 1994).

10. The sandy soils in the decontaminated area have a density of $1.66 \mathrm{~g} / \mathrm{cm}^{3}$ (CDM 1991) and a total and effective porosity of 0.33 and 0.24 , respectively (Warren 1968). The hydraulic conductivity in the unsaturated zone was 5,000 $\mathrm{m} / \mathrm{yr}$. The hydraulic conductivity and hydraulic gradient in the saturated zone were $20,000 \mathrm{~m} / \mathrm{yr}$ and 0.0048 , respectively (CDM 1995a and Warren 1968). The " $b$ " parameter used by RESRAD to calculate the saturation ratio in the unsaturated zones was 4.9 (ANL 1993a).

11. Site-specific distribution coefficients used to calculate radionuclide leaching and transport in groundwater were measured at the HWMF for uranium and strontium (Fuhrmann 1995) and at the nearby baseball field for cesium and radium (Fuhrmann 1996). For other chemicals, generic distribution coefficients for sandy soils from the literature were used (Baes 1983 and Sheppard 1990).

12. After remedial action, the decontaminated area was not covered with clean fill but with excavated soil that was less than or equal to the DCGL.

13. All other parameters in Appendix A, columns 3 and 4, were set to RESRAD defaults, unless specified otherwise.

\subsubsection{Calculations and Results}

The RESRAD 5.61 pathway-analysis models were used to calculate radiation dose at 30-year increments from 2047 to 2317 (Appendix F). Since cesium-137 and strontium-90 decay to minimal levels after several half-lives, a period of 270 years (about nine half-lives for cesium-137 and about ten half-lives for strontium-90) was used. The NRC's and EPA's assessment period of $1,000 \mathrm{yrs}$ was not used because of these relatively short half-lives. The 
integrated dose to a single visitor over this 270 - year time-frame from initial radiological conditions was calculated (using the volume-weighted geometric and arithmetic average concentrations) to be 0.005 to $0.28 \mathrm{rem}$. Therefore, for the 30 visitors to this open space over this 270 years of future use, the collective dose associated with the projected radiological conditions was between 0.16 to 8.6 person-rem.

\subsubsection{Dose to Future Visitors to this Open Space after Remediation}

\subsubsection{Radiation Exposure Scenario}

This scenario was the same as that for Section 2.2.1.1 except that the levels of radioactive contaminants were remediated to the various risk-based remediation goals/limit, 1 $\mathrm{mrem} / \mathrm{yr}, 15 \mathrm{mrem} / \mathrm{yr}, 25 \mathrm{mrem} / \mathrm{yr}, 75 \mathrm{mrem} / \mathrm{yr}$, and the $100 \mathrm{mrem} / \mathrm{yr}$ public dose limit.

\subsubsection{Assumptions}

The same assumptions as described in section 2.2.1.2 were used

\subsubsection{Calculations and Results}

Although the residual radioactive material guidelines will be based on one of the above proposed remediation goals, past experience has proven that for most remediating, excluding the uranium-mill tailings, the actual radiation levels after remediation are typically lower than those associated with the final remediation goal. However, as an upper-bound limit for the future visitors to this open space, it was assumed that doses to visitors would depend on residual contamination levels dictated by the limits of the risk-based remediation goals/limit of $1 \mathrm{mrem} / \mathrm{yr}$, $15 \mathrm{mrem} / \mathrm{yr}, 25 \mathrm{mrem} / \mathrm{yr}, 75 \mathrm{mrem} / \mathrm{yr}$, or $100 \mathrm{mrem} / \mathrm{yr}$ for the 270 -year period. The 270 -year collective doses to future visitors who frequent the former HWMF site were estimated to be 0.001-0.004 person-rem at the $1 \mathrm{mrem} / \mathrm{yr}$ risk-based remediation goals/limit, 0.018-0.060 personrem at $15 \mathrm{mrem} / \mathrm{yr}, 0.030-0.100$ person-rem at $25 \mathrm{mrem} / \mathrm{yr}, 0.091-0.302$ person-rem at 75 $\mathrm{mrem} / \mathrm{yr}$, and 0.121-0.402 person-rem at the $100 \mathrm{mrem} / \mathrm{yr}$ limit (see Appendix F); Table 2.2-1 summarizes these values. 
Table 2.2-1 Collective Dose to the Future Visitors after Remediation

\begin{tabular}{|c|c|}
\hline \multirow{2}{*}{$\begin{array}{c}\text { Risk-based Remediation } \\
\text { Goals/Limit (mrem/yr) }\end{array}$} & $\begin{array}{c}\text { Volume-weighted Geometric and } \\
\text { Arithmetic Average Soil } \\
\text { Concentrations }\end{array}$ \\
\cline { 2 - 2 } & $\begin{array}{c}\text { Collective Dose: Visitors After } \\
\text { Remediation, } \\
\text { (person-rem) }\end{array}$ \\
\hline \hline 1 & $0.001-0.004$ \\
\hline 15 & $0.018-0.060$ \\
\hline 25 & $0.030-0.100$ \\
\hline 75 & $0.091-0.302$ \\
\hline 100 & $0.121-0.402$ \\
\hline
\end{tabular}

\subsubsection{Dose to the Public from Excavating, Packaging, and Storing the Soil On-site}

\subsubsection{Radiation Exposure Scenario}

The dust generated on site during remediation can be blown off-site and result in exposures to the nearby public. It was assumed that dust-suppression techniques and other contamination control procedures would be followed during remediation, and airborne monitoring for radionuclides would ensure that the radiation dose to workers and the public would be maintained within existing radiation limits, and as far below these limits as reasonably achievable. Nevertheless, it was appropriate to estimate these potential impacts to the public. This section evaluated the risks associated with the release of contaminated dust into air during remediation at the HWMF. This 12 acre site consisted of a contaminated area of 5 acres $\left(19,200 \mathrm{~m}^{2}\right)$ and approximately 8,000 to $78,000 \mathrm{yd}^{3}\left(6,100\right.$ to $\left.60,000 \mathrm{~m}^{3}\right)$ of soil which must be removed.

\subsubsection{Assumptions}

The release of contaminated dust from the site was estimated using empirical correlations given in EPA 1995 and 1985. These estimates are highly uncertain, both because the correlations themselves are very uncertain, and because the input parameters used are subjective choices and may not represent the actual conditions. These methods are order-of-magnitude estimates for estimating potential exposure. 


\subsubsection{Calculations and Results}

The following relationship, Equation (4), was used to estimate the dust produced during excavation and loading of the soil into packages (USEPA 1995). Excavation was assumed to be the major cause for suspending the dust.

$$
E_{10}=0.009 k \sum \frac{\frac{S U H}{(5)(2.2)(1.5)}}{\left(\frac{M}{2}\right)^{2} x\left(\frac{Y}{4.6}\right)^{0.33}}
$$

where,

$$
\begin{array}{ll}
\mathrm{E}_{10} & =\mathrm{kg} \text { dust released per } \mathrm{Mg} \text { of soil handled } \\
\mathrm{k} & =\text { particle-size multiplier }=0.36 \text { for particles }<10 \mathrm{um} \\
\mathrm{S} & =\text { silt content, } 29 \text { percent } \\
\mathrm{U} & =\text { mean wind speed, } 4 \mathrm{~m} / \mathrm{sec} \\
\mathrm{H} & =\text { drop height, } 2 \mathrm{~m} \\
\mathrm{M} & =\text { soil moisture content, } 40 \text { percent (with dust suppression) } \\
\mathrm{Y} & =\text { dumping device capacity, } 2 \mathrm{~m}^{3}
\end{array}
$$

Using these values and solving equation (3) gives $1.5 \times 10^{-2} \mathrm{~kg}$ of dust suspended per $\mathrm{Mg}$ of soil dumped. Assuming that a soil volume of $78,000 \mathrm{~m}^{3}$ will be loaded onto trucks at the $1 \mathrm{mrem} / \mathrm{yr}$ risk-based remediation goals/limit, $20,000 \mathrm{~m}^{3}$ of soil at $15 \mathrm{mrem} / \mathrm{yr}, 15,000 \mathrm{~m}^{3}$ of soil at $25 \mathrm{mrem} / \mathrm{yr}, 7,000 \mathrm{~m}^{3}$ of soil at $75 \mathrm{mrem} / \mathrm{yr}$ and $6,100 \mathrm{~m}^{3}$ of soil at $100 \mathrm{mrem} / \mathrm{yr}$, and that the bulk density of the soil was $1.66 \mathrm{~g} / \mathrm{cc}\left(1.66 \mathrm{Mg} / \mathrm{m}^{3}\right)$, then there would be $129,480,33,200$, $24,900,11,620$, and $10,126 \mathrm{Mg}$ of soil removed for each of the respective guidelines and limit. These values were multiplied by the factor of $1.50 \mathrm{E}-05$ to obtain the various values for the rate of dust emission $\mathrm{E}_{10}$, namely. 1,942 $\mathrm{g}$ of dust produced for the $1 \mathrm{mrem} / \mathrm{yr}$ risk-based remediation goals/limit, $498 \mathrm{~g}$ for $15 \mathrm{mrem} / \mathrm{yr}, 374 \mathrm{~g}$ for $25 \mathrm{mrem} / \mathrm{yr}, 174 \mathrm{~g}$ for $75 \mathrm{mrem} / \mathrm{yr}$, and $152 \mathrm{~g}$ for 100 $\mathrm{mrem} / \mathrm{yr}$ limit. The rate at which radioactive material will be released into the air, $Q_{i}$ is directly proportional to the concentration of radionuclide, $\mathrm{RSC}_{i}$, times the rate at which dust enters the air, $\mathrm{E}_{10}$ : 


$$
\mathrm{Q}_{\mathrm{i}} \quad=10^{-12} \mathrm{E}_{10} \mathrm{RSC}_{\mathrm{i}}
$$

where,

$$
\begin{aligned}
& \mathrm{Q}_{\mathrm{i}}=\text { release rate of radionuclide } \mathrm{I}, \mathrm{Ci} / \mathrm{yr} \\
& 10^{-12}=\mathrm{Ci} / \mathrm{pCi} \\
& \mathrm{E}_{10}=\text { rate of dust emission, } \mathrm{g} / \mathrm{yr} \\
& \mathrm{RSC}_{\mathrm{i}}=\text { concentration of radionuclide, } \mathrm{I} \text {, in soil, } \mathrm{pCi} / \mathrm{g}
\end{aligned}
$$

The resulting radioactive airborne releases were calculated using the spreadsheets given in Appendix F. These release rates were based on volume-weighted geometric and arithmetic average concentrations (see Appendix C for average concentrations). The results for the various risk-based remediation goals/limit are summarized in the Table 2.2-2 for cesium-137 and strontium-90:

Table 2.2-2 Fugitive-Dust Release Rates: Cesium-137 and Strontium-90

\begin{tabular}{|c|c|c|}
\hline $\begin{array}{c}\text { Risk-based } \\
\text { Remediation } \\
\text { Goals/Limit } \\
(\mathbf{m r e m} / \mathbf{y r})\end{array}$ & $\begin{array}{c}\text { Volume-Weighted Geometric and Arithmetic Average Soil } \\
\text { Concentrations }\end{array}$ \\
\cline { 2 - 3 } & $\begin{array}{c}\text { Cesium-137 Release Rate } \\
\text { (Ci/yr) }\end{array}$ & $\begin{array}{c}\text { Strontium-90 Release Rate } \\
\text { (Ci/yr) }\end{array}$ \\
\hline 1 & $5.17 \mathrm{E}-07-1.01 \mathrm{E}-05$ & $5.83 \mathrm{E}-09-2.91 \mathrm{E}-08$ \\
\hline 15 & $6.58 \mathrm{E}-07-7.75 \mathrm{E}-06$ & $6.97 \mathrm{E}-09-2.19 \mathrm{E}-08$ \\
\hline 25 & $7.40 \mathrm{E}-07-7.37 \mathrm{E}-06$ & $7.84 \mathrm{E}-09-2.05 \mathrm{E}-08$ \\
\hline 75 & $1.15 \mathrm{E}-06-7.57 \mathrm{E}-06$ & $1.24 \mathrm{E}-08-2.13 \mathrm{E}-08$ \\
\hline 100 & $1.22 \mathrm{E}-06-7.39 \mathrm{E}-06$ & $1.32 \mathrm{E}-08-2.07 \mathrm{E}-08$ \\
\hline
\end{tabular}


EPA's software application CAP88-PC Version 2.0 was used which was developed to demonstrate compliance with the national emission standards for hazardous substances (NESHAPS) (USEPA 1992). This computer code estimated the collective dose to the public from direct radiation, inhalation, and contaminated-plant-ingestion pathways. The pathway parameters used for the BNL site for demonstrating compliance with the Clean Air Act were used because they are reasonably representative values. The meteorology was that for the BNL site for 9 years, 1980-89. Population data were based on the 1990 census data for Suffolk and Nassau Counties. The collective dose estimates were based on an exposed population of 4,940,116 people within a 50-mile (80-kilometer) radius around the HWMF. The release rates were based on volume-weighted geometric and arithmetic average concentrations for the various risk-based remediation goals/limit and are summarized in the Table 2.2-2 for cesium-137 and strontium-90.

The computer printouts of the population distribution, input parameters, and estimated doses from the EPA's CAP-88 software application are documented in Appendix G. The population doses resulting from site remediation, expressed in terms of collective dose for the first year of exposure following the excavation are: $3.19 \mathrm{E}-05-6.20 \mathrm{E}-04$ person-rem for remediation to the $1 \mathrm{mrem} / \mathrm{yr}$ risk-based remediation goal, $3.98 \mathrm{E}-05-4.68 \mathrm{E}-04$ person-rem for to the $15 \mathrm{mrem} / \mathrm{yr}, 4.70 \mathrm{E}-05$ - $4.67 \mathrm{E}-04$ person-rem for the $25 \mathrm{mrem} / \mathrm{yr}, 6.96 \mathrm{E}-05-4.56 \mathrm{E}-04$ person-rem for the $75 \mathrm{mrem} / \mathrm{yr}$, and $7.51 \mathrm{E}-05$ - $4.54 \mathrm{E}-04$ person-rem for the $100 \mathrm{mrem} / \mathrm{yr}$ limit. Each subsequent year, the collective dose will decline due to radioactive decay and erosion. These data are summarized in the Table 2.2-3.

Table 2.2-3 Collective Dose ( first year only) to the Public from Remediation

\begin{tabular}{|c|c|}
\hline \multirow{2}{*}{$\begin{array}{c}\text { Risk-based Remediation Goals/Limit } \\
\text { (mrem/yr) }\end{array}$} & $\begin{array}{c}\text { Volume-Weighted Geometric and } \\
\text { Arithmetic Average Soil } \\
\text { Concentrations }\end{array}$ \\
\cline { 2 - 2 } & $\begin{array}{c}\text { Collective Dose: Public from } \\
\text { Remediation } \\
\text { (person-rem) }\end{array}$ \\
\hline \hline 1 & $3.19 \mathrm{E}-05-6.20 \mathrm{E}-04$ \\
\hline 15 & $3.98 \mathrm{E}-05-4.68 \mathrm{E}-04$ \\
\hline 25 & $4.70 \mathrm{E}-05-4.67 \mathrm{E}-04$ \\
\hline 75 & $6.96 \mathrm{E}-05-4.56 \mathrm{E}-04$ \\
\hline 100 & $7.51 \mathrm{E}-05-4.54 \mathrm{E}-04$ \\
\hline
\end{tabular}




\subsubsection{Dose to the Public from Transporting and Disposing of the Soil Off-Site}

\subsubsection{Radiation Exposure Scenario}

The public can be exposed to radiation from the transport and off-site disposal of contaminated soil. Maximum individual doses were calculated using the Microshield 5.01 computer code (Grove 1996). The collective dose was estimated for members of the public who tailgated the truck, those who were caught in traffic near the truck, truck drivers parked next to the waste truck while resting in their vehicle at truck stops, and public that were exposed during refueling of the truck.

Four scenarios, along with the assumptions described below, were used to estimate the dose during routine transport. These were (1) two people in one vehicle were assumed to be driving about 100 feet (30.48 meters) away from the back of the four B-25 waste containers; (2) two people were assumed to be caught in traffic and located 12 feet ( 3.6 meters) away from the side surface of the four B-25 waste containers; (3) two fellow truck-drivers were assumed to be resting at a truck-stop parking lot while the waste-shipment drivers were eating. The fellow truck drivers were located $12 \mathrm{ft}$. (3.6 meters) from the side surface of the four B-25 waste containers; and (4) one gas-station attendant and five members of the public were assumed to have received radiation during the refueling of the truck at an average distance of 75 feet (23 meters) from the back side of the four B-25 waste containers (Griego 1996).

The hypothetical radiological collective doses were calculated for the 2 years that were estimated to be needed to complete the waste shipments to Envirocare and Fluor Daniels Solid Waste Disposal Site.

As for radiation doses to members of the public from waste storage, it was assumed that if the soil was placed in a properly designed radioactive-waste TSD facility, it would be isolated indefinitely from direct contact with most individuals, and that the potential for groundwater contamination would essentially be eliminated. This assumption was made whether the soil was disposed of in above- or below-ground engineered facilities.

\subsubsection{Assumptions}

public:

The following general assumptions were applied to the dose assessments for the

1. The contaminated soil was transported in B-25 steel containers. An eighteenwheel tractor-trailer with a low-bed trailer was used for the Envirocare shipments. Sole-source vehicles were used for the Fluor Daniels Solid Waste Disposal Site shipments. For both, the maximum payload was 40,000 pounds. 
This equates to a maximum of four B-25 waste containers $(12 \mathrm{CY})$ per vehicle.

2. The dose rate from the four steel containers on the flat bed caused most of the radiation dose. Each B-25 container had 3/16-inch carbon steel walls which were assumed to be composed of $100 \%$ iron. The dimensions of each package was 4' x 4' x 6' $\left(96 \mathrm{ft}^{3}\right.$ or $\left.3 \mathrm{yd}^{3}\right)$ and held a maximum payload of 10,000 pounds. The Fluor Daniels Solid Waste Disposal Site B-25 waste containers were filled with $25 \%$ Portland Type I cement and $75 \%$ sand/gravel to stabilize the waste for shipment (stabilization is required by Hanford's waste acceptance criteria for cesium-137 concentrations greater than 2,800 $\mathrm{pCi} / \mathrm{g})$.

3. The radiation buildup resulting from the scatter was calculated for all the material between the source point and the dose point using the tabulated infinite medium buildup factor of the material selected i.e., the soil. The soil at BNL was assumed to be predominately sandy gravel or silicon dioxide $\left(82 \%\right.$ by weight $\left.\mathrm{SiO}_{2}\right)$ and moisture $\left(18 \% \mathrm{H}_{2} \mathrm{O}\right.$ ) (USGS 1975) with a bulk density of $1.66 \mathrm{~g} / \mathrm{cm}^{3}$ (CDM 1991). The concrete/waste mix was assumed to be $75 \%$ sand/gravel and $25 \%$ Portland Type I concrete (Norton 1997). The chemical composition was that of NBS concrete (Grove 1996) with a density of $2.35 \mathrm{~g} / \mathrm{cm}^{3}$ (shown in Appendix E).

4. The most appropriate irradiation geometry for the anthropomorphic phantom (see Figure 2.1-1) from Publication 51 of the International Commission on Radiological Protection was used to calculate the effective dose equivalent rate to the public for the various scenarios (see Appendix $\mathrm{H}$, Microshield printout for geometry used). No shielding was afforded by the walls of the car or structures between the B-25 and the passengers, fellow drivers, or gasstation attendants.

5. The radioactive material was uniformly distributed in the soil or concrete mix and the nuclide that contributed most significantly to the external radiation dose in the cab was cesium- 137.

6. The travel time from Upton, New York to Fluor Daniels Solid Waste Disposal Site, Washington was 44 hours (AutoMap 2.02 software - 2,806 miles at about $63 \mathrm{mph}$ ) and was 35 hours from Upton, New York to Clive, Utah (AutoMap 2.02 software - 2,245 miles at about $65 \mathrm{mph}$ ). The average truck speed included the time spent in traffic jams.

7. The number of trips was determined using the volumes in Appendix $\mathrm{C}$ and a vehicle payload of 12 CY for the trips to Envirocare and also to Fluor Daniels Solid Waste Disposal Site. The volumes of soil requiring disposal and the 
number of trips to Fluor Daniels Solid Waste Disposal Site and Envirocare are listed in Table 2.1-4.

The collective dose and associated risk to the public associated with off-normal shipments, i.e., accidents, was considered negligible. The following assumptions were applied to assessing the dose to the public from Scenario 1 - Tailgater: There were two passengers in the tailgating vehicles. The trip to Fluor Daniels Solid Waste Disposal Site in Richland, Washington had a car tailgating the waste-shipment vehicle at 100 feet for 8 hours out of the 44-hour journey (18\%). The trip to Envirocare in Clive, Utah, had a car tailgating at 100 feet for 5 hours out of the 35hour journey (14\%).

The following assumptions were applied for Scenario 2 - Traffic Jam: There were two passengers in the car that was caught in traffic next to the side of the waste-shipment vehicle; the shortest distance between them and the waste package was 12 feet. There were four traffic jams on the trip to Fluor Daniels Solid Waste Disposal Site, Washington, and four on the trip to Clive, Utah. The stop time for each traffic jam was 0.5 hours.

The following assumptions were applied to Scenario 3 - Drivers at Truck Stop: There were two drivers near the waste-shipment vehicle parked at the truck stop; the shortest distance between the waste package and these two drivers was 12 feet. There were four stops per day on the 2-day trip to Fluor Daniels Solid Waste Disposal Site, Washington, and also four stops per day on the 1.5 day trip to Clive, Utah. The time at each truck stop was 1.0 hour.

The following assumptions were applied to Scenario 4 - Refueling Stops: There was one gas-station attendant and five members of the public at the full-service gas station. The average distance between the back of the waste package and the people exposed was 75 feet (Griego 1996). The range of the fully loaded truck was 600 miles/tank (assume dual 75 -gallon fuel tanks and a mileage rating of $4 \mathrm{mpg}$ hauling a full payload). The trip to Fluor Daniels Solid Waste Disposal Site, Washington was 2,806 miles, and that to Clive, Utah was 2,245 miles. The time for each refueling was 0.33 hour (Griego 1996).

Because the soil was packaged, and because of properly engineered barriers at the TSD, it was assumed that the exposures to the public from off-site disposal would be minimal.

\subsubsection{Calculations and Results}

Radiological impacts to the public from transport were calculated using the Microshield 5.01 computer code. The software printouts are shown in Appendix E, together with the volume-weighted geometric and arithmetic average concentrations used for the Fluor Daniels Solid Waste Disposal Site shipments and Envirocare shipments. 
The collective dose impact to the public resulting from off-site transport and disposal was $0.32-6.68$ person-rem at $1 \mathrm{mrem} / \mathrm{yr}$ risk-based remediation goal; $0.31-6.54$ person-rem at $15 \mathrm{mrem} / \mathrm{yr} ; 0.31-6.50$ person-rem at $25 \mathrm{mrem} / \mathrm{yr}, 0.30-6.31$ person-rem at 75 $\mathrm{mrem} / \mathrm{yr}$, and $0.30-6.28$ person-rem at $100 \mathrm{mrem} / \mathrm{yr}$ dose limit. These data are summarized in Table 2.2-4.

Table 2.2-4 Collective Dose to the Public Resulting from Transport and OffSite Disposal

\begin{tabular}{|c|c|}
\hline \multirow{2}{*}{$\begin{array}{c}\text { Risk-based Remediation } \\
\text { Goals/Limit (mrem/yr) }\end{array}$} & $\begin{array}{c}\text { Volume-Weighted Geometric and } \\
\text { Arithmetic Average Soil } \\
\text { Concentrations }\end{array}$ \\
\cline { 2 - 2 } & $\begin{array}{c}\text { Collective Dose: } \\
\text { Public from Transport and Disposal } \\
\text { (person-rem) }\end{array}$ \\
\hline \hline 1 & $0.32-6.68$ \\
\hline 15 & $0.31-6.54$ \\
\hline 25 & $0.31-6.50$ \\
\hline 75 & $0.30-6.31$ \\
\hline 100 & $0.30-6.28$ \\
\hline
\end{tabular}

\subsubsection{Dose Averted or Expended to Members of the Public: Summary}

In summary, the results show that the potential radiation doses to the public resulting from excavation and disposal of the contaminated soil off-site were about a factor of two greater than the potential radiation dose that would be averted due to remediation. The dose assessment has shown that net collective doses averted of 1.87 person-rem would result from remediation to the $1 \mathrm{mrem} / \mathrm{yr}$ risk-based remediation goal; 1.95 person-rem to $15 \mathrm{mrem} / \mathrm{yr} ; 1.95$ person-rem to 25 $\mathrm{mrem} / \mathrm{yr} ; 1.93$ person-rem to $75 \mathrm{mrem} / \mathrm{yr}$; and 1.87 person-rem to the $100 \mathrm{mrem} / \mathrm{yr}$ dose limit. The collective dose would be averted to future members of the public if the excavation and offsite disposal remedial actions were completed in 1999. Therefore, the potential radiological impacts to the public associated with excavating, transporting and disposing of contaminated soil off-site were larger than the potential collective dose averted (net collective dose) by remediation. Table 2.2-5 summarizes the estimated saving, impacts, and the averted or expended (negative) collective doses from remediation of the HWMF. 
Table 2.2-5 Collective Dose Averted or Expended to Future Members of the Public: Summary

\begin{tabular}{|c|c|c|c|}
\hline $\begin{array}{c}\text { Risk-based } \\
\text { Remediation } \\
\text { Goals/Limit } \\
\text { (mrem/yr) }\end{array}$ & $\begin{array}{c}\text { Public Collective } \\
\text { Dose Savings } \\
\text { (person-rem) }\end{array}$ & $\begin{array}{c}\text { Public Collective } \\
\text { Dose Impacts } \\
\text { (person-rem) }\end{array}$ & $\begin{array}{c}\text { Net Collective } \\
\text { Dose to Public } \\
\text { (person-rem) }\end{array}$ \\
\hline \hline 1 & 8.55 & 6.68 & 1.87 \\
\hline 15 & 8.49 & 6.54 & 1.95 \\
\hline 25 & 8.45 & 6.50 & 1.95 \\
\hline 75 & 8.24 & 6.31 & 1.93 \\
\hline 100 & 8.15 & 6.28 & 1.87 \\
\hline
\end{tabular}

\subsection{Dose to Basement Resident: Failure of Active Controls}

Most radiation protection standards (DOE 5400.5, proposed 10CFR834, the 1997 revision to 10CFR20, and draft 40CFR196) permit the use restrictions as a means of protecting the public. Because there could be temporary losses of the planned institutional controls, these standards sometimes include an upper limit on the dose should these restrictions fail. This dose cap is not necessarily an acceptable dose for release but it ensures that consequences of the loss of restrictions will not cause an individual to exceed the radiation dose limit.

\subsubsection{Radiation Exposure Scenario}

After the closure of BNL, it was assumed that Federal control for building on the property of the old HWMF was violated. A resident was assumed to build a home in the center of the remediated site. During remediation (planned to begin in 1999), the soil from the HWMF was excavated. The soil above an established soil-burial cutoff level was removed and either treated and recycled, or disposed of. The radioactive material in this recycled soil was buried at the HWMF and was covered with 3 feet of clean fill. After fifty years, i.e., 2047, the government relinquishes ownership of the BNL site. Shortly thereafter, an inadvertent future intruder constructs a residential structure with a $28^{\prime} \times 38^{\prime}$ foundation at the HWMF site. Brookhaven Town Building codes require three feet of the basement foundation to extend above grade with a minimum 9-inch-thick concrete walls and 4-inch-thick floor. The soil that was removed for pouring the foundation was later used for topsoil on this one-half acre lot. The depth of the contaminated topsoil was 6 inches. A bedroom was built in the basement and was used by one of the residents (see Figure 2.3-1). The soil-burial cutoff level was established so that the effective dose equivalent rate to the maximum exposed individual would not exceed $75 \mathrm{mrem} / \mathrm{yr}$ following the failure of active controls. 


\subsubsection{Assumptions}

The assumptions made for calculating the soil concentrations that would be equivalent to $75 \mathrm{mrem} / \mathrm{yr}$ for the failure of active controls scenario were as follows:

1. The individual occupied the basement 10 hours per day for 350 days each year, i.e., $3,500 \mathrm{hrs} / \mathrm{yr}$. This individual occupied the above ground portion of the house for 880 $\mathrm{h} / \mathrm{yr}$, and spent $2,190 \mathrm{~h} / \mathrm{yr}$ outdoors on the contaminated property.

2. The dose to this occupant was approximated using three separate source terms: (1) the radioactive material in the 6" of topsoil (all pathways including direct radiation for 880 hours indoors and 2,190 hours outdoors using RESRAD 5.61), (2) the radioactive material in the soil which was buried under $3^{\prime}$ of clean fill/geotextile membrane (all pathways except ground radiation using RESRAD 5.61), and (3) the radioactive material under the basement floor and 2' up the sides of the basement walls (ground radiation only for 3,500 hours in basement using Microshield 4.21).

3. No protection was considered for the institutional controls, i.e., commercial/industrial zoning by Brookhaven Township or the engineered safety features, i.e., fence and geotextile membrane.

4. The resident was exposed to radiation from the following pathways: direct radiation from the ground, direct radiation penetrating the walls/floors in the basement, inhalation of dust, ingestion of soil, eating fruits and vegetables grown in the suburban garden (irrigated with groundwater), and ingestion of groundwater.

5. A correction factor was needed because the resident was only exposed to the direct radiation from the topsoil for 880 hours instead of the 4,380 hours that was used as the value of the RESRAD parameter for the resident's indoor occupancy. Since the resident was occupying the basement for 3,500 hours per year out of the total hours spent indoors, an adjustment factor of $0.508=(0.25+0.8(880 / 8760)) / 0.25+0.8(0.50)$ was applied. This factor was multiplied by the ground dose-rate at 50 years on $\mathrm{p} .23$ in the RESRAD printout in Attachment A $(0.25=2190 / 8760$ was the fraction of time spent outdoors, whereas 0.5 was the fraction of time spent indoors that was used by RESRAD). A protection or shielding factor of 0.8 was included for calculating the dose indoors. No correction factor was applied to the direct radiation dose-rate from ground for the contaminated soil that was buried under the 3 ' cover because the cover material effectively shielded the direct radiation emitted from the residual radioactive material in the buried soil. 
Figure 2.3-1 Failure of Active Controls Scenario: Resident in Basement (not to scale)

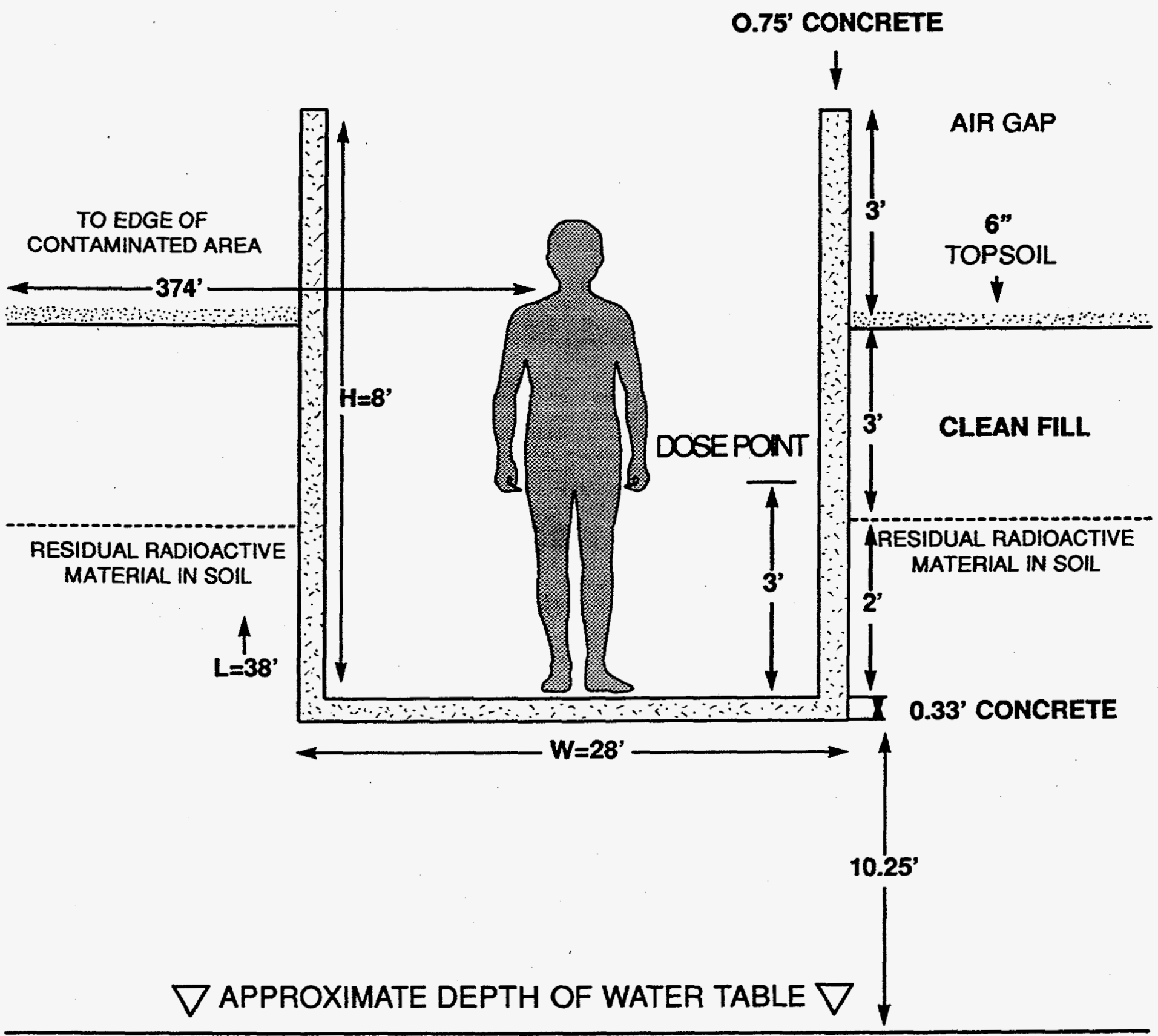


6. A 0.4 dilution factor was applied to the concentration of the buried dirt to obtain the concentrations in the topsoil. These buried concentrations were diluted since the soil that was excavated when constructing the foundation ( $\left.28^{\prime} \times 38^{\prime}\right)$, was made up of $3^{\prime}$ clean fill and 2' contaminated soil. Therefore, the topsoil was three-fifths clean-fill and two-fifths contaminated soil from recycling. RESRAD does not totally compensate for the displacement of source material occupied by the basement footprint nor for the shielding provided by the basement's walls and floor. These effects were assumed to be minimal and, when added, could cancel each other.

7. The dose at the center of the basement floor provided a reasonable estimate of the average dose rate for the direct radiation that penetrates it's walls/floors.

8. The radiation emanating from each wall was estimated using rectangular boxes of the same length as the wall. The depth of the boxes extended from three feet below grade to the top of the water table (approximately $16^{\prime}$ below ground level).

9. The radiation emanating from the floor was estimated using a rectangular box of the same area as the basement floor. The depth of the box extended from the bottom of the 0.33 -ft.-thick concrete floor to the top of the water table (approximately 16' below ground level).

10. The radioactive material was uniformly deposited in the soil; cesium-137 was the nuclide contributing the majority of the external radiation dose in the basement.

11. The point of the dose measurement, 3 feet above the floor, represented an individual laying on a bed and walking in the bedroom. The rotational geometry for the anthropomorphic phantom (see Figure 2.1-1) described in Publication 51 of the International Commission on Radiological Protection (ICRP 1987) was used to calculate the effective dose equivalent rate to this individual since it was the most representative geometry. No shielding was afforded by the bed or other furniture.

12. The radiation buildup resulting from the scatter was calculated for all the material between the source point and the dose point using the tabulated infinite medium buildup factor of the material selected, i.e., soil. The soil at BNL was assumed to be predominately sandy gravel or Silicon Dioxide ( $82 \%$ by weight $\mathrm{SiO}_{2}$ ) and moisture $\left(18 \% \mathrm{H}_{2} \mathrm{O}\right)$ (USGS 1975) with a bulk density of $1.66 \mathrm{~g} / \mathrm{cm} 3$ (CDM 1991). 


\subsubsection{Calculations and Results}

The RESRAD 5.61 software application developed by Argonne National Laboratory (ANL 1993) was used for the dose assessment for the slightly contaminated topsoil and the residual radioactive material under the three feet of clean cover. The software system calculated a site-specific radiation dose to an on-site resident (maximally exposed individual). A soil burial cutoff level is a radionuclide concentration or level of radioactivity that is acceptable if a site is to be used without radiological restrictions. This secondary derived concentration guideline limit is expressed as concentration of residual radionuclides in soil, or concentrations of radon decayproducts that can be safely allowed to remain in the ground. The soil burial cutoff level was based on the following criteria: (1) the annual radiation dose with the failure of all institutional controls and engineered safety features should not exceed $75 \mathrm{mrem} / \mathrm{yr}$, and (2) doses should be kept as low as reasonably achievable (ALARA). Six environmental pathways are considered in this residential scenario: direct exposure, inhalation, radon, ingestion of plant foods, ingestion of soil, and drinking groundwater. RESRAD uses a pathway analysis method in which the relation between radionuclide concentrations in soil and the dose to a member of a critical population group is expressed as a pathway sum, which is the sum of products of "pathway factors." Pathway factors correspond to segments connecting compartments in the environment between which radionuclides can be transported or radiation transmitted. The dimensions and input data for the RESRAD computer calculations associated with the top six inches of soil (source term \#1) and the residual radioactive material under the three feet of clean cover fill (source term \#2) are given in Appendix I, Attachments A and B, respectively.

Microshield Version 4.21(Grove 1995), the software application was used to access the radiation dose to the occupant of the basement. Microshield calculations involve attenuation and buildup of gamma radiation to support the dose assessments for radiation exposures. The basic method of calculation was point kernel integration. The code uses fully verified nuclide library and material data, and presents results with and without a buildup simultaneously. The rectangular volume geometry was used for the radiation emanating through the basement walls and floor. The dimensions and input data for the contaminated soil around and under the basement (source term \#3) are provided in Appendix I, Attachment C.

Topsoil: All pathways excluding direct radiation (source term \#1) - The dose-to-soil concentration ratios calculated by the RESRAD computer code for the topsoil and the values adjusted for occupancy in the basement area are documented in the RESRAD computer printout in Appendix I, Attachment A, and are summarized in Table 2.3-1. 
Table 2.3-1. Dose-to-Soil Concentration Ratios for the Top 6 Inches of Contaminated Soil at 50 Years - Excluding Direct Radiation

\begin{tabular}{|c|c|c|}
\hline \multirow{2}{*}{ Radionuclide } & \multicolumn{2}{|c|}{$\begin{array}{c}\text { 6" Topsoil Dose-to-Soil Concentration Ratio @ 50 yrs } \\
\text { (mrem/yr per pCi/gm) }\end{array}$} \\
\cline { 2 - 3 } & $\begin{array}{c}\text { Residential Scenario } \\
\text { (Adjusted for Basement } \\
\text { Occupancy) }\end{array}$ & $\begin{array}{c}\text { Residential Scenario } \\
\text { (Adjusted for 40\% Dilution } \\
\text { and Basement Occupancy) }\end{array}$ \\
\hline \hline Cesium-137 & 1.88 E-01 & 7.53 E-02 \\
\hline Strontium-90 & 7.99 E-08 & 3.20 E-08 \\
\hline
\end{tabular}

Soil Below 3' Cover: All pathways excluding direct radiation (source term \#2) - The dose-to-soil concentration ratios calculated by the RESRAD computer code for the soil that was buried below three feet of clean fill are documented in the RESRAD computer printout in Appendix I, Attachment B, and summarized in Table 2.3-2.

Table 2.3-2. Dose-to-Soil Concentration Ratio for Contaminated Soil Buried Under 3 Feet of Clean Fill at 50 Years - Excluding Direct Radiation

\begin{tabular}{|c|c|}
\hline Radionuclide & $\begin{array}{c}\text { Soil Below 3' Cover } \\
\text { Dose-to-Soil Concentration Ratio @ 50 yrs } \\
\text { (mrem/yr per pCi/gm) }\end{array}$ \\
\hline Cesium-137 & $1.11 \mathrm{E}-04$ \\
\hline Strontium-90 & $2.46 \mathrm{E}-01$ \\
\hline
\end{tabular}

Soil Around and Under Basement: Direct radiation only (source term \#3) - The dose-tosoil concentration ratios calculated by the Microshield computer code for the basement contaminated soil, around and under the basement, are documented in the Microshield printout in Appendix I, Attachment C. Summing the exposure rates from the walls and floor using a source term of $1 \mathrm{pCi} / \mathrm{g}$ for cesium-137 yields the direct radiation dose to soil concentration ratio listed in Table 2.3-3. 
Table 2.3-3. Dose-to-Soil Concentration Ratio for Soil Surrounding Basement Direct Radiation

\begin{tabular}{|c|c|c|c|}
\hline $\begin{array}{l}\text { Radionuclide } \\
\text { (half life) }\end{array}$ & $\begin{array}{c}\text { Hourly Effective } \\
\text { Dose Equivalent Rate } \\
\text { to Soil Concentration } \\
\text { Ratio } \\
\text { (mrem/hr per } \\
\text { pCi/gm) }\end{array}$ & $\begin{array}{c}\text { Annual Effective } \\
\text { Dose Equivalent Rate } \\
\text { to Soil Concentration } \\
\text { Ratio } \\
@ \text { t=0 } \\
\text { (mrem/yr per } \\
\text { pCi/gm) }\end{array}$ & $\begin{array}{c}\text { Annual Effective } \\
\text { Dose Equivalent } \\
\text { Rate to Soil } \\
\text { Concentration Ratio } \\
@ \mathrm{t}=\mathbf{5 0} \text { yrs } \\
\text { (mrem/yr per } \\
\text { pCi/gm) }\end{array}$ \\
\hline $\begin{array}{c}\text { Cesium-137 } \\
\left(\mathrm{T}_{1 / 2}=30.17 \mathrm{y}\right)\end{array}$ & 6.77 E-05 & 2.37 E-01 & 7.51 E-02 \\
\hline
\end{tabular}

Total Corrected Dose-to-Soil Concentration Ratio: The dose-to-soil concentration ratios for the failure of active controls scenario that are documented in Appendix I, Attachments $A, B$, and C were totaled in the spreadsheet in Attachment D to provide the dose to soil concentration ratios in Table 2.3-4.

Table 2.3-4. Dose-to-Soil Concentration Ratio for the Failure of Active Controls Scenario

\begin{tabular}{|c|c|}
\hline Radionuclide & $\begin{array}{c}\text { Total Corrected Dose-to-Soil Concentration Ratio@ } \mathbf{5 0} \text { yrs } \\
\text { (mrem/yr per pCi/gm) }\end{array}$ \\
\hline \hline Cesium-137 & $1.51 \mathrm{E}-01$ \\
\hline Strontium-90 & $2.46 \mathrm{E}-01$ \\
\hline
\end{tabular}

HWMF-Volume Weighted Concentrations for the Average Nuclide Mixture that is Equivalent to $75 \mathrm{mrem} / \mathrm{yr}$ : Using the dose-to-soil concentration ratio above, a concentration that yields $75 \mathrm{mrem} / \mathrm{yr}$ criteria was determined for cesium-137 and strontium-90. Using the volume-weighted arithmetic average concentrations over the 0 to $12 \mathrm{ft}$ depth interval (see Attachment $\mathrm{C}-$ cesium- $137=1.47 \times 10^{4} \mathrm{pCi} / \mathrm{g}$ and strontium-90 $=4.09 \times 10^{1} \mathrm{pCi} / \mathrm{g}$ ) and the single radionuclide soil burial cutoff level results in the concentrations in the buried soil documented on the spreadsheet in Appendix I, Attachment D, and in Table 2.3-5. 
Table 2.3-5. Concentration of Buried Soil (Average HWMF Mixture) Equivalent to $75 \mathrm{mrem} / \mathrm{yr}$

\begin{tabular}{|c|c|c|c|}
\hline Radionuclide & $\begin{array}{c}\text { Single-Radionuclide } \\
\text { Soil Burial Equivalent to } \\
\mathbf{7 5} \mathbf{~ m r e m / y r} \\
\text { @ 50 yrs. } \\
\text { (pCi/g) }\end{array}$ & $\begin{array}{c}\text { Percent Contribution } \\
\text { to the 75 mrem/yr } \\
\text { Dose Equivalent Rate } \\
\text { (based on volume weighted } \\
\text { arithmetic average } \\
\text { concentration from 0 to 12 } \\
\text { feet) }\end{array}$ & $\begin{array}{c}\text { Concentration of Soil } \\
\text { Buried at HWMF } \\
\text { Equivalent to 75 mrem/yr } \\
\text { @ 50 yr } \\
\text { (pCi/gm) }\end{array}$ \\
\hline \hline Cesium-137 & 500 & $97 \%$ & 495 \\
\hline Strontium-90 & 300 & $3 \%$ & 2 \\
\hline
\end{tabular}

\subsection{Dose to a Resident from Drinking Groundwater}

Assessing the potential radiological impacts on groundwater was an important part of the approach for obtaining derived concentration guideline levels for BNL. A detailed groundwater dose assessment was performed because of the importance of the sole-source aquifer underlying $\mathrm{BNL}$ as a future resource to Long Island residents. First, RESRAD was used as a screening tool to assess worst-case potential impacts, but it was too conservative for assessing the potential radiological risk from drinking groundwater off-site. Next, because the radionuclide-specific screening levels were exceeded, a site specific groundwater model was used, developed for the BNL site by CDM (a BNL subcontractor). Then, the projected off-site concentrations were compared with the EPA's $4 \mathrm{mrem} / \mathrm{yr}$ safe drinking water standard. On-site projected concentrations exceeded the standard but off-site concentrations did not. Finally, since the groundwater on-site showed a significant impact-potential, special soil-to-groundwater remediation guidelines were developed. These represent the concentrations in soil that are equivalent to EPA's $4 \mathrm{mrem} / \mathrm{yr}$ safe drinking water standard. These values were compared to the derived concentration guideline levels obtained using the $15 \mathrm{mrem} / \mathrm{yr}$ and all applicable pathways; the most conservative value should be selected as the final remediation guideline.

\subsubsection{Radiation Exposure Scenario: Soil-to-Water Screening Levels and Remediation Guidelines}

Although the future-use scenario for the HWMF was undeveloped recreational land (open-space) and no ingestion of water was assumed, in this screening level scenario a person was assumed to reside on the site and drink water pumped from an on-site well. A second scenario was used in which a person lived at the southern boundary of BNL property and drank water from a hypothetical well located there. The CDM groundwater model, developed specifically for the BNL site, was used for calculating the soil-to-groundwater remediation guidelines. 
The laboratory is currently equipped with a water-treatment plant and a potable water distribution system. A public-water distribution system would probably be used by a future resident because the Suffolk County Department of Health Services requires that new housing developments be connected to a municipal water supply. In addition, new dwellings within 150 feet of a water main are required to be connected to the municipal water supply. However, to be conservative and protective of the sole-source aquifer, a resident was assumed to drink water from an on-site well and the nearest possible off-site well.

\subsubsection{Assumptions: Soil-to-Water Screening Levels and Remediation Guidelines}

The following assumptions were used for the dose assessment for the on-site well and calculation of the soil to water screening levels.

1. The hydrogeological parameters and associated values used in the RESRAD model to estimate leaching in the vadose and migration in the saturated zone at an average site location were area of contaminated zone $=20,000 \mathrm{~m}^{2}$, thickness of contaminated zone $=2 \mathrm{~m}$, length parallel to aquifer flow $=250 \mathrm{~m}$, time since placement of material $=0$ years, depth of cover material $=0 \mathrm{~m}$, bulk density of contaminated zone 1.66 $\mathrm{g} / \mathrm{cm}^{3}$, contaminated zone erosion rate $=0.001 \mathrm{~m} / \mathrm{yr}$, total porosity $=0.33$, effective porosity $=0.24$, unsaturated zone hydraulic conductivity $=5,000 \mathrm{~m} / \mathrm{yr}$, evapotranspiration coefficient $=0.46$, precipitation $=123 \mathrm{~cm} / \mathrm{yr}$, irrigation rate $=0.26$ $\mathrm{m} / \mathrm{yr}$, saturated zone hydraulic conductivity $=20,000 \mathrm{~m} / \mathrm{yr}$, saturated zone hydraulic gradient $=0.001$, well pump intake depth $=18 \mathrm{~m}$ below water table, well pumping rate $=250 \mathrm{~m}^{3} / \mathrm{yr}$, and thickness of uncontaminated unsaturated zone (distance from bottom of contaminated soil to top of water table) $=8.6 \mathrm{~m}$. The values of the distribution coefficients and other parameters are shown in Appendix A, column 2.

2. The resident's well was located at the down-gradient edge of the HWMF contaminated area. The resident drank $2 \mathrm{~L}$ of water per day for 350 days per year for 30 years. The fraction of household water contaminated was 1.0; the household fractional usage from groundwater was 1.0 , and the water storage time was 1 day. Water ingestion was the only pathway that was activated in the RESRAD software.

RESRAD 5.61 contains a simple, one-dimensional groundwater model that calculates the concentrations of radionuclides in ground water directly below the contaminated site. It does not estimate concentrations in an off-site potable well. The model assumes no dispersivity, and the receptor well was assumed to be located at the down-gradient edge of the contaminated zone. RESRAD does not solve the equations for solute transport in groundwater, but uses steady state or constant-flow fields. 
As discussed previously, the groundwater model in RESRAD should be considered as a screening tool. Therefore, since water ingestion at the HWMF was found to have a significant impact (estimates indicated that MCLs may be exceeded), a more sophisticated model was used to estimate groundwater concentrations.

The following assumptions were used for the dose assessment for the off-site well and the calculation of the soil-to-water remediation guidelines:

1. The hydrogeological parameters and the associated values that were used in CDM's proprietary particle track/contaminant transport groundwater model to simulate migration in the Upper Glacial and Magothy regions of the aquifer down-gradient of the HWMF site were time since placement of material $=49$ years $(1947-95)$ and 100 years $(1997-2097)$, effective porosity $=0.24$, hydraulic conductivity $=175(\mathrm{ft} / \mathrm{d})$, hydraulic gradient $=0.0048$, strontium-90 half life $=29$ years, strontium-90 retardation factor $=20$ (personnel communication with $\mathrm{H}$. Moe, CDM Boston, Massachusetts, January 23, 1997), and the measured value of the distribution coefficients at the HWMF for strontium-90 $=3.0 \mathrm{~cm}^{3} / \mathrm{g}$ (Fuhrmann 1996).

2. The simulation periods were 1947-95 and 1997-2097. In the second simulation, CDM assumed that the Operable Unit (OU) I pump-and-treat station at the southern boundary of OU I begins operating in 1997 and ends in 2011, pumping at a rate of 700 gpm (CDM 1996b). Other assumptions used in the particle-track simulation were continuous source, average flow-fields, and no intervening aquitards.

\subsubsection{Calculations and Results: Soil-to-Water Screening Levels and Comparison to Measured Soil and Groundwater Concentrations}

Soil-to-water screening levels were developed by running RESRAD for a suburban resident with only the groundwater-ingestion pathway active (see Appendix A, column 2, for RESRAD parameters). The concentrations in groundwater obtained from the RESRAD concentration report were used to obtain the groundwater concentrations listed in Tables 2.4-1 and 2.4-2. Ten-year intervals were specified for the times as initial RESRAD parameters. These calculations are based on the generic site parameters for a suburban resident summarized in the report, Deriving Soil Cleanup Guidelines for Radionuclides at Brookhaven National Laboratory (Meinhold 1997).

Table 2.4-1 lists the worst-case groundwater concentrations predicted beneath the waste site for a unit radionuclide concentration of $1 \mathrm{pCi} / \mathrm{g}$ in soil. The maximum concentrations for different radionuclides are projected to occur at the times specified in Table 2.4-1. These concentrations represent the estimated upper limit or maximum of the values that could be reached over 1,000 years. Table 2.4-1 also gives the conversion factors for water-ingestion dose 
for calculating the dose associated with each radionuclide, using measured/calculated drinking or groundwater concentrations. Table 2.4-1 shows that for strontium-90, the main radionuclide of concern for drinking water at the HWMF, the time to reach the maximum concentration is about 70 years, and assuming a $2 \mathrm{~L}$ per day intake, a resident would receive $0.5 \mathrm{mrem} / \mathrm{yr}$ per $\mathrm{pCi} / \mathrm{L}$; the EPA MCL is $8 \mathrm{pCi} / \mathrm{L}$.

Table 2.4-2 gives the soil-to-water concentration ratios versus time for the radionuclides at BNL that can leach into groundwater from soil over 1,000 years (Sr-90, Ra-226, U-234, U235, U-238). Figure 2.4-1 shows how the ratio (and associated doses) varies over time for these isotopes. Measured strontium-90 concentrations at groundwater monitoring well MW-88-04 from 1971 to 1995 are shown in Figure 2.4-2; these data were taken from the Site Environmental Monitoring Reports (BNL 1971-1995). The maximum concentration occurred in 1971 and was decreasing steadily until 1985 when an increase occurred. This graph shows the shorter time to reach the maximum concentration than estimated for the average contaminated site ( 15 versus 70 years). The HWMF depth of contaminated zone is $3.6 \mathrm{~m}$ and extends to the top of the water table: the average site parameters used for the soil-to-water screening levels were a contaminated zone of $2 \mathrm{~m}$ overlying an uncontaminated zone of $8.6 \mathrm{~m}$, i.e., depth to water was $10.6 \mathrm{~m}$.

Table 2.4-1 also gives the EPA MCLs, for comparison with measured or predicted groundwater concentrations. Historically, the strontium- 90 groundwater concentrations at the monitoring wells at the HWMF have been above the EPA MCL of $8 \mathrm{pCi} / \mathrm{L}$. The maximum concentrations occurred at MW 88-09, which is near the open detonation area. The highest concentration measured in groundwater during CDM's 1994/1995 remedial investigation was 150 $\mathrm{pCi} / \mathrm{L}$ at $\mathrm{MW} 88-10$ which lies in the paved-spill-area site.

The last column in Table 2.4-1 shows RESRAD-generated soil-to-water screening levels. The strontium-90 soil concentration equivalent to EPA's $1991 \mathrm{MCL}$ of $8 \mathrm{pCi} / \mathrm{L}$ was $1.2 \mathrm{pCi} / \mathrm{g}$. The maximum concentration measured during the 1994/1995 remedial investigation was 1,300 $\mathrm{pCi} / \mathrm{g}$ at location B 37 in the center of the HWMF. The strontium-90 soil-to-water screening level was exceeded in most soil samples collected during the OU I remedial investigation. The volume-weighted geometric average strontium-90 concentration was $6.7 \mathrm{pCi} / \mathrm{g}$ and the volumeweighted arithmetic average was $41 \mathrm{pCi} / \mathrm{g}$. By comparison, the derived concentration guideline level equivalent to $15 \mathrm{mrem} / \mathrm{yr}$ for the open-space scenario at 50 years, was $5,784 \mathrm{pCi} / \mathrm{g}$. Since the soil measurements conducted during the 1991 OU I remedial investigation showed strontium 90 concentrations that exceeded the soil-to- water screening level of $1.2 \mathrm{pCi} / \mathrm{g}$, a site-specific soilto- water remediation guideline must be derived. 
Figure 2.4-1 Dose (mrem/yr) and Concentration (pCi/l) vs. Time Associated with $1 \mathrm{pCi} / \mathrm{g}$ of Sr-90, U-234, U-235, and U-238
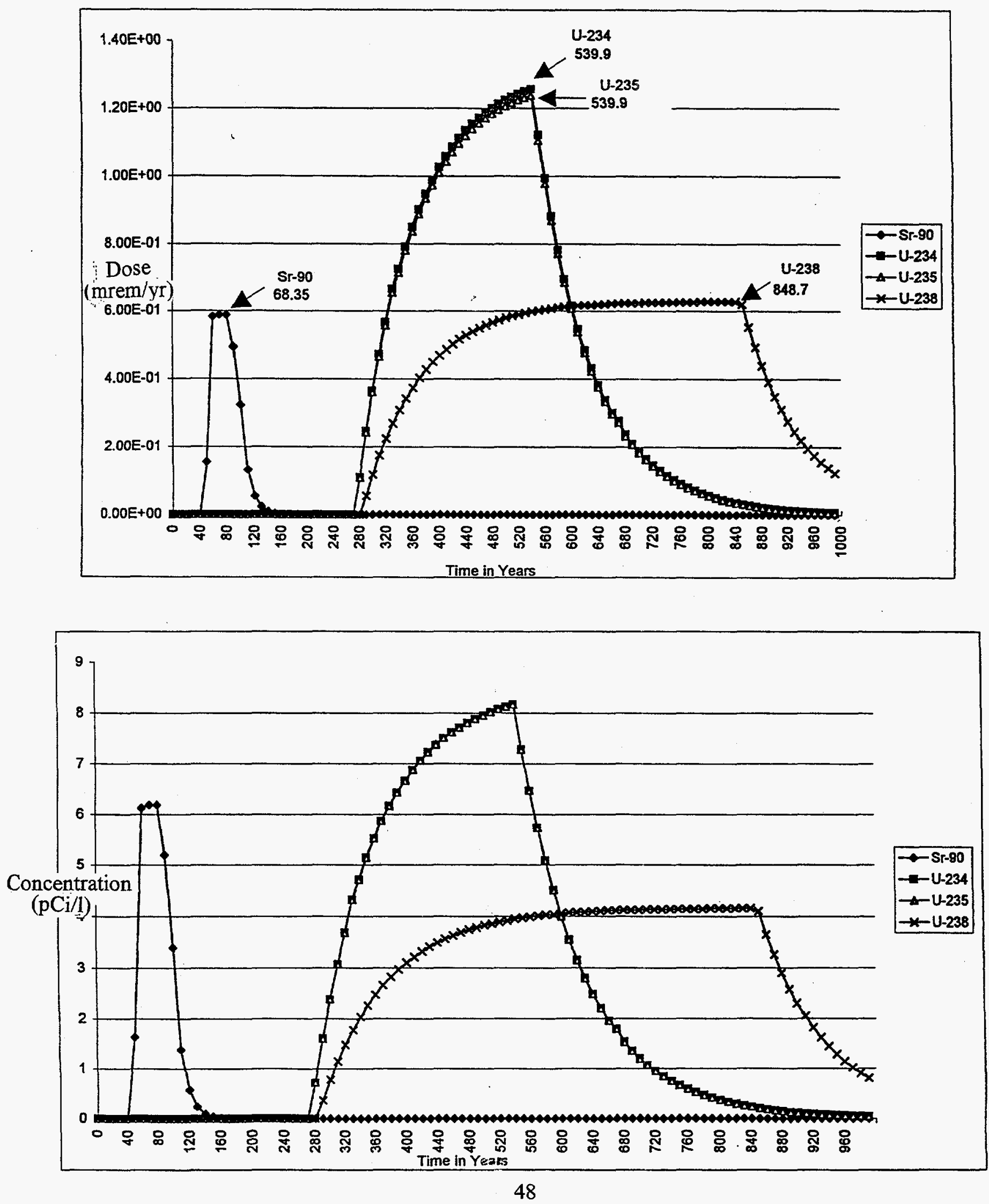
Figure 2.4-2 Hazardous Waste Management Facility: Monitoring Well 88-04 Sr-90 Concentrations

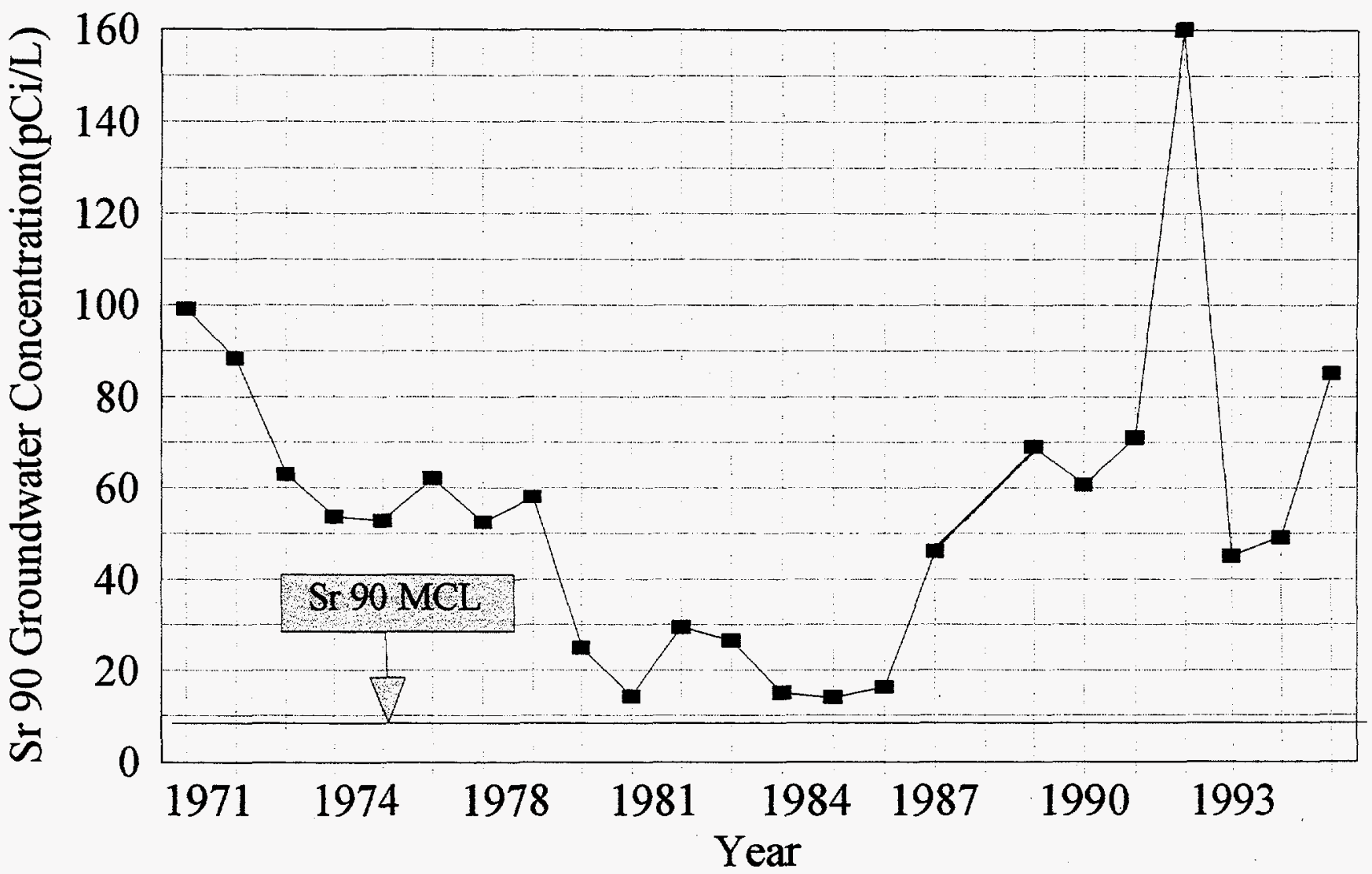




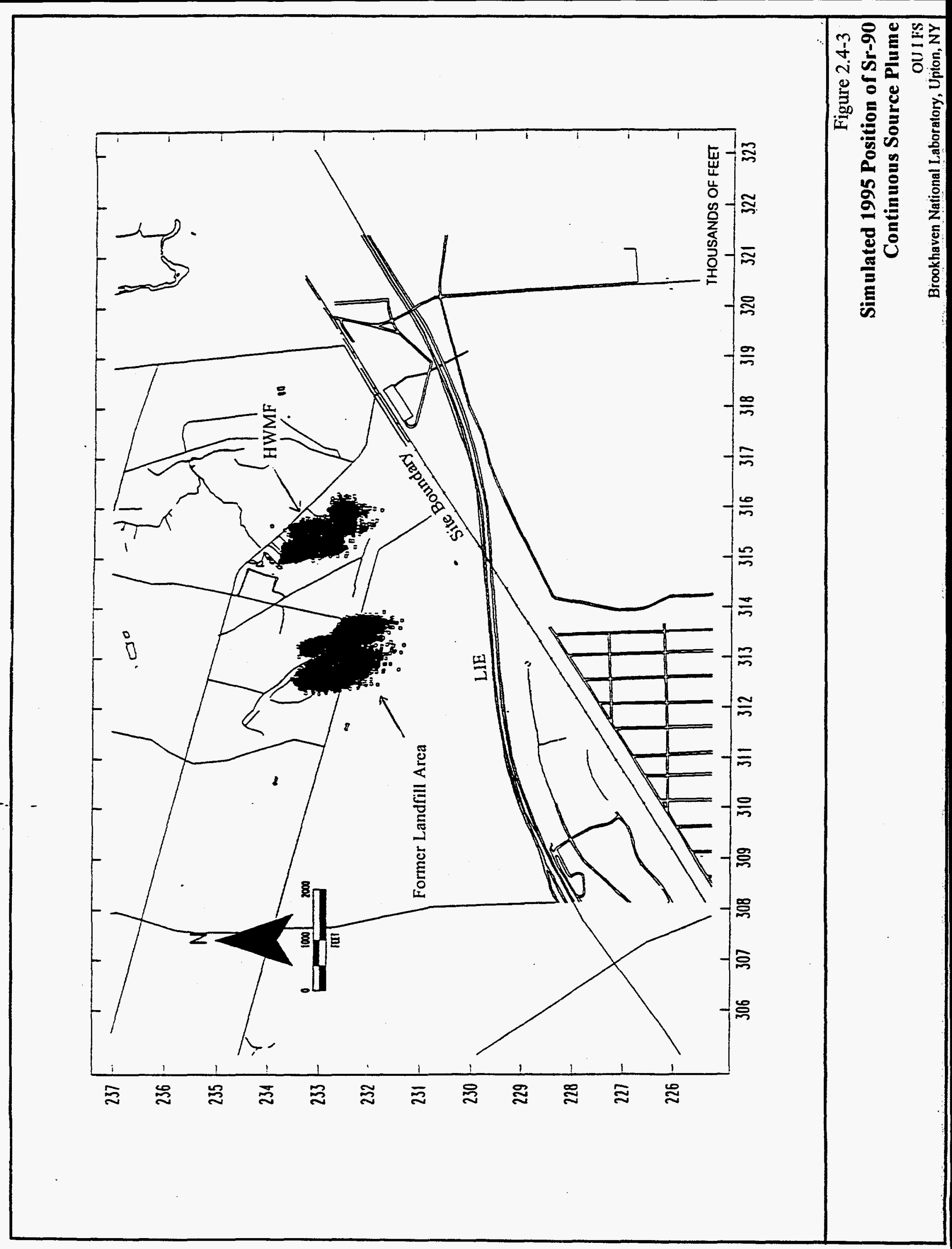




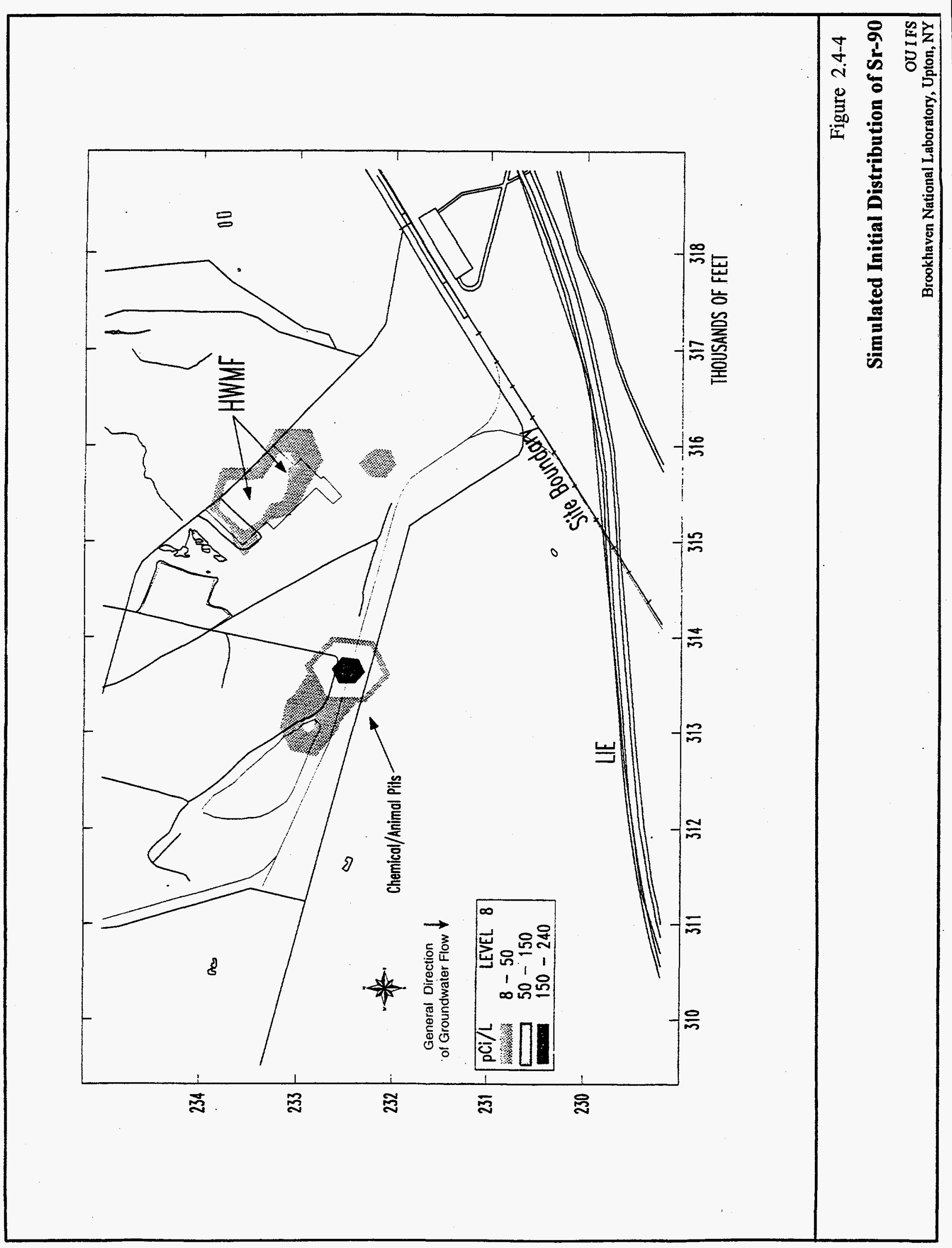




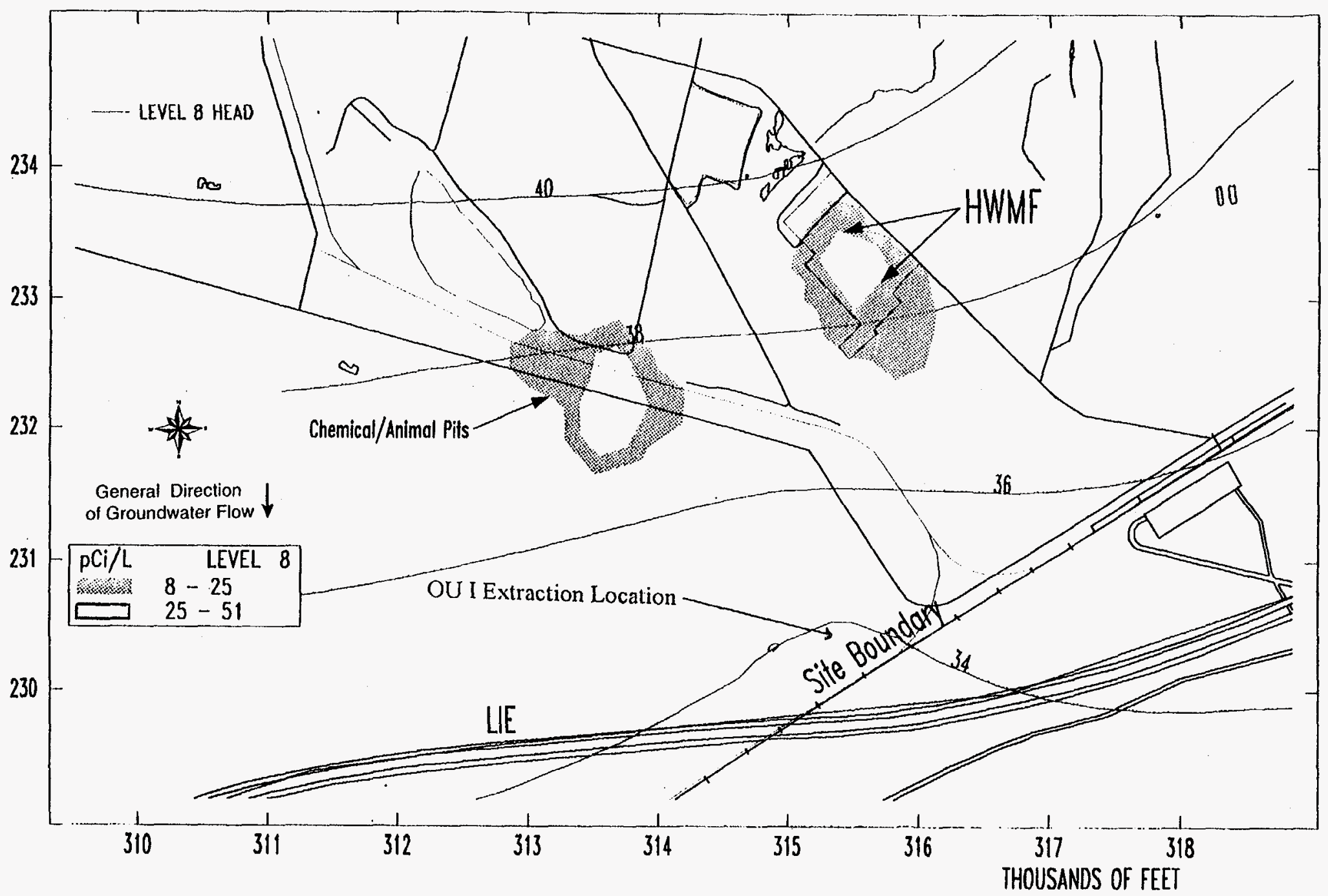

Figure 2.4-5

Simulated Distribution of Sr-90 After 14 Years of Pumping at OU I Boundary 


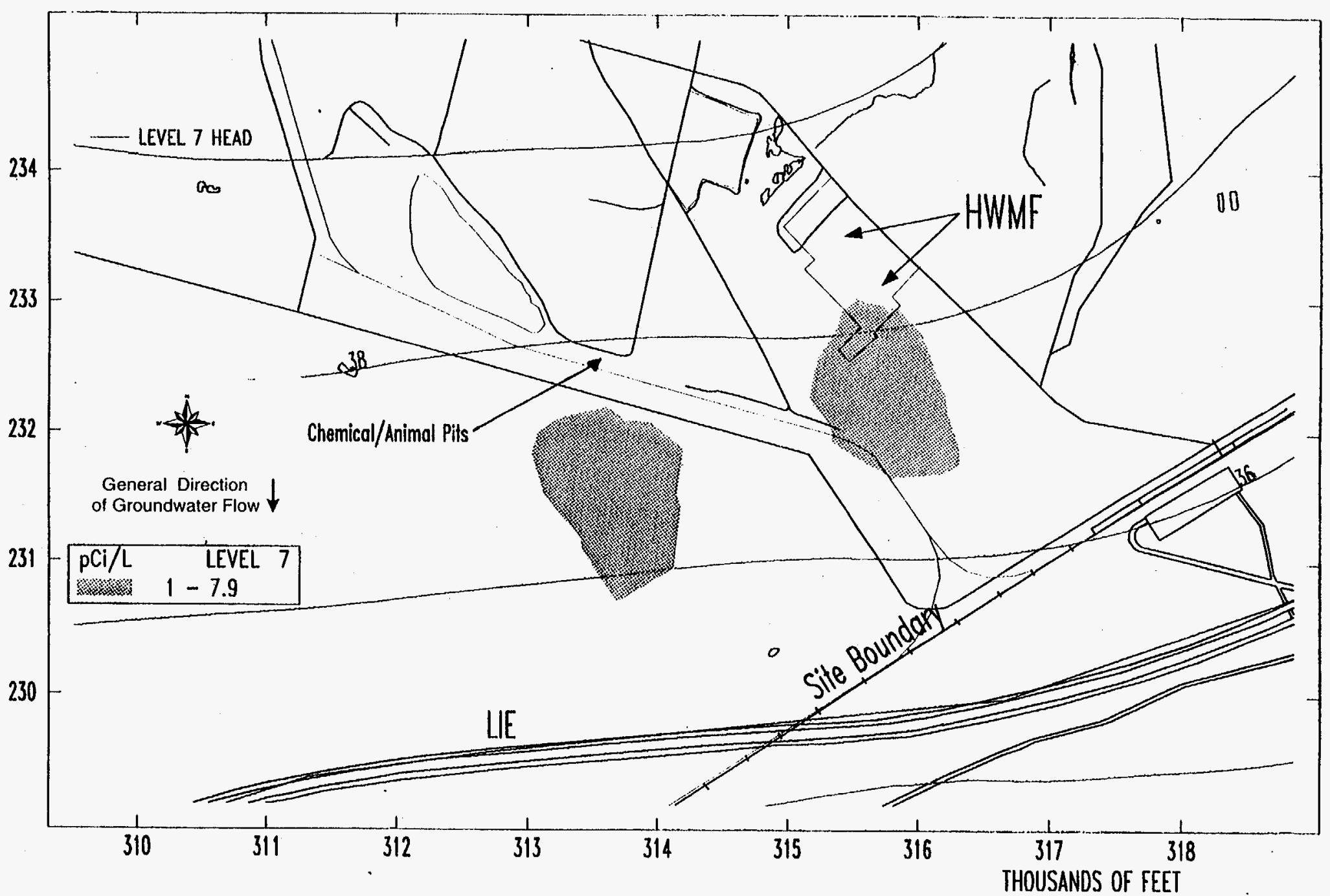

Figure 2.4-6

Simulated Distribution of Sr-90 in Year 2065 
The uranium-235 soil-to-water screening level was $32 \mathrm{pCi} / \mathrm{g}$ (uranium-235 MCL is 265 $\mathrm{pCi} / \mathrm{L}$ ). The maximum concentration measured during the 1994/1995 remedial investigation was $0.28 \mathrm{pCi} / \mathrm{g}$ at location B 36 in the center of the HWMF. Therefore, uranium-235 is not expected to impact drinking water, and only strontium- 90 will require a more refined assessment.

\subsubsection{Calculations and Results: Soil-to-Water Remediation Guidelines}

Next, a more detailed groundwater modeling analysis was performed to estimate off-site groundwater concentrations for comparison to MCLs. The proprietary particle track/contaminant transport model was used to calculate the down-gradient groundwater concentrations and to estimate plume transport. The proposed NYS Technical and Administrative Guidance Memorandum 4046 entitled "Determination of Soil Cleanup Objectives and Cleanup Levels," April 1995, was used to calculate the soil-to-water remediation guideline (NYS 1995). This guideline uses a simplified partition-theory model to determine soil standards for protecting water quality for organic contaminants.

Groundwater modeling was performed by CDM Federal Programs, New York, New York, to simulate future migration of the current strontium- 90 groundwater concentrations. This model, which was developed for BNL's Operable Unit I, is more fully described in Operable Unit I Engineering Evaluation and Cost Assessment Report (CDM 1995b ) and the OU I Design Report (CDM 1996a).

Figure 2.4-3 shows the simulated extent of retarded, continuous source plumes from the HWMF from 1947 to 1995 (CDM 1996b). The CDM geohydrologist estimated that strontium90 has not moved far in the groundwater since 1947. The migration rate in the Upper Glacial aquifer is less than $14 \mathrm{ft} / \mathrm{yr}$. Figure 2.4-4 shows the initial distribution of strontium-90 used for the simulation. These data are based on groundwater measurements from samples collected during the 1994/1995 remedial investigation. The groundwater concentrations selected were above the EPA $8 \mathrm{pCi} / \mathrm{L} \mathrm{MCL}$ and were input as slugs in the simulation model. Figure 4.2-5 shows the simulated distribution of strontium- 90 after 14 years of pumping, indicating that the plumes emanating from the HWMF will not be entrained by the drawdown from the OU I pumpand-treat remediation project. Figure 2.4-6 shows the simulated distribution of strontium-90 in the year 2065 which indicates that in 70 years the plume that is at or below the $8 \mathrm{pCi} / \mathrm{L}$ MCL will have migrated to just south of the firebreak road. CDM Federal Programs concluded that "The modeling predicts that the current levels of $\mathrm{Sr} 90$ in groundwater will have decreased to meet drinking water standards within 70 years. Therefore, there is an estimated period of up to 20 years after the site is released for public use when the failure of well installation restrictions could result in public exposure to radiologically contaminated drinking water" (CDM 1996b).

Soil-to-water remediation guidelines were determined by CDM Federal Programs. This model is consistent with the EPA's Soil Screening Guidance: Technical Background Document and Soil Screening Guidance: Users Guide (USEPA 1996). 
The CDM Federal Programs' geohydrologist calculated a soil-to-groundwater remediation guideline using the following equation (NYS, 1995):

$$
\mathrm{SWCG}=\mathrm{C}_{\mathrm{w}} \times \mathrm{DAF}_{\mathrm{N}} \mathrm{K}_{\mathrm{d}} \times 10^{-3}
$$

where,

$$
\begin{array}{ll}
\text { SWCG } & =\text { Soil-to-Water Cleanup Guideline (pCi/g) } \\
\mathrm{C}_{\mathrm{w}} & =\text { Maximum Contaminant Level, } \mathrm{Sr} 90=8 \mathrm{pCi} / \mathrm{L} \\
\mathrm{DAF} & =\text { Correction Factor, } 100 \text { (NYS 1995) } \\
\mathrm{K}_{\mathrm{d}} & =\text { Distribution Coefficient, } \mathrm{Sr}=3 \mathrm{~cm}^{3} / \mathrm{g} \text { (Fuhrmann 1996) } \\
10^{-3} & =\text { Conversion Factor for } \mathrm{L} / \mathrm{cm}^{3}
\end{array}
$$

Inputting the parameters and solving the equation for the SWCG yields $2.4 \mathrm{pCi} / \mathrm{g}$.

Next, CDM's geohydrologist scaled this guideline based on the following rationale “...groundwater modeling estimates indicate that recently observed Sr-90 concentrations as high as $150 \mathrm{pCi} / \mathrm{L}$ within the HWMF will attenuate to below the DWS before reaching the site boundary and will not migrate off-site at concentrations in excess of the DWS of $8 \mathrm{pCi} / \mathrm{L}$. By inference, the calculated SWCG for strontium- 90 can be greater than $2.4 \mathrm{pCi} / \mathrm{g}$ value calculated using NYS TAGM method with a $\mathrm{Cw}$ of $8 \mathrm{pCi} / \mathrm{L}$. Substituting $\mathrm{Cw}=150 \mathrm{pCi} / \mathrm{L}$ yields a $S W C G$ of $45 \mathrm{pCi} / \mathrm{g}$." CDM Federal Programs in the OU I Draft Feasibility Study Report Operable Unit I/Site-Wide Radiological Soils (CDM 1996b) concluded that "An alternate remediation goal of 45 $\mathrm{pCi} / \mathrm{g}$ for Sr 90 was calculated using the TAGM methodology, but was based on the maximum groundwater concentration measured during the 1994 to 1995 OU I remedial investigation program." This statement implies that the residual strontium- 90 concentrations of $45 \mathrm{pCi} / \mathrm{g}$ or less could remain in the HWMF soils without worsening groundwater concentrations.

As discussed previously, the maximum strontium- 90 concentration measured at the HWMF during the 1994/1995 remedial investigation was $1,300 \mathrm{pCi} / \mathrm{g}$ at location $\mathrm{B} 37$ in the center of the site. The strontium- 90 soil-to-water remediation guideline of $45 \mathrm{pCi} / \mathrm{g}$ was exceeded by concentration measurements on soil samples collected during this investigation.

In summary, the current and projected concentrations of strontium-90 in groundwater at a hypothetical well located at the HWMF site exceeded the EPA's Primary Drinking Water Regulation. A detailed projection of groundwater concentrations to a hypothetical off-site resident was made by CDM Federal Programs using a site-specific, particle track/contaminant transport groundwater model, which demonstrated that the strontium 90 concentrations would not exceed the EPA's Primary Drinking Water Regulations. 
Table 2.4-1 Peak Concentrations in Water Beneath Remediation Site per Unit Activity Concentration in Soil (Time of Maximum Groundwater Concentration in Years); Water Ingestion Dose-Conversion Factors; USEPA's MCLs, and Soil-to-Groundwater Screening Levels

\begin{tabular}{|c|c|c|c|c|c|}
\hline Radionuclide & $\begin{array}{c}\text { Maximum } \\
\text { Water:Soil } \\
\text { Ratio }^{\mathbf{1}} \text { (pCi/L } \\
\text { per pCi/g) }\end{array}$ & $\begin{array}{c}\text { Time of } \\
\text { Maximum } \\
\text { Groundwater } \\
\text { Concentration } \\
\text { (yr) }\end{array}$ & $\begin{array}{c}\text { Water Dose } \\
\text { Conversion } \\
\text { Factor }^{2} \\
(\mathrm{mrem} / \mathrm{yr} \text { per } \\
\text { pCi/L) }\end{array}$ & $\begin{array}{c}\text { USEPA } \\
\text { Proposed } \\
\text { MCL }^{3} \\
\text { (USEPA } \\
1991)(\text { pCi } / L)\end{array}$ & $\begin{array}{c}\text { Soil-to- } \\
\text { Groundwater } \\
\text { Screening } \\
\text { Level } \\
\text { Equivalent to } \\
\text { EPA's 1991 } \\
\text { MCL (pCi/g) }\end{array}$ \\
\hline Americium-241 & 0 & 210 & $6.20 \times 10^{-1}$ & 6.45 & $\mathrm{NC}$ \\
\hline Cesium-137 & 0 & - & $3.36 \times 10^{-3}$ & 119 & $\mathrm{NC}$ \\
\hline Cobalt-60 & 0 & - & $1.83 \times 10^{-2}$ & 218 & $\mathrm{NC}$ \\
\hline Europium-152 & 0 & - & $4.76 \times 10^{-3}$ & 841 & $\mathrm{NC}$ \\
\hline Europium-154 & 0 & - & $7.00 \times 10^{-3}$ & 573 & NC \\
\hline Europium-155 & 0 & - & $1.11 \times 10^{-3}$ & 3590 & $\mathrm{NC}$ \\
\hline Plutonium-238 & 0 & 560 & $6.15 \times 10^{-2}$ & 65 & $\mathrm{NC}$ \\
\hline Plutonium-239 & 0 & 725 & $6.15 \times 10^{-2}$ & 65 & $\mathrm{NC}$ \\
\hline Plutonium-240 & 0 & 700 & $6.15 \times 10^{-2}$ & 65 & $\mathrm{NC}$ \\
\hline Radium-226 & $1.4 \times 10^{-4}$ & $1000^{4}$ & - & 20 & 143,000 \\
\hline Strontium-90 & 6.8 & 70 & $5.00 \times 10^{-1}$ & 8 & 1.2 \\
\hline Uranium-234 & 8.2 & 540 & $1.54 \times 10^{-2}$ & 259 & 31 \\
\hline Uranium-235 & 8.2 & 540 & $1.54 \times 10^{-2}$ & 265 & 32 \\
\hline Uranium-238 & 4.0 & 850 & $1.53 \times 10^{-2}$ & 262 & 64 \\
\hline
\end{tabular}

1 Maximum concentration calculated by RESRAD code at the boundary of the contaminated site.

2 Values for MCLs taken from the Tables in 40 CFR 141-Proposed National Primary Drinking Water Regulations(assumes $4 \mathrm{mrem} / \mathrm{yr}$ ) (USEPA 1991).

3 Concentrations associated with $4 \mathrm{mrem} / \mathrm{yr}$ calculated using ICRP 30 parameters given in 40 CFR 141-Proposed National Primary Drinking Water Regulations (USEPA 1991). Current National Interim Primary Drinking Water Regulations (see EPA-570/9-76-003) specify MCL for gross beta-gamma emitters as $4 \mathrm{mrem} / \mathrm{y}$, and $\mathrm{Ra} 226 \& 228$ as $5 \mathrm{pCi} / \mathrm{L}$.

4 Radium concentrations are minimal $\left(1.4 \times 10^{-4} \mathrm{pCi} / \mathrm{l}\right)$. Maximum concentration occurs after 1,000 years.

NC -- Not calculated. Radionuclide concentrations in groundwater are minimal. 
Table 2.4-2 Worst-case Concentrations of Sr-90, Ra-226, U-234, U-235, and U-238 per Unit Soil Activity Concentration over 1,000 Years

\begin{tabular}{|c|c|c|c|c|c|}
\hline \multirow{2}{*}{$\begin{array}{l}\text { Time } \\
\text { (years) }\end{array}$} & \multicolumn{5}{|c|}{ Concentration (pCi/L per pCi/g) } \\
\hline & Sr-90 & $\mathrm{U}-234$ & U-235 & $\mathrm{U}-238$ & Ra-226 \\
\hline 0 & $0.00 E+00$ & $0.00 \mathrm{E}+00$ & $0.00 \mathrm{E}+00$ & $0.00 \mathrm{E}+00$ & $0.00 \mathrm{E}+00$ \\
\hline 10 & $0.00 \mathrm{E}+00$ & $0.00 \mathrm{E}+00$ & $0.00 \mathrm{E}+00$ & $0.00 \mathrm{E}+00$ & $0.00 \mathrm{E}+00$ \\
\hline 20 & $0.00 E+00$ & $0.00 E+00$ & $0.00 E+00$ & $0.00 \mathrm{E}+00$ & $0.00 E+00$ \\
\hline 30 & $0.00 \mathrm{E}+00$ & $0.00 \mathrm{E}+00$ & $0.00 \mathrm{E}+00$ & $0.00 \mathrm{E}+00$ & $0.00 \mathrm{E}+00$ \\
\hline 40 & $0.00 \mathrm{E}+00$ & $0.00 \mathrm{E}+00$ & $0.00 \mathrm{E}+00$ & $0.00 \mathrm{E}+00$ & $0.00 \mathrm{E}+00$ \\
\hline 50 & $1.63 E+00$ & $0.00 \mathrm{E}+00$ & $0.00 \mathrm{E}+00$ & $0.00 \mathrm{E}+00$ & $0.00 \mathrm{E}+00$ \\
\hline 60 & $6.12 E+00$ & $0.00 \mathrm{E}+00$ & $0.00 \mathrm{E}+00$ & $0.00 E+00$ & $0.00 \mathrm{E}+00$ \\
\hline 70 & $6.18 E+00$ & $0.00 \mathrm{E}+00$ & $0.00 \mathrm{E}+00$ & $0.00 \mathrm{E}+00$ & $0.00 \mathrm{E}+00$ \\
\hline 80 & $6.18 \mathrm{E}+00$ & $0.00 \mathrm{E}+00$ & $0.00 \mathrm{E}+00$ & $0.00 \mathrm{E}+00$ & $0.00 \mathrm{E}+00$ \\
\hline 90 & $5.20 \mathrm{E}+00$ & $0.00 \mathrm{E}+00$ & $0.00 \mathrm{E}+00$ & $0.00 \mathrm{E}+00$ & $0.00 \mathrm{E}+00$ \\
\hline 100 & $3.39 \mathrm{E}+00$ & $0.00 \mathrm{E}+00$ & $0.00 \mathrm{E}+00$ & $0.00 E+00$ & $0.00 \mathrm{E}+00$ \\
\hline 110 & $1.39 \mathrm{E}+00$ & $0.00 \mathrm{E}+00$ & $0.00 \mathrm{E}+00$ & $0.00 \mathrm{E}+00$ & $0.00 \mathrm{E}+00$ \\
\hline 120 & $5.69 \mathrm{E}-01$ & $0.00 \mathrm{E}+00$ & $0.00 \mathrm{E}+00$ & $0.00 \mathrm{E}+00$ & $0.00 \mathrm{E}+00$ \\
\hline 130 & $2.33 \mathrm{E}-01$ & $0.00 \mathrm{E}+00$ & $0.00 \mathrm{E}+00$ & $0.00 E+00$ & $0.00 \mathrm{E}+00$ \\
\hline 140 & $9.54 \mathrm{E}-02$ & $0.00 E+00$ & $0.00 E+00$ & $0.00 \mathrm{E}+00$ & $0.00 \mathrm{E}+00$ \\
\hline 150 & $3.91 \mathrm{E}-02$ & $0.00 \mathrm{E}+00$ & $0.00 \mathrm{E}+00$ & $0.00 \mathrm{E}+00$ & $0.00 \mathrm{E}+00$ \\
\hline 160 & $1.60 \mathrm{E}-02$ & $0.00 \mathrm{E}+00$ & $0.00 E+00$ & $0.00 \mathrm{E}+00$ & $0.00 \mathrm{E}+00$ \\
\hline 170 & $6.56 \mathrm{E}-03$ & $0.00 \mathrm{E}+00$ & $0.00 \mathrm{E}+00$ & $0.00 \mathrm{E}+00$ & $0.00 \mathrm{E}+00$ \\
\hline 180 & $2.69 \mathrm{E}-03$ & $0.00 \mathrm{E}+00$ & $0.00 \mathrm{E}+00$ & $0.00 \mathrm{E}+00$ & $0.00 \mathrm{E}+00$ \\
\hline 190 & $1.10 \mathrm{E}-03$ & $0.00 \mathrm{E}+00$ & $0.00 \mathrm{E}+00$ & $0.00 \mathrm{E}+00$ & $0.00 \mathrm{E}+00$ \\
\hline 200 & $4.51 \mathrm{E}-04$ & $0.00 \mathrm{E}+00$ & $0.00 \mathrm{E}+00$ & $0.00 E+00$ & $0.00 \mathrm{E}+00$ \\
\hline 210 & $1.85 \mathrm{E}-04$ & $0.00 \mathrm{E}+00$ & $0.00 \mathrm{E}+00$ & $0.00 E+00$ & $0.00 \mathrm{E}+00$ \\
\hline 220 & $7.56 \mathrm{E}-05$ & $0.00 \mathrm{E}+00$ & $0.00 \mathrm{E}+00$ & $0.00 \mathrm{E}+00$ & $0.00 \mathrm{E}+00$ \\
\hline 230 & $3.10 \mathrm{E}-05$ & $0.00 \mathrm{E}+00$ & $0.00 \mathrm{E}+00$ & $0.00 \mathrm{E}+00$ & $0.00 \mathrm{E}+00$ \\
\hline 240 & $1.27 \mathrm{E}-05$ & $0.00 \mathrm{E}+00$ & $0.00 E+00$ & $0.00 \mathrm{E}+00$ & $0.00 \mathrm{E}+00$ \\
\hline 250 & $5.20 \mathrm{E}-06$ & $0.00 E+00$ & $0.00 E+00$ & $0.00 \mathrm{E}+00$ & $0.00 \mathrm{E}+00$ \\
\hline
\end{tabular}




\begin{tabular}{|c|c|c|c|c|c|}
\hline \multirow{2}{*}{$\begin{array}{c}\text { Time } \\
\text { (years) }\end{array}$} & \multicolumn{5}{|c|}{ Concentration (pCi/L per pCi/g) } \\
\cline { 2 - 6 } & Sr-90 & U-234 & U-235 & U-238 & Ra-226 \\
\hline \hline 260 & $2.13 \mathrm{E}-06$ & $0.00 \mathrm{E}+00$ & $0.00 \mathrm{E}+00$ & $0.00 \mathrm{E}+00$ & $0.00 \mathrm{E}+00$ \\
\hline 270 & $8.71 \mathrm{E}-07$ & $0.00 \mathrm{E}+00$ & $0.00 \mathrm{E}+00$ & $0.00 \mathrm{E}+00$ & $0.00 \mathrm{E}+00$ \\
\hline 280 & $3.57 \mathrm{E}-07$ & $7.16 \mathrm{E}-01$ & $7.16 \mathrm{E}-01$ & $0.00 \mathrm{E}+00$ & $3.94 \mathrm{E}-09$ \\
\hline 290 & $1.46 \mathrm{E}-07$ & $1.60 \mathrm{E}+00$ & $1.60 \mathrm{E}+00$ & $3.65 \mathrm{E}-01$ & $1.37 \mathrm{E}-08$ \\
\hline 300 & $5.98 \mathrm{E}-08$ & $2.37 \mathrm{E}+00$ & $2.37 \mathrm{E}+00$ & $7.79 \mathrm{E}-01$ & $5.71 \mathrm{E}-08$ \\
\hline 310 & $2.45 \mathrm{E}-08$ & $3.07 \mathrm{E}+00$ & $3.07 \mathrm{E}+00$ & $1.15 \mathrm{E}+00$ & $1.20 \mathrm{E}-07$ \\
\hline 320 & $1.00 \mathrm{E}-06$ & $3.68 \mathrm{E}+00$ & $3.68 \mathrm{E}+00$ & $1.48 \mathrm{E}+00$ & $2.34 \mathrm{E}-07$ \\
\hline 330 & $4.11 \mathrm{E}-09$ & $4.23 \mathrm{E}+00$ & $4.23 \mathrm{E}+00$ & $1.77 \mathrm{E}+00$ & $3.77 \mathrm{E}-07$ \\
\hline 340 & $1.68 \mathrm{E}-09$ & $4.71 \mathrm{E}+00$ & $4.71 \mathrm{E}+00$ & $2.03 \mathrm{E}+00$ & $5.81 \mathrm{E}-07$ \\
\hline 350 & $6.89 \mathrm{E}-10$ & $5.14 \mathrm{E}+00$ & $5.14 \mathrm{E}+00$ & $2.26 \mathrm{E}+00$ & $8.55 \mathrm{E}-07$ \\
\hline 360 & $2.82 \mathrm{E}-10$ & $5.52 \mathrm{E}+00$ & $5.52 \mathrm{E}+00$ & $2.47 \mathrm{E}+00$ & $1.20 \mathrm{E}-06$ \\
\hline 370 & $1.15 \mathrm{E}-10$ & $5.86 \mathrm{E}+00$ & $5.86 \mathrm{E}+00$ & $2.66 \mathrm{E}+00$ & $1.60 \mathrm{E}-06$ \\
\hline 380 & $4.72 \mathrm{E}-11$ & $6.16 \mathrm{E}+00$ & $6.16 \mathrm{E}+00$ & $2.82 \mathrm{E}+00$ & $2.09 \mathrm{E}-06$ \\
\hline 390 & $1.93 \mathrm{E}-11$ & $6.42 \mathrm{E}+00$ & $6.42 \mathrm{E}+00$ & $2.97 \mathrm{E}+00$ & $2.65 \mathrm{E}-06$ \\
\hline 400 & $7.92 \mathrm{E}-12$ & $6.66 \mathrm{E}+00$ & $6.66 \mathrm{E}+00$ & $3.10 \mathrm{E}+00$ & $3.29 \mathrm{E}-06$ \\
\hline 410 & $3.24 \mathrm{E}-12$ & $6.87 \mathrm{E}+00$ & $6.87 \mathrm{E}+00$ & $3.21 \mathrm{E}+00$ & $4.02 \mathrm{E}-06$ \\
\hline 420 & $1.33 \mathrm{E}-12$ & $7.05 \mathrm{E}+00$ & $7.05 \mathrm{E}+00$ & $3.32 \mathrm{E}+00$ & $4.85 \mathrm{E}-06$ \\
\hline 430 & $5.43 \mathrm{E}-13$ & $7.22 \mathrm{E}+00$ & $7.22 \mathrm{E}+00$ & $3.41 \mathrm{E}+00$ & $5.74 \mathrm{E}-06$ \\
\hline 440 & $2.22 \mathrm{E}-13$ & $7.36 \mathrm{E}+00$ & $7.36 \mathrm{E}+00$ & $3.49 \mathrm{E}+00$ & $6.74 \mathrm{E}-06$ \\
\hline 450 & $9.09 \mathrm{E}-14$ & $7.49 \mathrm{E}+00$ & $7.49 \mathrm{E}+00$ & $3.56 \mathrm{E}+00$ & $7.83 \mathrm{E}-06$ \\
\hline 460 & $3.72 \mathrm{E}-14$ & $7.61 \mathrm{E}+00$ & $7.61 \mathrm{E}+00$ & $3.63 \mathrm{E}+00$ & $9.02 \mathrm{E}-06$ \\
\hline 470 & $1.52 \mathrm{E}-14$ & $7.71 \mathrm{E}+00$ & $7.71 \mathrm{E}+00$ & $3.69 \mathrm{E}+00$ & $1.03 \mathrm{E}-05$ \\
\hline 480 & $6.23 \mathrm{E}-15$ & $7.80 \mathrm{E}+00$ & $7.80 \mathrm{E}+00$ & $3.74 \mathrm{E}+00$ & $1.16 \mathrm{E}-05$ \\
\hline 490 & $2.55 \mathrm{E}-15$ & $7.88 \mathrm{E}+00$ & $7.88 \mathrm{E}+00$ & $3.78 \mathrm{E}+00$ & $1.31 \mathrm{E}-05$ \\
\hline 500 & $1.04 \mathrm{E}-15$ & $7.95 \mathrm{E}+00$ & $7.95 \mathrm{E}+00$ & $3.83 \mathrm{E}+00$ & $1.47 \mathrm{E}-05$ \\
\hline 510 & $4.27 \mathrm{E}-16$ & $8.01 \mathrm{E}+00$ & $8.01 \mathrm{E}+00$ & $3.86 \mathrm{E}+00$ & $1.63 \mathrm{E}-05$ \\
\hline 520 & $1.75 \mathrm{E}-16$ & $8.07 \mathrm{E}+00$ & $8.07 \mathrm{E}+00$ & $3.89 \mathrm{E}+00$ & $1.81 \mathrm{E}-05$ \\
\hline 530 & $7.15 \mathrm{E}-17$ & $8.12 \mathrm{E}+00$ & $8.12 \mathrm{E}+00$ & $3.92 \mathrm{E}+00$ & $2.00 \mathrm{E}-05$ \\
\hline & & & & & \\
\hline & & &
\end{tabular}




\begin{tabular}{|c|c|c|c|c|c|}
\hline \multirow{2}{*}{$\begin{array}{c}\text { Time } \\
\text { (years) }\end{array}$} & \multicolumn{5}{|c|}{ Concentration (pCi/L per $\mathrm{pCi} / \mathrm{g}$ ) } \\
\hline & Sr-90 & U-234 & $\mathrm{U}-235$ & U-238 & Ra-226 \\
\hline 540 & $2.93 \mathrm{E}-17$ & $8.16 \mathrm{E}+00$ & $8.16 E+00$ & $3.95 \mathrm{E}+00$ & 2.19 E-05 \\
\hline 550 & $1.20 \mathrm{E}-17$ & $7.28 \mathrm{E}+00$ & $7.28 \mathrm{E}+00$ & $3.97 \mathrm{E}+00$ & $2.40 \mathrm{E}-05$ \\
\hline 560 & $4.90 \mathrm{E}-18$ & $6.46 \mathrm{E}+00$ & $6.46 \mathrm{E}+00$ & $3.99 \mathrm{E}+00$ & $2.62 \mathrm{E}-05$ \\
\hline 570 & $2.00 \mathrm{E}-18$ & $5.73 E+00$ & $5.73 E+00$ & $4.01 E+00$ & $2.83 \mathrm{E}-05$ \\
\hline 580 & 8.19 E-19 & $5.08 \mathrm{E}+00$ & $5.08 \mathrm{E}+00$ & $4.03 E+00$ & $3.06 \mathrm{E}-05$ \\
\hline 590 & $3.35 \mathrm{E}-19$ & $4.51 E+00$ & $4.51 E+00$ & $4.04 E+00$ & $3.29 \mathrm{E}-05$ \\
\hline 600 & $1.37 \mathrm{E}-19$ & $4.00 \mathrm{E}+00$ & $4.00 \mathrm{E}+00$ & $4.05 \mathrm{E}+00$ & $3.54 \mathrm{E}-05$ \\
\hline 610 & $5.61 \mathrm{E}-20$ & $3.55 \mathrm{E}+00$ & $3.55 \mathrm{E}+00$ & $4.07 \mathrm{E}+00$ & $3.78 \mathrm{E}-05$ \\
\hline 620 & $2.29 \mathrm{E}-20$ & $3.15 \mathrm{E}+00$ & $3.15 E+00$ & $4.08 \mathrm{E}+00$ & $4.02 \mathrm{E}-05$ \\
\hline 630 & $9.38 \mathrm{E}-21$ & $2.80 E+00$ & $2.79 \mathrm{E}+00$ & $4.08 \mathrm{E}+00$ & $4.27 \mathrm{E}-05$ \\
\hline 640 & $3.84 \mathrm{E}-21$ & $2.48 \mathrm{E}+00$ & $2.48 \mathrm{E}+00$ & $4.09 \mathrm{E}+00$ & 4.52 E-05 \\
\hline 650 & $1.57 \mathrm{E}-21$ & $2.20 \mathrm{E}+00$ & $2.20 E+00$ & $4.10 \mathrm{E}+00$ & $4.78 \mathrm{E}-05$ \\
\hline 660 & $6.41 \mathrm{E}-22$ & $1.95 \mathrm{E}+00$ & $1.95 \mathrm{E}+00$ & $4.11 \mathrm{E}+00$ & 5.03 E-05 \\
\hline 670 & $2.62 \mathrm{E}-22$ & $1.73 \mathrm{E}+00$ & $1.73 E+00$ & $4.11 E+00$ & $5.28 \mathrm{E}-05$ \\
\hline 680 & $1.07 \mathrm{E}-22$ & $1.54 \mathrm{E}+00$ & $1.53 \mathrm{E}+00$ & $4.12 \mathrm{E}+00$ & 5.54 E-05 \\
\hline 690 & $4.38 \mathrm{E}-23$ & $1.36 \mathrm{E}+00$ & $1.36 \mathrm{E}+00$ & $4.12 \mathrm{E}+00$ & $5.81 \mathrm{E}-05$ \\
\hline 700 & $1.79 \mathrm{E}-23$ & $1.21 \mathrm{E}+00$ & $1.20 E+00$ & $4.12 E+00$ & $6.06 \mathrm{E}-05$ \\
\hline 710 & 7.33 E-24 & $1.07 \mathrm{E}+00$ & $1.07 \mathrm{E}+00$ & $4.13 E+00$ & $6.32 \mathrm{E}-05$ \\
\hline 720 & $3.00 \mathrm{E}-24$ & $9.52 \mathrm{E}-01$ & $9.47 \mathrm{E}-01$ & $4.13 \mathrm{E}+00$ & $6.58 \mathrm{E}-05$ \\
\hline 730 & $1.22 \mathrm{E}-24$ & 8.44 E-01 & 8.40 E-01 & $4.13 E+00$ & $6.84 \mathrm{E}-05$ \\
\hline 740 & $5.00 \mathrm{E}-25$ & 7.49 E- 01 & $7.45 \mathrm{E}-01$ & $4.14 E+00$ & $7.10 \mathrm{E}-05$ \\
\hline 750 & $2.05 \mathrm{E}-25$ & 6.64 E-01 & $6.60 \mathrm{E}-01$ & $4.14 \mathrm{E}+00$ & $7.36 \mathrm{E}-05$ \\
\hline 760 & $8.39 \mathrm{E}-26$ & $5.89 \mathrm{E}-01$ & $5.85 \mathrm{E}-01$ & $4.14 \mathrm{E}+00$ & $7.62 \mathrm{E}-05$ \\
\hline 770 & $3.42 \mathrm{E}-26$ & $5.23 \mathrm{E}-01$ & $5.19 \mathrm{E}-01$ & $4.14 \mathrm{E}+00$ & $7.88 \mathrm{E}-05$ \\
\hline 780 & $1.40 \mathrm{E}-26$ & 4.64 E-01 & 4.60 E-01 & $4.14 E+00$ & 8.14 E-05 \\
\hline 790 & $5.71 \mathrm{E}-27$ & 4.11 E-01 & $4.08 \mathrm{E}-01$ & $4.15 \mathrm{E}+00$ & $8.40 \mathrm{E}-05$ \\
\hline 800 & $2.33 \mathrm{E}-27$ & 3.65 E-01 & $3.62 \mathrm{E}-01$ & $4.15 \mathrm{E}+00$ & $8.65 \mathrm{E}-05$ \\
\hline 810 & $9.52 \mathrm{E}-28$ & 3.24 E-01 & $3.21 \mathrm{E}-01$ & $4.15 E+00$ & 8.90 E-05 \\
\hline
\end{tabular}




\begin{tabular}{|c|c|c|c|c|c|}
\hline \multirow{2}{*}{$\begin{array}{l}\text { Time } \\
\text { (years) }\end{array}$} & \multicolumn{5}{|c|}{ Concentration (pCi/L per pCi/g) } \\
\hline & Sr-90 & U-234 & $\mathrm{U}-235$ & $\mathrm{U}-238$ & Ra-226 \\
\hline 820 & $3.89 \mathrm{E}-28$ & $2.87 \mathrm{E}-01$ & $2.84 \mathrm{E}-01$ & $4.15 \mathrm{E}+00$ & $9.19 \mathrm{E}-05$ \\
\hline 830 & $1.59 \mathrm{E}-28$ & $2.54 \mathrm{E}-01$ & $2.52 \mathrm{E}-01$ & $4.15 \mathrm{E}+00$ & $9.41 \mathrm{E}-05$ \\
\hline 840 & $6.49 \mathrm{E}-29$ & $2.26 \mathrm{E}-01$ & $2.26 \mathrm{E}-01$ & $4.15 E+00$ & $9.66 \mathrm{E}-05$ \\
\hline 850 & $2.65 \mathrm{E}-29$ & $2.00 \mathrm{E}-01$ & $1.98 \mathrm{E}-01$ & $4.10 \mathrm{E}+00$ & $9.92 \mathrm{E}-05$ \\
\hline 860 & $1.08 \mathrm{E}-29$ & $1.77 \mathrm{E}-01$ & $1.75 \mathrm{E}-01$ & $3.65 \mathrm{E}+00$ & $1.02 \mathrm{E}-04$ \\
\hline 870 & $4.43 \mathrm{E}-30$ & $1.57 \mathrm{E}-01$ & $1.55 \mathrm{E}-01$ & $3.26 E+00$ & $1.04 \mathrm{E}-04$ \\
\hline 880 & $1.81 \mathrm{E}-30$ & $1.39 \mathrm{E}-01$ & $1.38 \mathrm{E}-01$ & $2.90 E+00$ & $1.07 \mathrm{E}-04$ \\
\hline 890 & $7.38 \mathrm{E}-31$ & $1.24 \mathrm{E}-01$ & $1.22 \mathrm{E}-01$ & $2.58 \mathrm{E}+00$ & $1.09 \mathrm{E}-04$ \\
\hline 900 & $3.01 \mathrm{E}-31$ & $1.09 \mathrm{E}-01$ & $1.08 \mathrm{E}-01$ & $2.30 \mathrm{E}+00$ & $1.12 \mathrm{E}-04$ \\
\hline 910 & $1.23 \mathrm{E}-31$ & $9.70 \mathrm{E}-02$ & $9.59 \mathrm{E}-02$ & $2.05 E+00$ & $1.14 \mathrm{E}-04$ \\
\hline 920 & $5.02 \mathrm{E}-32$ & $8.60 \mathrm{E}-02$ & 8.50 E-02 & $1.82 E+00$ & $1.17 \mathrm{E}-04$ \\
\hline 930 & $2.05 \mathrm{E}-32$ & $7.62 \mathrm{E}-02$ & 7.53 E-02 & $1.62 E+00$ & $1.19 \mathrm{E}-04$ \\
\hline 940 & $8.37 \mathrm{E}-33$ & $6.75 \mathrm{E}-02$ & $6.67 \mathrm{E}-02$ & $1.45 \mathrm{E}+00$ & $1.21 \mathrm{E}-04$ \\
\hline 950 & $3.42 \mathrm{E}-33$ & $5.99 \mathrm{E}-02$ & $5.91 \mathrm{E}-02$ & $1.29 \mathrm{E}+00$ & $1.24 \mathrm{E}-04$ \\
\hline 960 & $1.40 \mathrm{E}-33$ & $5.30 \mathrm{E}-02$ & 5.24 E-02 & $1.15 E+00$ & $1.26 \mathrm{E}-04$ \\
\hline 970 & $5.69 \mathrm{E}-34$ & $4.70 \mathrm{E}-02$ & $4.64 \mathrm{E}-02$ & $1.02 \mathrm{E}+00$ & $1.29 \mathrm{E}-04$ \\
\hline 980 & $2.32 \mathrm{E}-34$ & $4.17 \mathrm{E}-02$ & $4.11 \mathrm{E}-02$ & $9.09 \mathrm{E}-01$ & $1.31 \mathrm{E}-04$ \\
\hline 990 & 9.48 E-35 & $3.69 \mathrm{E}-02$ & $3.64 \mathrm{E}-02$ & $8.10 \mathrm{E}-01$ & $1.33 \mathrm{E}-04$ \\
\hline 1000 & & & & & \\
\hline
\end{tabular}




\subsection{RISK OPTIMIZATION (ALARA) ANALYSIS ASSOCIATED WITH LARGE- SCALE EXCAVATION AND OFF-SITE DISPOSAL OF CONTAMINATED SOIL}

To make an informed decision about remediating a site contaminated with radioactive materials, it is essential that decision-makers are provided with facts on the costs, benefits, risks, and other societal and political considerations. To do this, a decision-management tool was employed to evaluate the net benefit both quantitatively and qualitatively. This decisionmaking tool, developed at Brookhaven National Laboratory's ALARA Center, is a software application called Radiological Assessment \& Design System (RADS) or simply RADS Version 2.0 (Dionne 1994). One module in this software package determines if a protective measure that reduces radiation exposure is reasonably achievable or ALARA. It was used to calculate the net benefit of the excavation and off-site disposal vs. the no-action remedial alternative. In addition, the qualitative factor analysis in this software gives decision-makers the other societal, technical, and political factors needed to make an informed decision.

A methodology is evolving within DOE to evaluate the final risk-based remediation goal that will result in radiation exposures being as low as reasonably achievable. It requires using risk-assessment models to estimate present and future risks to both workers and the public for the current and expected land use of the contaminated area. It also requires data on how the radionuclide concentrations at the site will vary in time and space over this period (see section 2.0). Basically, the analysis involved determining the volume of soil, which is a surrogate for the costs to remediate, over the range of measured radionuclide concentration, which is a surrogate for the radiological risks. These volume/cost estimates increased dramatically below a certain concentration/risk ratio. The optimum (ALARA) level is traditionally defined as the point where the ratio of the differential cost for remediation and the differential risk is a minimum.

Figure 3.3-1 displays the costs and net fatalities for excavation and disposal. Selecting a risk-based remediation goal just below the $100 \mathrm{mrem} / \mathrm{yr}$ limit involves the cleanup of a relatively small volume of soil, while, at the same time, there is a relatively small chance for a fatality. As the soil-remediation goal was made more stringent i.e., decrease in the DCGL, the volume of soil increased rapidly, but the chance for a fatality being avoided decreased, or, in other words, the probability for a fatality increased rapidly. Since there is no clear optimum remediation level (differential cost to risk ratio of zero), the traditional optimum risk level cannot be defined. Instead, the optimum (ALARA) level will be defined as the value of the risk-based remediation goal where costs and the number of deaths caused by remediation begins to increase dramatically (see Figure 3.3-1). This ALARA level also corresponds to the point where the volume of contaminated soil to be remediated begin to increase dramatically. 
The final remediation level selected by the decision-makers would also factor in some of the qualitative factors described in Section 3.7. The process and the rationale that were used for risk-optimization (ALARA) analysis are discussed in Sections 3.1 through 3.7 .

\subsection{Description of Radiological Conditions and the Remedial Alternative}

For this net-benefit analysis, the present radiological conditions at the contaminated site and the remedial alternative were described as follows (see Appendix J, Attachment 1 for the RADS Version 2 - Radiological Problem Definition Worksheet). The operations at the HWMF, from 1947 to 1996, released radioactive material to the environment through accidental spills, overflows of radioactive waste tanks and containers, leaking waste containers, runoff from activated or contaminated equipment, and from local radioactive fallout from BNL operations. As a result the soil was contaminated with long-lived mixed fission and activation products (see Appendix $\mathrm{C}$ for contaminated soil volumes and radionuclide concentrations). Dose rates at waist level over the soil were as high as $6 \mathrm{mR} / \mathrm{hr}$. A fence prevents access to the radiological area.

The remedial alternative is large scale excavation with off-site disposal of contaminated soil above the various risk-based derived concentration guideline levels. . The volumes of soil that were excavated contained predominately cesium- 137 and strontium- 90 . The volumes of soil associated with the various risk-based remediation goals/limit are shown in Appendix C. The soil that had levels above $2,800 \mathrm{pCi} / \mathrm{g}$ was stabilized by mixing it with Portland cement and pouring it into B-25 steel containers. The remaining contaminated soil was also loaded into B-25 steel containers that were then safely stored at an on-site low-levelwaste storage facility. Subsequently, the low-level soil was transported by a flatbed trailertruck to the Envirocare TSD facility located in Givens, Utah (waste concentrations from 67 $\mathrm{pCi} / \mathrm{g}$ to $2,800 \mathrm{pCi} / \mathrm{g}$ ) and the stabilized waste by sole-source vehicle to Fluor Daniels Hanford in Richland, Washington (waste concentrations greater than $2800 \mathrm{pCi} / \mathrm{g}$ ) for off-site disposal.

The relevant time frame for estimating cost elements and radiation exposure was 270 years. The large-scale excavation and off-site disposal of contaminated soil was assumed to occur in 1999. From 1997 to 2047 the present workers obtained monitoring well samples and performed security/safety inspections. The property was assumed to be under the control of the Department of Energy until 2047. If no remedial action was taken, a post-closure groundwater monitoring program would be conducted from 2047 to 2077 . From 2047 to 2317 the property was assumed to be undeveloped open-space and was assumed to have 30 visitors, hunting, hiking, observing nature, and cross-country skiing. Other dose assessment assumptions and results were described in Chapter 2. 


\subsection{Cost Savings from the Remediation}

The cost savings associated with implementing the remedial alternative are minimal, e.g., savings in maintenance labor, operations labor, inspection labor, production, processing, salvage, reduced chemicals, reduced consumables, and reduced radioactive waste (see worksheet from the RADS Version 2 software application in Appendix J, Attachment 3 ALARA Protective Measure (APM) Benefit Calculation).

The two main expected cost-savings that result from removing the radioactive source were (1) the three monitoring wells would not have to be sampled after 5 years following remediation, and (2) the potential real-estate value of this property. For the first savings it was assumed that remediation was completed in 1999; it was also assumed that the results of radiochemical analysis after 5 years would show that levels of radioactivity in the groundwater were low and decreasing. This resulted in groundwater monitoring being terminated prematurely, i.e., there was no monitoring for the 43 remaining years of federal control plus the 30-year post-closure that is required by NYS-DEC's solid waste regulations. The termination of monitoring, analysis, and reporting of three wells at $\$ 1,000$ per well per year for 73 years saved $\$ 219,000$.

The second main savings was the potential real-estate proceeds from the sale of the property to the Pine Barren Preserve Association or Suffolk County. In this area of Brookhaven Township, real-estate is selling for approximately $\$ 50,000$ per acre (Newsday, 1997). Since the HWMF site consists of 12 acres, this land was assumed to have a postremediation value or savings of $\$ 600,000$. If this property was not remediated, it would not be expected to be purchased, i.e., no real-estate value.

The cost savings for all the risk-based remediation goals/limit were $\$ 819,000$ (1997 value).

\subsection{Cost to Excavate, Package, Ship, and Dispose of the Contaminated Soil}

The costs for implementing the remedial alternative, e.g., design and engineering, equipment procurement, fabrication, installation or construction labor, operation, maintenance, associated training and procedure, additional chemicals, additional consumables, special tools, additional radioactive waste, as well as the costs to decontaminate, decommission, dispose of, and then restore the environment during facility/system closure were also estimated (see worksheet in Appendix J, Attachment 4 -APM Cost Calculation Worksheet).

The estimated capital cost plus the present (1997) worth of operating and maintenance expenses for excavation and off-site disposal was $\$ 64,728,030$ to clean up to the $1 \mathrm{mrem} / \mathrm{yr}$ risk-based remediation goal, $\$ 28,650,610$ to $15 \mathrm{mrem} / \mathrm{yr}, \$ 24,826,660$ to $25 \mathrm{mrem} / \mathrm{yr}$, $\$ 17,102,970$ to $75 \mathrm{mrem} / \mathrm{yr}$, and $\$ 16,420,860$ to the $100 \mathrm{mrem} / \mathrm{yr}$ limit. The periodic 
operating and maintenance expenses were included in this total and were converted to present worth in 1997 dollars using a 3\% discount rate (USNRC 1995). The present worth for longterm radiological environmental and ecological monitoring programs/reports, the CERCLA/RCRA post-closure monitoring program/reports, and HWMF site maintenance and security inspections were $\$ 457,640$. Table 3.3-1 lists and Figure 3.3-1 displays graphically the total cost to remediate to the various risk-base remediation goals/limit.

Table 3.3-1 Cost to Remediate at Various Remediation Goals/Limit

\begin{tabular}{|c|c|}
\hline $\begin{array}{c}\text { Risk-Based Remediation Goals/Limit } \\
\text { (mrem/yr) }\end{array}$ & $\begin{array}{c}\text { Remediation Costs } \\
\text { (1997 Dollars) }\end{array}$ \\
\hline 1 & $\$ 64,728,030$ \\
\hline 15 & $\$ 28,650,610$ \\
\hline 25 & $\$ 24,826,660$ \\
\hline 75 & $\$ 17,102,970$ \\
\hline 100 & $\$ 16,420,860$ \\
\hline
\end{tabular}

Figure 3.3-1 Optimization of Protection Costs and Hypothetical Fatalities at BNL's Hazardous Waste Management Facility

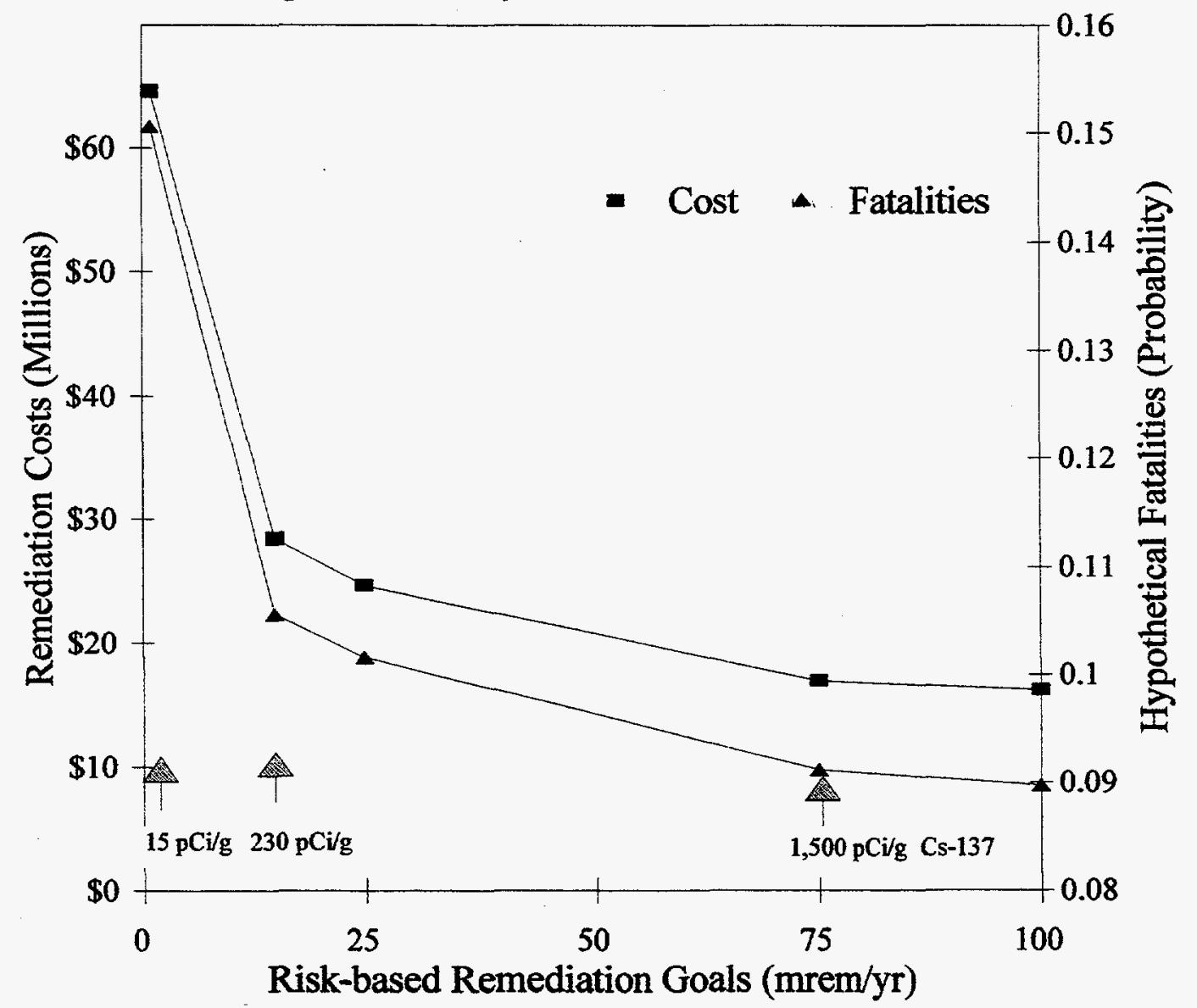




\subsection{Radiation Dose Averted to Workers, Visitors, and Public}

Next, we estimated the collective doses without remedial action, and those with the remedial action, to implement the remedial action, and to handle, transport and dispose of the contaminated soil (see worksheet in Appendix J, Attachment 5 - Estimated Radiation Dose to be Avoided). The ranges of collective doses for the various risk-based remediation goals/imit were calculated using two soil concentrations (see Section 2.0). These were the volumeweighted geometric average for the lower limit and volume-weighted arithmetic average for the upper limit. The upper limit of these collective dose ranges were used as the collective dose for calculating the dollar value of the collective doses to be averted by remediation.

The dose to the present BNL workers to sample the three monitoring wells ( 4.32 person-rem) and for grounds security/safety inspections $(0.016$ person-rem) were estimated to be about 4.34 person-rem with no environmental remediation, i.e., existing radiological conditions (see Section 2.1.1). The collective doses to sample the monitoring wells and for grounds security/safety inspections after remediation were estimated to be 0.24 person-rem at the $1 \mathrm{mrem} / \mathrm{yr}$ remediation goal, 0.28 person-rem at $15 \mathrm{mrem} / \mathrm{yr}, 0.33$ person-rem at 25 mrem/yr, 0.46 person-rem at $75 \mathrm{mrem} / \mathrm{yr}$, and 0.52 person-rem at the $100 \mathrm{mrem} / \mathrm{yr}$ dose limit (see Section 2.1.2).

The collective doses to workers from excavating, packaging, transporting, and storing of the contaminated soil from the HWMF onsite were calculated. The dose assessment indicated that 203 person-rem would be received for remediation to the $1 \mathrm{mrem} / \mathrm{yr}$ risk-based remediation goal; 199 person-rem at $15 \mathrm{mrem} / \mathrm{yr} ; 199 \mathrm{person}-\mathrm{rem}$ at $25 \mathrm{mrem} / \mathrm{yr} ; 195 \mathrm{person}$ $\mathrm{rem}$ at $75 \mathrm{mrem} / \mathrm{yr}$, and 194 person-rem at $100 \mathrm{mrem} / \mathrm{yr}$ dose limit (see Section 2.1.3). The collective doses to drivers/workers from waste handling, transporting, disposing, and inspecting were calculated. The dose assessment indicated 19.6 person-rem would be received at the $1 \mathrm{mrem} / \mathrm{yr}$ risk-based remediation goal; 19.2 person-rem at $15 \mathrm{mrem} / \mathrm{yr} ; 19.1$ person-rem at $25 \mathrm{mrem} / \mathrm{yr} ; 18.4$ person-rem at $75 \mathrm{mrem} / \mathrm{yr}$ and 18.3 person-rem at 100 mrem/yr dose limit (see Section 2.1.4).

The collective dose averted or expended (negative) by workers for the various remediation goals/limit are summarized in Table 3.4-1. It was assumed that, for a worker, the value of the radiation detriment for a unit of radiation dose was $\$ 2,000$ per person-rem.

The collective dose to 30 visitors to this open space over this 270-year future-use period without remediation was about 8.6 person-rem (see Section 2.2.1). The collective doses to the future visitors who frequent the former HWMF site for 270-year after remediation were estimated to be 0.004 at the $1 \mathrm{mrem} / \mathrm{yr}$ risk-based remediation goal, 0.060 at $15 \mathrm{mrem} / \mathrm{yr}, 0.100$ at $25 \mathrm{mrem} / \mathrm{yr}, 0.302$ at $75 \mathrm{mrem} / \mathrm{yr}$, and 0.402 person-rem at the 100 $\mathrm{mrem} / \mathrm{yr}$ limit (see Section 2.2.2). Population doses resulting from site remediation, expressed in terms of the collective dose for the first year of exposure following excavation were $6.20 \mathrm{E}$ 04 person-rem for cleanup to $1 \mathrm{mrem} / \mathrm{yr}$ risk-based cleanup goal, $4.68 \mathrm{E}-04$ person-rem for 15 
mrem/yr, 4.70 E-04 person-rem for $25 \mathrm{mrem} / \mathrm{yr}, 4.56 \mathrm{E}-04$ person-rem for $75 \mathrm{mrem} / \mathrm{yr}$, and $4.54 \mathrm{E}-04$ person-rem for $100 \mathrm{mrem} / \mathrm{yr}$ limit (see Section 2.2.3). The collective dose impact to the public resulting from off-site transportation and disposal was 6.68 person-rem at the 1 $\mathrm{mrem} / \mathrm{yr}$ risk-based remediation goal; 6.54 person-rem at $15 \mathrm{mrem} / \mathrm{yr} ; 6.50$ person-rem at 25 $\mathrm{mrem} / \mathrm{yr} ; 6.31$ person-rem at $75 \mathrm{mrem} / \mathrm{yr}$; and person-rem at the $100 \mathrm{mrem} / \mathrm{yr}$ dose limit (see Section 2.2.4).

The collective dose averted or expended (negative) by the public for the various remediation goals/limit are summarized in Table 3.4-1. It was assumed that, for the public, the value of the radiation detriment for a unit of radiation dose was $\$ 2,000$ per person-rem (USNRC 1995).

Table 3.4-1 shows that the net radiation dose averted or expended (negative) from the remediation of the HWMF was - 217 person-rem at the $1 \mathrm{mrem} / \mathrm{yr}$ risk-based remediation goal; - 212 person-rem at $15 \mathrm{mrem} / \mathrm{yr} ;-212$ person-rem at $25 \mathrm{mrem} / \mathrm{yr} ;-207$ person-rem at $75 \mathrm{mrem} / \mathrm{yr}$; and - 206 person-rem at the $100 \mathrm{mrem} / \mathrm{yr}$ dose limit (see Section 2.2.4).

Table 3.4-1 Net Radiation Dose Averted or Expended at Various Remediation Goals/Limit

\begin{tabular}{|c|c|c|c|}
\hline $\begin{array}{c}\text { Risk-Based } \\
\text { Remediation } \\
\text { Goals/Limit } \\
\text { (mrem/yr) }\end{array}$ & $\begin{array}{c}\text { Net Collective } \\
\text { Dose to Workers } \\
\text { (person-rem) }\end{array}$ & $\begin{array}{c}\text { Net Collective } \\
\text { Dose to Public } \\
\text { (person-rem) }\end{array}$ & $\begin{array}{c}\text { Net Collective } \\
\text { Dose from } \\
\text { Remediation } \\
\text { (person-rem) }\end{array}$ \\
\hline 1 & -219 & 1.87 & -217 \\
\hline 15 & -214 & 1.95 & -212 \\
\hline 25 & -214 & 1.95 & -212 \\
\hline 75 & -209 & 1.94 & -207 \\
\hline 100 & -208 & 1.87 & -206 \\
\hline
\end{tabular}

The dollar values for the radiation dose to be averted or expended (negative) by the cleanup to the various remediation goals/limit are listed below in Table 3.4-2. Based on $\$ 2,000$ per person-rem, the radiation dose expended from remediation has a value of $\$-434,000$ to $\$-412,000$ over the remediation goal/limit range of 1 to $100 \mathrm{mrem} / \mathrm{yr}$. 
Table 3.4-2 Value of Radiation Dose Averted or Expended at Various Remediation Goals/Limit

\begin{tabular}{|c|c|}
\hline $\begin{array}{c}\text { Risk-based Remediation } \\
\text { Goals/Limit } \\
\text { (mrem/yr) }\end{array}$ & $\begin{array}{c}\text { Value of Radiation Dose Averted } \\
\text { or Expended } \\
\text { (1997 Dollars) }\end{array}$ \\
\hline 1 & $\$-434,000$ \\
\hline 15 & $\$-424,000$ \\
\hline 25 & $\$-424,000$ \\
\hline 75 & $\$-414,000$ \\
\hline 100 & $\$-412,000$ \\
\hline
\end{tabular}

\subsection{Value of Other Risks and Damages Avoided by Remediation}

Another important set of considerations in evaluating net benefits of remediation was the estimation of the potential value of the non-radiation risks and damages to be avoided; e.g., injury and death to remediation workers, environmental damage, public/worker concerns, litigation costs and civil penalties, and facility shutdown (see worksheet in Appendix J, Attachment 6 - Estimated Value of Risks and Damages Avoided Worksheet).

The risks and damages that could be expected from the remediation of the HWMF included (1) damage to wetlands and wildlife habitats, (2) worker's and public's concerns about no remedial actions, (3) construction fatalities to workers during excavating, packaging, and storing the contaminated soil on-site; (4) transportation fatalities resulting from transporting the waste to Utah and to Washington from Long Island, New York.

The following are the values of other risks and damages that were expected if no remedial action was taken, and if remedial action was taken:

1. Wetland contamination and unsuitability for use by wildlife associated with no remedial action: probability 1.0 and a value of $\$ 5,000$ yields a $\$ 5,000$ consequence (applies to no-action alternative);

2. Worker's and public's concern for no remedial action: probability of 0.9 and an estimated value of $\$ 120,000$ yields a $\$ 108,000$ consequence (applies to no action alternative);

3. Construction fatalities to remediation workers was estimated using a value of 4.2 $\mathrm{x} 10^{-8}$ fatal injuries per hour of work (USNRC 1997). Multiplying the various volumes of soil to be excavated and disposed of for the various remediation goals/limit by $1.62 \mathrm{hr} / \mathrm{m}^{3}$ (USNRC 1997) yielded $59,862 \mathrm{~m}^{3} \times 1.62 \mathrm{hr} / \mathrm{m}^{3}=$ 
$96,980 \mathrm{hrs}$ or 0.004 fatalities, $31,895 \mathrm{hrs}$ or 0.001 fatalities, $25,020 \mathrm{hrs}$ or 0.001 fatalities, $11,136 \mathrm{hrs}$ or 0.0005 fatalities, and $9,910 \mathrm{hrs}$ or 0.0004 fatalities. This yields at $\$ 4 \mathrm{M}$ per life (Guen 1997): $\$ 16,300, \$ 5,360, \$ 4,200, \$ 2,000$, and $\$$ 1,600 for the $1,15,25,75 \mathrm{mrem} / \mathrm{yr}$ remediation goals and the $100 \mathrm{mrem} / \mathrm{yr}$ limit, respectively (applies to remedial action alternative);

4. Transportation fatalities to the workers and public from transporting the contaminated soil to Envirocare and Hanford was estimated using a value of $4 x$ $10^{-9}$ occupant deaths per vehicle mile (USDOT 1991). Multiplying this value by the total mileage to transport the various volumes that require disposal for the various remediation goals/imit, namely $14,925,758$ miles or 0.06 fatalities, $5,097,148$ miles or 0.02 fatalities, $4,057,713$ miles or 0.016 fatalities, $1,958,638$ miles or 0.008 fatalities, and $1,774,548$ miles or 0.007 fatalities. This yields at $\$ 4 \mathrm{M}$ per life (Guen 1997): $\$ 240,000, \$ 80,000, \$ 64,000, \$ 32,000$, and $\$ 28,000$ for the $1,15,25,75 \mathrm{mrem} / \mathrm{yr}$ remediation goals, and the $100 \mathrm{mrem} / \mathrm{yr}$ limit, respectively (applies to remedial action alternative).

Table 3:5-1 lists the difference between the values for the no action risks and damages and those to be averted/caused (negative) by the cleanup to the various risk-based remediation goals /limit.

Table 3.5-1 Value of Other Risks and Damages Averted or Caused at Various Remediation Goals/Limit

\begin{tabular}{|c|c|}
\hline $\begin{array}{c}\text { Risk-based Remediation Goals/Limit } \\
\text { (mrem/yr) }\end{array}$ & $\begin{array}{c}\text { Value of Risks and Damages } \\
\text { Averted/Caused } \\
\text { (1997 Dollars) }\end{array}$ \\
\hline \hline 1 & $\$-143,300$ \\
\hline 15 & $\$ 27,640$ \\
\hline 25 & $\$ 44,800$ \\
\hline 75 & $\$ 79,000$ \\
\hline 100 & $\$ 83,400$ \\
\hline
\end{tabular}

\subsection{Net-Benefit Analysis}

The results of the net-benefit analysis for the $15 \mathrm{mrem} / \mathrm{yr}$ remediation goal (see Appendix J, Attachment 7) are as follows: 
1. Cost for excavation and disposal

2. Benefits from reduced well sampling and potential real-estate sale

3. Value of radiation dose averted

4. Value of other avoided risks and damages

Net Benefit/Cost
$\$-28,650,610$

$\$ \quad 819,000$

$\$ \quad-424,000$

$\$ \quad 27.640$

$\$-28,227,970$

Table 3.6-1 gives the net benefit/cost (negative) for the various risk-based remediation goals/limits. Based on risk avoidance and economic factors alone, it can be concluded that this remedial action or alternative is not reasonably achievable. However, since the DOE's public radiation dose limit in 10 CFR 834 is $100 \mathrm{mrem} / \mathrm{yr}$ and the EPA Comprehensive Environmental Response, Compensation, and Liability Act's (superfund) regulatory risk range for remedial action is 1 in ten thousand to one in a million, whatever costs are needed to comply with these Federal rules must be expended. The decisionmakers must decide what level below this limit is reasonable based on the net benefit and the other societal, technological and political factors. Section 3.7 Qualitative Factors Analysis describes these other factors.

Table 3.6-1 Net Benefit or Cost at Various Remediation Goals/Limit

\begin{tabular}{|c|c|}
\hline $\begin{array}{c}\text { Risk-based Remediation } \\
\text { Goals/Limit } \\
\text { (mrem/yr) }\end{array}$ & $\begin{array}{c}\text { Net-Benefit/Cost } \\
\text { (1997 Dollars) }\end{array}$ \\
\hline 1 & $\$-64,484,330$ \\
\hline 15 & $\$-28,227,970$ \\
\hline 25 & $\$-24,384,860$ \\
\hline 75 & $\$-16,616,970$ \\
\hline 100 & $\$-15,928,460$ \\
\hline
\end{tabular}

\subsection{Qualitative Factor Analysis}

The net benefit/cost (negative) associated with the excavation and off-site disposal of the radioactive soil at the HWMF ranged from $\$-64,484,330$ at $1 \mathrm{mrem} / \mathrm{yr}$ goal to $\$-15,928,460$ at the $100 \mathrm{mrem} / \mathrm{yr}$ limit. Therefore, this option is not a reasonable one to consider, based on net benefit alone, when evaluating various remedial alternatives to reduce potential radiological risk. However, facts relating to the costs, benefits, risks, and other societal, technical, and political considerations also must be considered by decision- 
makers. The types of qualitative factors that are typically considered in evaluating remedial alternatives at superfund sites (USEPA 1988b) are the following: Worker Health and Safety Risks; Public Health and Safety Risks; Environmental Risks; Community/Worker Concerns; Regulatory Compliance; Long-Term Effectiveness and Permanence; Reduction of Toxicity, Mobility, or Volume through Treatment; and Miscellaneous Concerns (see worksheet in Appendix J, Attachment 8 - Qualitative Factor Analysis). The results of this qualitative factor analysis results are summarized below.

1. Worker Health and Safety Risks: Exposure to other health risks (not quantified previously) by workers are not expected to be significant. Other hazardous substances are present at the HWMF, such as mercury and lead. Mercury concentrations at the former 445-3 underground storage tank (UST) were above the risk-based remediation goal for a child resident of $23 \mathrm{mg} / \mathrm{kg}$. One soil sample (boring $36 \mathrm{~A}=429 \mathrm{mg} / \mathrm{kg}$ ) was above the EPA lead-screening level of $400 \mathrm{mg} / \mathrm{kg}$ for soil ingestion using a residential scenario.

No Remedial Action: Workers who sample the HWMF monitoring wells could be exposed to the residual levels from these hazardous substances if no remedial actions were taken. However, the risk to present workers was considered minimal since the area that is contaminated is such a small fraction of the site.

With Remedial Action: Remedial workers' intakes of hazardous materials during remediation was considered minimal, since all involved are required to wear protective clothing and half-face respirators. If remedial action was taken, since the radionuclide concentration in this soil is above the DCGL value, this soil that also contains lead and mercury will be removed and the mixed waste disposed of off-site. Therefore, the risk to workers from hazardous substances would eventually be eliminated.

2. Public Health and Safety Risks: Exposure to other health risks (not quantified previously) by the public are not expected to be significant.

No Remedial Action: The public who may use this open-space site in future could be exposed to the residual levels from the hazardous substances (mercury and lead). However, the risk to future visitors was considered minimal since the area that is contaminated is such a small fraction of the site and little time is spent there.

With Remedial Action: As indicated in Section 2.2.3, exposure of the public to the fugitive dust during remedial actions was considered negligible. Public health and safety risks are expected to be minimal since only trace levels of the hazardous materials exist and only a small percentage of the area is contaminated. 
3. Environmental Risks: The environmental risks have the most significant uncertainty.

No Remedial Action: If no remedial action is taken, the radiological risks to the wildlife and the risk from hazardous chemicals is not well known. Since no national monuments or cultural artifacts exist at the HWMF site there are no impacts.

With Remedial Action: If remedial actions are taken in the HWMF wetlands, the potential damage to the wetlands and its impact on local wildlife is unknown. The remediation of the wetland habitat could affect the endangered tiger salamander. Because the HWMF wetlands are a sensitive habitat, timing of the remediation and other precautions will be taken to avoid disturbing the tiger salamander.

4. Community/Worker Concerns: Most BNL workers and the public are aware of the radioactive contamination at the HWMF.

No Remedial Action: If no remedial action is taken, both groups of stakeholders would be outraged.

With Remedial Action: If remedial actions are taken the concerns of BNL's workers, the public, and politicians would be appeased. The public and politicians appear to be endorsing the option of large-scale excavation and off-site disposal.

5. Regulatory Compliance: Remediation of the HWMF site is required by both Federal and State regulations. In addition, an interagency agreement has established the framework for the environmental restoration activities across the site. The U.S. Department of Energy (DOE) is required to comply with the terms and conditions of the associated Federal Facilities Agreement (Administrative Docket Number: IICERCLA - FFA-00201) which became effective in May 1992.

No Remedial Action: If no remedial action is taken, current legal suits could be jeopardized and additional suits could be filed. Litigation is currently being pursued via a class action suit for civil claims for damages from breast cancer. This suit has been filed with Suffolk County Court by residents from Mastic Beach and Shirley. NYS-DEC and USEPA have taken administrative actions against DOE due to the damage to a natural resource, namely, the sole-source aquifer. Additional liabilities in the range of millions of dollars could result.

With Remedial Action: If remedial actions are taken, the CERCLA rule in 40 CFR 300 , to remediate when individual lifetime cancer risks are greater than 1 in 10,000 will be complied with. In addition, the DOE rule 10 CFR 834 proposed public dose limit of $100 \mathrm{mrem} / \mathrm{yr}$ will also be complied with by excavation and disposal of the contaminated soil. The interagency agreement between DOE, EPA and NYS would be 
met, in part. This potential source of exposure could be argued as being minimal by the defense at trial.

6. Long-term Effectiveness and Permanence: This factor relates to the ability of the remedial action to produce an effective and permanent reduction in radiological and hazardous chemical risk.

No Remedial Action: If no remedial action is taken, effectiveness would be poor and the hazard would not be permanently removed.

With Remedial Action: If remedial actions are taken, very effective and permanent protection is afforded by excavation and disposal. Only minor leaching of residual radioactive material in the soil is expected to occur. Minimal residual risk is expected after the closure of BNL; the estimated dose from residual activity to the reasonable maximum-exposed person is expected to be much less than $15 \mathrm{mrem} / \mathrm{yr}$.

7. Reduction of Toxicity, Mobility, or Volume through Treatment: No decontamination, soil washing, recycling, or other treatments will be used as a part of the large scale excavation and off-site disposal option. Some treatment and recycle options were evaluated during the feasibility study but were not found to be cost-effective.

8. Miscellaneous Concerns: No impacts on personnel, facility operation, or other resources were expected. A new Hazardous Waste Storage Facility has been built to replace the function of the old HWMF before remediation begins. 


\subsection{SUMMARY AND CONCLUSIONS}

The Hazardous Waste Management Facility (HWMF) is one of the areas undergoing environmental remediation at Brookhaven National Laboratory (BNL). The BNL site was added to the National Priority List by the U.S. Environmental Protection Agency (EPA) on December 21, 1989. An interagency agreement was signed shortly thereafter which established the framework for the environmental restoration activities. This agreement states that DOE must comply with all applicable and relevant and appropriate requirements and regulations. This ALARA or risk optimization analysis was undertaken in accordance with the applicable requirements (USDOE 1991b \& USEPA 1988b) and DOE guidance (USDOE 1991 a \& 1997). It also was consistent, to the extent possible, with the relevant and appropriate requirements of NRC 10 CFR Part 20, Subpart $\mathrm{E}$, as well as the potential requirements in the available versions of proposed DOE $10 \mathrm{CFR}$ Part 834 (USDOE 1993), and draft EPA 40 CFR Part 196 (withdrawn by EPA on December 19, 1996).

For more than 20 years, the HWMF has been the facility for processing, limited treatment, and storage of radioactive and hazardous waste. Operations at this BNL facility are being terminated. A Feasibility Study was conducted in 1996 (CDM 1996b). The remedy selected in this draft report was large-scale excavation with off-site disposal. This involved excavating $30,800 \mathrm{yd}^{3}\left(24,000 \mathrm{~m}^{3}\right)$ in order to achieve the preliminary remediation goal of $67 \mathrm{pCi} / \mathrm{g}$ for cesium-137. This cleanup goal was based on a 15 $\mathrm{mrem} / \mathrm{yr}$ dose goal using a commercial industrial scenario and 50 years of Federal control.

In this risk assessment/optimization analysis, the derived concentration guideline limits (DCGLs) was based on a range of cleanup goals from $1 \mathrm{mrem} / \mathrm{yr}$ to $100 \mathrm{mrem} / \mathrm{yr}$ using an open-space scenario and 50 years of Federal control. Approximately, 8,000 $\mathrm{yd}^{3}$ to $78,000 \mathrm{yd}^{3}\left(6,000 \mathrm{~m}^{3}\right.$ to $\left.60,000 \mathrm{~m}^{3}\right)$ of contaminated soil would require excavation in order to achieve the corresponding DCGLs of $15 \mathrm{pCi} / \mathrm{g}$ to $1,500 \mathrm{pCi} / \mathrm{g}$. The remedy in the attached report assumed packaging it into B-25 steel containers, storing them temporally at the new HWMF, and transporting and disposing of the low-level waste at the Envirocare disposal site in Clive, Utah, and the stabilized waste at the Fluor Daniels disposal site in Richland, Washington. This report estimated the risks averted to the workers and members of the public from this assumed remedy.

Also, two types of dose assessment methodologies were developed to ascertain whether the proposed criteria from EPA's Radiation Site Cleanup Rule (1996 proposed 40 CFR 196, but withdrawn by EPA from consideration by OMB on December 19, 1997) would be met. One of these analysis included for a restricted release alternative, derived secondary concentration guidelines associated with the failure of active controls. The second, was an evaluation of potential groundwater impacts separate from the all other pathways. In addition, other risks to workers and the public were considered and assessed, such as hazardous chemical risk to workers during excavation, fatalities resulting 
from transporting the contaminated soil, and construction fatalities due to excavating, backfilling, and packaging.

To make an informed decision about remediating this contaminated site, the net benefit of the large-scale excavation and off-site disposal was calculated for the various risk-based remediation goals and the limit. In addition, a qualitative factor analysis was performed to provide decision-makers with other societal, technical, and political factors needed to make an informed choice.

\subsection{Results of Risk Assessments}

Dose assessments were made for workers and the public to determine the risk to be averted from this proposed remedial action. The risk-based remediation goals that were used to assess these doses were $1,15,25,75$, and the $100 \mathrm{mrem} / \mathrm{yr}$ limit. These goals and limit translated into the DCGL listed in Table 4.1-1. They were based on an undeveloped open-space scenario and the 50 years of federal control.

Table 4.1-1. Derived Concentration Guideline Limits (DCGL) for Undeveloped Open-Space Equivalent to $15 \mathrm{mrem} / \mathrm{yr}$ after 50 Years of Federal Control

\begin{tabular}{|c|c|c|}
\hline $\begin{array}{c}\text { Risk-Based } \\
\text { Remediation Soil } \\
\text { Cleanup Goals/Limit } \\
\text { (mrem/yr) }\end{array}$ & $\begin{array}{c}\text { DCGL } \\
\text { Cesium-137 } \\
\text { (pCi/g) }\end{array}$ & $\begin{array}{c}\text { DCGL } \\
\text { Strontium-90 } \\
\text { (pCi/g) }\end{array}$ \\
\hline 1 & 15 & 390 \\
\hline 15 & 230 & 5,800 \\
\hline 25 & 380 & 10,000 \\
\hline 75 & 1,140 & 29,000 \\
\hline 100 & 1,500 & 39,000 \\
\hline
\end{tabular}

These goals required that the following soil volumes be excavated: $78,000 \mathrm{yd}^{3}$ $\left(60,000 \mathrm{~m}^{3}\right) ; 26,000 \mathrm{yd}^{3}\left(20,000 \mathrm{~m}^{3}\right) ; 20,000 \mathrm{yd}^{3}\left(15,000 \mathrm{~m}^{3}\right) ; 9,000 \mathrm{yd}^{3}(7,000$ $\left.\mathrm{m}^{3}\right)$; and $8,000 \mathrm{yd}^{3}\left(6,100 \mathrm{~m}^{3}\right)$, respectively. The resulting volume-weighted geometric average concentrations and volume-weighted arithmetic average concentrations for cesium-137 and strontium-90 that were used for the dose assessments are listed in Appendix C. 
The estimated range of collective doses for workers, over the remediation $\mathrm{goal} /$ limit range of 1 to $100 \mathrm{mrem} / \mathrm{yr}$, are summarized below. The potential radiation doses to workers resulting from excavation and off-site disposal would be extremely large in comparison to the potential radiation dose that would be saved by remediation.

- Worker collective dose savings from remediation: 4.1 to 3.8 person-rem

- Worker collective dose impacts from remediation: -223 to -212 person-rem

- Net collective dose to workers: -219 to -208 person-rem

The estimated range of collective doses for the future public, over the remediation goal/limit range of 1 to $100 \mathrm{mrem} / \mathrm{yr}$, are summarized below. The potential radiation doses to the public resulting from excavation and off-site disposal (collective dose impacts) would be about three times greater than the potential radiation dose that would be avoided by remediation (net collective dose). The radiological impacts to the public from the remediation (dose impacts from remediation) would be comparable to the dose that would be saved (dose savings from remediation). Workers would receive about 100 times more collective dose than what would be averted to the public.

- Public collective dose savings from remediation: 8.5 to 8.1 person-rem

- Public collective dose impacts from remediation: -6.7 to -6.3 person-rem

- $\quad$ Net collective dose to public: 1.8 to 1.8 person-rem

Next, the risks from both radiological and other hazards were assessed. To estimate the hypothetical radiation risks to workers, the net collective doses to workers were multiplied by a worker risk factor of $4 \times 10^{-4}$ cancer fatalities per rem taken from International Commission on Radiological Protection's (ICRP's) report 60. Hypothetical radiation risks to the public were estimated using their public risk factor, $5 \times 10^{-4}$ cancer fatalities per rem (ICRP 1991). Worker construction risks were estimated by converting worker's labor hours to construction fatalities using a factor of $4.2 \times 10^{-8}$ fatal injuries per hour (USNRC 1994). Transport risks were estimated by converting the total mileage for the waste shipments to transportation fatalities using a factor of $4 \times 10^{-9}$ occupant deaths per heavy truck mile (USDOT 1994). The hypothetical fatalities for workers and public from radiological causes, construction, and transportation fatalities at the various remediation goals are summarized in Table 4.1-2. They show that the net risk of fatalities associated with remediation range from 15 in 100 , to 9 in 100 for the remediation goal/limit of 1 and $100 \mathrm{mrem} / \mathrm{yr}$, respectively. Therefore, the probability for a hypothetical fatality resulting from remedial actions ( 9 in 100 to 15 in 100 hypothetical fatalities) are higher than that for the no action alternative ( 1 in 10,000 to 43 in 10,000 hypothetical fatalities). 
Table 4.1-2 Estimated Hypothetical Fatalities Associated with Remediation

\begin{tabular}{|c|c|c|c|c|c|}
\hline $\begin{array}{c}\text { Risk-based } \\
\text { Remediation } \\
\text { Goals/Limit } \\
\text { (mrem/yr) }\end{array}$ & $\begin{array}{c}\text { Net Worker } \\
\text { Radiation } \\
\text { Fatalities }\end{array}$ & $\begin{array}{c}\text { Net Public } \\
\text { Radiation } \\
\text { Fatalities }\end{array}$ & $\begin{array}{c}\text { Worker } \\
\text { Construction } \\
\text { Fatalities }\end{array}$ & $\begin{array}{c}\text { Transport } \\
\text { Fatalities }\end{array}$ & $\begin{array}{c}\text { Net } \\
\text { Hypothetical } \\
\text { Fatalities }\end{array}$ \\
\hline \hline 1 & 0.0876 & -0.00093 & 0.0040 & 0.0600 & 0.1506 \\
\hline 15 & 0.0856 & -0.00097 & 0.0010 & 0.0200 & 0.1056 \\
\hline 25 & 0.0856 & -0.00097 & 0.0010 & 0.0160 & 0.1016 \\
\hline 75 & 0.0836 & -0.00096 & 0.0005 & 0.0080 & 0.0912 \\
\hline 100 & 0.0832 & -0.00093 & 0.0004 & 0.0070 & 0.0897 \\
\hline
\end{tabular}

NRC's 10 CFR Part 20 (USNRC 1997) contains a requirement to assess potential doses under restricted use scenarios assuming the restrictions fail. NRC's rule has a $100 \mathrm{mrem}$ in a year constraint for such an event. EPA draft 40 CFR Part 196 included a similar constraint but originally employed $75 \mathrm{mrem}$ in a year rather than $100 \mathrm{mrem}$ in a year. The later EPA proposed rule suggested $85 \mathrm{mrem}$ in a year; this proposed rule for Radiation Site Cleanup was later withdrawn by EPA from consideration by OMB on December 19,1996. An analysis was conducted to estimate the dose to a resident assuming the failure of active institutional controls (section 2.3) to establish alternate derived-concentration guidelines for comparison. The $75 \mathrm{mrem}$ in a year dose constraint was used because it represented the most restrictive of the existing, proposed or draft requirements; it's selection was also based on DOE's radiation limit for the public of $100 \mathrm{mrem} / \mathrm{yr}$ with a $25 \mathrm{mrem} / \mathrm{yr}$ safety margin. This 25 $\mathrm{mrem} / \mathrm{yr}$ safety margin was based on the NCRP's prospective single-source dose constraint. The value of the alternate derived-concentration guideline for the loss of active controls for cesium- 137 was $500 \mathrm{pCi} / \mathrm{g}$ ( $75 \mathrm{mrem} / \mathrm{y}$ to a basement occupant). This is less restrictive than the value of $230 \mathrm{pCi} / \mathrm{g}$ calculated using the $15 \mathrm{mrem} / \mathrm{yr}$ EPA proposed guideline, 50 years of federal control, and undeveloped open-space scenario. However, the alternate derived concentration guideline for strontium-90, that is equivalent to this $75 \mathrm{mrem} / \mathrm{yr}$ criterion, is more restrictive than that based on the $15 \mathrm{mrem} / \mathrm{yr}$ EPA's proposed criterion ( $300 \mathrm{pCi} / \mathrm{g}$ vs. $5,800 \mathrm{pCi} / \mathrm{g}$ ). Therefore, the strontium- 90 alternate derived concentration guideline for the loss of active controls should be considered in the selecting the final remediation goal.

The second method compared the measured and the projected concentrations in groundwater (Section 2.4) to EPA's Primary Drinking Water Regulations. Groundwater modeling simulated future migration of the current concentrations of strontium-90. These concentrations were compared against the EPA Maximum Contaminant Level (MCL) of $8 \mathrm{pCi} / \mathrm{L}$ to determine if they were, or will be, exceeded. The MCL for strontium-90 was exceeded in monitoring wells on-site, but not off-site. 
The draft EPA 40 CFR Part 196 contained a requirement to determine if the Primary Drinking Water Regulations would be exceeded in the present or future. Accordingly, soil-to-water concentration guidelines were calculated, an alternate remediation goal of $45 \mathrm{pCi} / \mathrm{g}$ was derived for strontium-90 using the New York State methodology for deriving screening levels, but it was based on the maximum groundwater concentration measured during the 1994 to 1995 OU I remedial investigation program (CDM 1996b). An analysis was conducted to derive the residual radionuclide concentration in soil so that off-site concentrations in groundwater would not be expected to exceed the EPA's safe drinking water standard over the next 1,000 years. However, this alternate derived- concentration guideline for strontium-90, that is equivalent to the EPA drinking water standard, was more restrictive than that based on $15 \mathrm{mrem} / \mathrm{yr}$, EPA's proposed criteria ( $45 \mathrm{pCi} / \mathrm{g}$ vs. 5,800 $\mathrm{pCi} / \mathrm{g}$ ). Therefore, the strontium-90 alternate derived-concentration guideline for demonstrating compliance with EPA's Primary Drinking Water Regulation should be considered in selecting the final remediation goal.

\subsection{Results of Risk Optimization Analysis}

A decision-making tool (a software application) developed at the BNL ALARA Center called Radiological Assessment \& Design System (RADS) Version 2.0 was used for optimization/ALARA analysis. The net-benefit module determines if a protective measure or, in this case, the remedial action that reduces radiation exposure is reasonably achievable or ALARA. This process involved calculating the cost savings from the remedial action, the life cycle costs for the remedial action, the value of the net dose avoided, and the value of other avoided risks and damages. The results for the net-benefit analysis using the $15 \mathrm{mrem} / \mathrm{yr}$ remediation goal (see Appendix J, Attachment 7) were as follows:

1) Cost of excavation and disposal

2) Benefits from reduced well sampling and potential real-estate sale

3) Value of collective dose averted or expended (negative)

4) Value of avoided risks and damages

Net Benefit or Cost (negative)

$$
\$-28,650,610
$$$$
\$ \quad 819,000
$$$$
\$ \quad-424,000
$$$$
\$ \quad 27,640
$$

$\$-28,227,970$

Table 4.2-1 lists the net benefits for the various remediation goals/limits. Based on risk avoidance and economic factors alone, it was concluded that, neither of these goals were reasonably achievable since no net benefit would be achieved below $100 \mathrm{mrem} / \mathrm{yr}$. 
Table 4.2-1 Net Benefit or Costs at Various Remediation Goals/Limit

\begin{tabular}{|c|c|}
\hline $\begin{array}{c}\text { Risk-based Remediation } \\
\text { Goals/Limit } \\
\text { (mrem/yr) }\end{array}$ & $\begin{array}{c}\text { Net Benefit/Cost } \\
\text { (1997 Dollars) }\end{array}$ \\
\hline 1 & $\$-64,486,330$ \\
\hline 15 & $\$-28,227,970$ \\
\hline 25 & $\$-24,386,860$ \\
\hline 75 & $\$-16,618,970$ \\
\hline 100 & $\$-15,930,460$ \\
\hline
\end{tabular}

Next, we considered the societal, technological, and political factors. However, since the DOE public radiation dose limit in the proposed 10 CFR 834 is $100 \mathrm{mrem} / \mathrm{yr}$ and the EPA Comprehensive Environmental Response, Compensation, and Liability Act (Superfund) regulatory risk range for remedial action is one in ten thousand to one in a million, whatever costs are needed to comply with these Federal rules must be expended. The decision-makers must therefore decide at what level below these regulatory levels is reasonable based on the net benefit and the other societal and political factors.

The other societal and political factors to be considered for the selection of the optimal level for BNL's HWMF remediation are summarized below.

1. Worker Health and Safety Risks: If no remedial action was taken, the workers who now sample the HWMF monitoring wells, and in future, could be exposed to the residual levels from lead and mercury. However, the risk to present workers was considered minimal, since the area that is contaminated is such a small fraction of the site that exposures are unlikely.

If remedial action is taken, the risk estimated to remedial workers from mercury and lead was considered to be minimal, since all such workers are required to wear protective clothing and half-face respirators. The mixed waste will be disposed of on-site or off-site. Therefore, worker health and safety risks from the mercury and lead would be essentially eliminated.

2. Public Health and Safety Risks: If no remedial action was taken, the public who may use this open-space site in the future could be exposed to the residual levels from the hazardous substances (mercury and lead). However, the risk to future visitors was considered minimal since the area that is contaminated is such a small fraction of the site and little time is spent there. 
If remedial action is taken, exposure of the public to the fugitive dust during remedial actions was considered negligible. However, public health and safety risks are expected to be minimal since only trace levels of the hazardous materials exist and only a small percentage of the area is contaminated.

3. Environmental Risks: If no remedial action is taken, the radiological risks to the wildlife and the risk from hazardous chemical is not really well known. Since no national monuments or cultural artifacts exist at the HWMF site there are no impacts.

If remedial actions are taken in the HWMF wetlands, the potential damage to the wetlands and its impact on local wildlife is unknown. Remediation of the wetland habitat could impact the endangered tiger salamander. Because the HWMF wetlands is a sensitive habitat, timing of the remediation and other precautions are being considered to avoid disturbing the tiger salamander.

4. Community/Worker Concerns: If no remedial action is taken, all groups of stakeholders, mainly the politicians, workers and public would be outraged.

If remedial actions are taken the concerns of BNL's workers, the public and possibly the politicians would be appeased. The public and politicians appear to be endorsing the option of large-scale excavation and off-site disposal.

5. Regulatory Compliance: If no remedial action is taken, current legal suits could be jeopardized and additional suits could be filed. Litigation is currently being pursued via a class action suit for civil claims for damages from breast cancer. This suit has been filed with Suffolk County Court by residents from Mastic Beach and Shirley. NYS-DEC and USEPA have taken administrative actions against DOE due to the damage to a natural resource, namely, the solesource aquifer. Enforcement actions are also expected. Additional liabilities in the range of millions of dollars could result.

If remedial actions are taken, regulatory compliance with the CERCLA rule in 40 CFR 300 will be achieved i.e., to remediate when individual lifetime cancer risks are of the order of 1 in 10,000 to 1 in 1,000,000. In addition, the DOE 10 CFR 834 proposed public dose limit and NRC's relevant and appropriate requirement of $100 \mathrm{mrem} / \mathrm{yr}$ will also be complied with if excavation and disposal were carried out. The interagency agreement between DOE, EPA and NYS would be met, in part. This potential source of exposure could be argued as being minimal by the defense at trial. However, the damage to the aquifer although reduced by soil remediation would not be minimized or eliminated. Consequently, 
fines, enforcement actions and administrative orders could still be pursued for the damages to the sole source aquifer.

6. Long-term Effectiveness and Permanence: If no remedial action is taken, effectiveness would be poor and the hazard would not be permanently removed.

If remedial actions are taken, very effective and permanent protection is afforded by excavation and disposal. Only minor leaching of residual radioactive material in the soil is expected to occur. Minimal residual risk is expected after the closure of BNL; the estimated dose from residual activity to the reasonable maximum-exposed person is expected to be much less than $15 \mathrm{mrem} / \mathrm{yr}$.

7. Reduction of Toxicity, Mobility, or Volume through Treatment: No decontamination, soil washing, recycling, or other treatments will be used as a part of the large-scale excavation and off-site disposal option. Some treatment and recycle options were evaluated during the feasibility study but were not found to be cost-effective.

8. Miscellaneous Concerns: No impacts on personnel, facility operation, or other resources were expected. A new Hazardous Waste Storage Facility has been built to replace the old HWMF before remediation begins.

\subsection{Conclusion}

In conclusion, we determined the volume of soil, which is a surrogate for the costs to remediate and hypothetical fatalities, over the range of measured radionuclide concentrations, which is a surrogate for radiological risks. We also examined and documented other societal and political factors. Since we have defined the optimum (ALARA) level as the point where the remediation costs and fatalities increase dramatically, it can be seen from Figure 4.3-1 that the cost/fatalities estimates increased dramatically below the $230 \mathrm{pCi} / \mathrm{g}$ (cesium-137) or the $15 \mathrm{mrem} / \mathrm{yr}$ risk-based remediation goal. By comparison the soil cleanup goal that was proposed by DOE to NYS and EPA was $67 \mathrm{pCi} / \mathrm{g}$ (cesium-137). Therefore, the planned soil cleanup level, which is based on the commercial industrial scenario, is more protective for the hypothetical future user than the level derived in this report using risk-based decision techniques.

The corresponding derived concentration guideline for strontium-90 was $5,800 \mathrm{pCi} / \mathrm{g}$ using risk-based decision techniques. An alternate analysis was performed to derive a soil to water cleanup guideline for strontium 90 that would assure protection of groundwater. This was needed since strontium 90 leaches more quickly through the soil than cesium-137 and thus must also be controlled to 
protect the sole-source aquifer. However, the value of the alternate derived concentration guideline to demonstrate compliance with the maximum concentration level in the EPA's Primary Drinking-Water Regulation was $45 \mathrm{pCi} / \mathrm{g}$ for strontium-90. As was the case with cesium-137, the preliminary remediation guideline that was proposed by DOE to the State and Federal regulators for strontium-90 was lower, in this case $15 \mathrm{pCi} / \mathrm{g}$. Therefore, the $15 \mathrm{pCi} / \mathrm{g}$ preliminary remediation guideline for the HWMF was more protective for the hypothetical future user than the level derived in this report using risk-based decision techniques.

The projected costs for excavation and offsite disposal as estimated in the draft Feasibility Study (CDM 1996b) was $\$ 38$ million. By contrast, the estimated cost to cleanup to the level derived in this report using risk-based decision techniques was about $\$ 28$ million. These lower remediation guidelines will result in an additional $\$ 10$ million being expended to remediate to the level that is expected to be selected by the State and Federal regulators. The benefits from these lower guidelines include reduction in risk to future visitors, in risk to potential residents if active controls fail, in residual radioactive material in soil, and in radioactive leachate that could contaminate the sole-source aquifer.

Figure 4.3-1 Optimization of Protection Costs and Hypothetical Fatalities at BNL's Hazardous Waste Management Facility

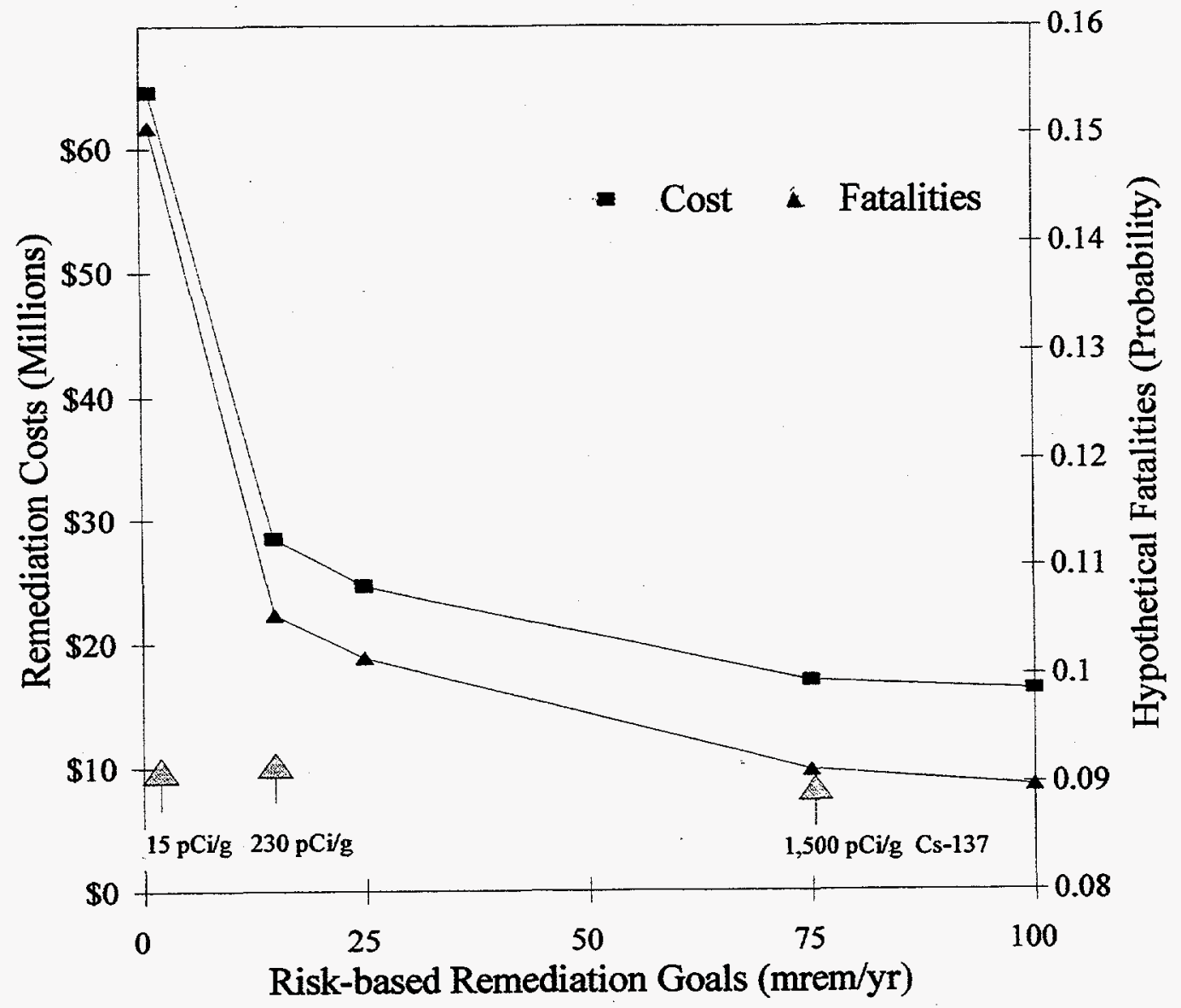




\subsection{REFERENCES}

ANL 1993a Manual for Implementing Residual Radioactive Material Guidelines Using RESRAD, Version 5.0. ANL/EAD/LD-2. Argonne National Laboratory, Environmental Assessment Division. September 1993.

ANL 1993b Data Collection Handbook to Support Modeling the Impacts of Radioactive Material in Soil. ANL/EAIS-8. Argonne National Laboratory, Environmental Assessment and Information Sciences Division. September 1993.

ANL 1994 Derivation of Residual Radioactive Material Guidelines for 13 Radionuclides Present in Operable Unit IV at Brookhaven National Laboratory, Upton, New York. ANL/EAD/TM-34. Argonne National Laboratory, Environmental Assessment Division. December 1994.

ANL 1995 Derivation of Residual Radioactive Material Guidelines in Soil for 13 Radionuclides Present at Brookhaven National Laboratory, Upton, New York. Revised Draft. Argonne National Laboratory, Environmental Assessment Division. August 1995.

Baes 1983 A Proposal for Estimation of Soil Leaching and Leaching Constants for Use in Assessment Models. Baes, C. F. and R. D. Sharp. Journal of Environment, 12(1):17-28. 1983.

BNL 1971-95 Brookhaven National Laboratory Site Environmental Reports. Brookhaven National Laboratory, Safety and Environmental Protection Division. 19711995.

BNL 1995 Brookhaven National Laboratory Future Use Plan. Brookhaven National Laboratory. BNL-62130. August 31, 1995.

CDM 1991 In-Situ Soil Stripping Treatability Study for the SMS Instrument, Inc., Deer Park, New York. Camp, Dresser and Mc Kee (CDM). May 1991.

CDM 1995a Brookhaven National Laboratory Operable Unit Groundwater Pre-Design Services. CDM Federal Programs Corporation. December 1, 1995.

CDM 1995b Brookhaven National Laboratory Final Report Engineering Evaluation/Cost Analysis for Ground Water Operable Unit I, Volume 1, Appendix A. CDM Federal Programs Corporation, September 15, 1995.

CDM 1996a Brookhaven National Laboratory, Revised 30\% Design Submission for Groundwater Removal Action V for Operable Unit I. CDM Federal Programs 
Corporation. May 3, 1996.

CDM 1996b Brookhaven National Laboratory Draft Feasibility Study- Operable Unit I: Sitewide Soil. CDM Federal Programs Corporation. September, 1996.

Cohen 1994 EPA Radiation Site Cleanup Regulations Technical Support Document: Volume I Methods for the Development of Radionuclide Soil Cleanup Levels. Cohen \& Associates. March 1994.

Davis 1995 Letter from M. Davis, Brookhaven National Laboratory, to H. Knoch, New York State Department of Environmental Conservation. May 15, 1995.

Dionne 1994 Brookhaven National Laboratory, Radiological Assessment and Design System Version 1.0 Users' Manual. Dionne, B.J., March 1994.

Dionne 1995 Memorandum to File, Radiation Survey of Hazardous Waste Management Facility's Monitoring Wells. Dionne, B.J. November 13, 1995.

Dionne 1997 Memorandum to File. Re: Radiation Survey of Hazardous Waste Management Facility's Perimeter Fence. Dionne, B.J. January 31, 1997.

Fuhrmann 1995 Memorandum to J. Brower f rom Mark Fuhrmann. Re: Kd Values for Uranium. April 11, 1995.

Fuhrmann 1996 Memorandum to J. Brower from Mark Fuhrmann. Re: Kd Values for Cesium, Strontium, Technetium, Radium, and Uranium. December 10, 1996.

Griego1996 Investigation of RADTRAN Stop Model Input Parameters for Truck Stops. Griego, N.R., J.D. Smith and K.S. Neuhauser. Sandia National Laboratory. Published in the Proceedings from the DOE Waste Management 96 Conference, Tucson, Arizona. 1996.

Grove 1995 Microshield Version 4.21 User's Manual. Grove Engineering, Rockville, MD. 1995.

Grove 1996 Microshield Version 5.00 User's Manual. Grove Engineering, Rockville, MD. 1996.

Guen 1997 Estimated Cost of Person-Sv Exposure. Guenther, C.F. and C. Thein. Health Physics, Vol. 72, No. 2. 1997.

ICRP 1987 Data for Use in Protection Against External Radiation. ICRP Publication 51. International Commission on Radiological Protection. 1987. 
ICRP 19911990 Recommendations of the International Commission on Radiological Protection. ICRP Publication 60. International Commission on Radiological Protection. 1991.

Lagatolla 1996 Personal communication, R. Lagatolla with B. Dionne. August 1996.

Meinhold 1997 Deriving Soil Cleanup Guidelines for Radionuclides at Brookhaven National Laboratory. Informal Report. BNL-64217. Meinhold, A.F., S.C. Morris, B.J. Dionne, and P.D. Moskowitz, Brookhaven National Laboratory. January 1997.

Nagle 1975 Climatology of Brookhaven National Laboratory 1949 through 1973. BNL50466. Nagle, C.M., Brookhaven National Laboratory. November 1975.

Nagle 1978 Climatology of Brookhaven National Laboratory 1974 through 1977. BNL50857. Nagle, C.M., Brookhaven National Laboratory. May 1978.

NCRP 1987 Recommendations on Limits for Exposure to Ionizing Radiation. NCRP Report 91. National Council on Radiation Protection and Measurements, Bethesda, MD. 1987.

Norton 1997 Personal communication. J. Norton, American Stone-Mix, Inc of Towson, MD, with B. Dionne. March 19, 1997.

NYS 1995 Technical Administrative Guideline Memorandum 4046, Determination of Soil Cleanup Objectives and Cleanup Levels. New York State Department of Environmental Conservation. September 1995.

Sheppard 1990 Default Soil Solid/Liquid Partition Coefficients, $\mathrm{K}_{\mathrm{d}}$ for Four Major Soil Types: A Compendium. Sheppard, M.I. and D.H. Thibault. Health Physics, Volume 59, Number 4. October 1990.

USDOE 1991a DOE Guidance on the Procedures in Applying the ALARA Process for Compliance with DOE 5400.5, Interim Guidance. United States Department of Energy. 1991.

USDOE 1991b Radiation Protection of the Public and the Environment. DOE Order 5400.5. United States Department of Energy. 1991

USDOE 1993 Radiation Protection of the Public and the Environment: Notice of Proposed Rulemaking. United States Department of Energy. Published in Federal Register 58 FR 16268. March 1993. 
USDOE 1997 DOE Standard-Applying the ALARA Process for Radiation Protection of the Public and the Environmental Compliance with 10 CFR Part 834 and DOE 5400.5 ALARA Program Requirements. DOE-STD-ALARA1 and ALARA2 (draft). United States Department of Energy. April 1997.

USDOT 1994 Traffic Safety Facts - National Traffic Administration Traffic Accident Data. DOT HS 808 169. United States Department of Transportation. October 1994.

USEPA 1976 National Interim Primary Drinking Water Regulations. EPA-570/9-76-003, United States Environmental Protection Agency, Washington, D.C. 1976.

USEPA 1977 Environmental Radiation Protection Standards for Nuclear Power Operations Final Rule. Published in Federal Register 42 FR 2860. United States Environmental Protection Agency. January 1977.

USEPA 1985 Compilation of Air Pollutant Emission Factors, Volume I. Stationary Point and Area Sources. United States Environmental Protection Agency. AP-42. 1985.

USEPA 1988a Federal Guidance Report No. 11 - Limiting Values of Radionuclide Intake and Air Concentration and Dose Conversion Factors for Inhalation, Submission and Ingestion. EPA 520/1-88-020. United States Environmental Protection Agency, Office of Air and Radiation. September 1988.

USEPA 1988b 1990 National Contingency Plan, proposed revisions to 40 CFR 300, Subpart E. United States Environmental Protection Agency. Published in Federal Register, 53 FR1422. Washington, D.C. December 1988.

USEPA 1991 National Primary Drinking Water Regulations: Radionuclides, Notice of Proposed Rulemaking. United States Environmental Protection Agency. Published in Federal Register 56 FR138, Washington, D.C. February 1991.

USEPA 1992 User's Guide for CAP88-PC Version 1.0. EPA-402-B-92-001. United States Environmental Protection Agency, Office of Radiation Programs. March 1992.

USEPA 1993a Federal Guidance Report No. 12 - External Exposure to Radionuclides in Air, Water and Soil. EPA 402-R-93-081. United States Environmental Protection Agency, Office of Air and Radiation. September 1993.

USEPA 1993b Federal Radiation Protection Guidance for Exposure of the General Public Notice. United States Environmental Protection Agency. Published in 
Federal Register 59 FR 66414. December 1993.

USEPA 1995 Draft Regulatory Impact Analysis Radiation Site Cleanup Regulation, Volume I, Review Summary (Preliminary Staff Working Draft). United States Environmental Protection Agency. Published in Federal Register 58 FR 54474. 1995.

USEPA 1996 Soil Screening Guidance: Technical Background Document and Soil Screening Guidance: User Guide. United States Environmental Protection Agency. 1996.

USGS 1975 Soil Survey of Suffolk County, New York. United States Department of Agriculture Soil Conservation Service, Washington, D.C. April 1975.

USGS 1992 Rates of Water Movement Through the Floors of Selected Stormwater Basins in Nassau County, Long Island, New York. United States Geological Survey Water Resources Investigations Report 91-4012. 1992.

USNRC 1976 Acceptable Programs for Respiratory Protection. United States Nuclear Regulatory Commission. Regulatory Guide 8.15. 1976

USNRC 1982 Requirements for Land Disposal of Radioactive Waste, Final Rule. United States Nuclear Regulatory Commission. Published in Federal Register 47 FR 248. December 1982.

USNRC 1990 Occupational Radiation Protection, Final Rule. United States Nuclear Regulatory Commission. Published in Federal Register 56 FR 23350. May 1991.

USNRC 1992 Residual Radioactive Contamination from Decommissioning - Technical Basis for Translating Contamination Levels to Annual Total Effective Dose Equivalent. NUREG/CR-5512. Prepared by Battelle Pacific Northwest Laboratories for the United States Nuclear Regulatory Commission. October 1992.

USNRC 1993 Site Decommissioning Management Plan. United States Nuclear Regulatory Commission, Division of Low-level Waste Management and Decommissioning. NUREG-1444. 1993.

USNRC 1995 Regulatory Analysis Guidelines of the United States Nuclear Regulatory Commission, Final Report. NUREG/BR-0058, Rev. 2. November 1995.

USNRC 1997 Final Rule on Radiological Criteria for License Termination, Letter from L. 
Joseph Callen to the United States Nuclear Regulatory Commission's Commissioners dated March 28, 1997, SECY-97-046A (includes Generic

Environmental Impact Statement. NUREGR-1496, Vols. 1 \& 2, July 1997)

Utah 1995 Utah Department of Environmental Quality, Division of Radiation Control, Radioactive Material License \#UT 2300249, DRC-04-8/89, 1995.

Warren 1968 Hydrology of Brookhaven National Laboratory and Vicinity, Suffolk County, New York. Warren, M.A., De Laguna, W. and Lusczynski, N.J. 1968.

WHC 1995 Westinghouse Hanford Company's Waste Acceptance Criteria Manual, WHCEP-0063-4, Westinghouse Hanford Company. 1995.

Williams 1995 Comments on draft report entitled Derivation of Residual Radioactive Material Guidelines for 13 Radionuclides Present in Operable Unit IV at Brookhaven National Laboratory, Upton, New York. W. Alexander Williams Letter to Charley Yu dated May 10,1995

Wolbarst 1996 Technical Basis for EPA's Proposed Regulations on the Cleanup of Sites Contaminated with Radioactivity. Wolbarst, A.B., et al. Health Physics, Vol. 71, No. 5. November 1996 